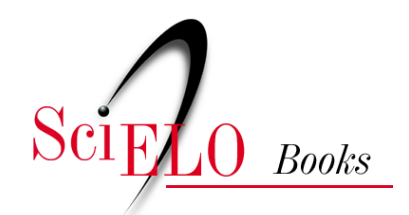

\title{
A história da educação em manuscritos, periódicos e compêndios do XIX e XX
}

\author{
Edgleide de Oliveira Clemente da Silva \\ Ivanildo Gomes dos Santos \\ Suzana Lopes de Albuquerque \\ (orgs.)
}

SILVA, E.O.C., SANTOS, I.G. and ALBUQUERQUE, S.L., orgs. A história da educação em manuscritos, periódicos e compêndios do XIX e XX [online]. Rio de Janeiro: EdUERJ, 2018, 139 p. ISBN 978-85-7511-483-4. https://doi.org/10.7476/9788575114834.

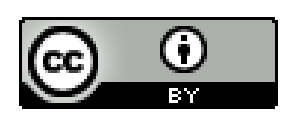

All the contents of this work, except where otherwise noted, is licensed under a Creative Commons Attribution 4.0 International license.

Todo o conteúdo deste trabalho, exceto quando houver ressalva, é publicado sob a licença Creative Commons Atribição $\underline{4.0}$.

Todo el contenido de esta obra, excepto donde se indique lo contrario, está bajo licencia de la licencia $\underline{\text { Creative Commons }}$ $\underline{\text { Reconocimento 4.0. }}$. 
A história da Educação em manuscritos, periódicos e compêndios do XIX e XX 
UNIVERSIDADE DO ESTADO DO RIO DE JANEIRO

Reitor

Ruy Garcia Marques

Vice-reitora

Maria Georgina Muniz Washington

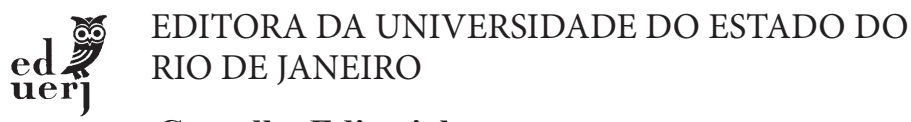

Conselho Editorial

Glaucio José Marafon (presidente)

Henriqueta do Coutto Prado Valladares

Hilda Maria Montes Ribeiro de Souza

Italo Moriconi Junior

José Ricardo Ferreira Cunha

Lucia Maria Bastos Pereira das Neves

Luciano Rodrigues Ornelas de Lima

Maria Cristina Cardoso Ribas

Tania Maria Tavares Bessone da Cruz Ferreira

Anibal Francisco Alves Bragança (EDUFF)

Katia Regina Cervantes Dias (UFRJ) 


\section{Edgleide de Oliveira Clemente da Silva}

Ivanildo Gomes dos Santos

Suzana Lopes de Albuquerque

(orgs.)

\section{A história da Educação em manuscritos, periódicos e compêndios do $\mathrm{XIX}$ e $\mathrm{XX}$}

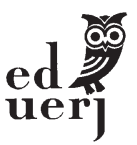

Rio de Janeiro

2018 
Copyright (c) 2018, os autores.

Todos os direitos desta edição reservados à Editora da Universidade do Estado do Rio de Janeiro. É proibida a duplicação ou reprodução deste volume, ou de parte do mesmo, em quaisquer meios, sem autorização expressa da editora.

\section{EdUERJ}

Editora da UNIVERSIDADE DO ESTADO DO RIO DE JANEIRO

Rua São Francisco Xavier, 524 - Maracanã

CEP 20550-013 - Rio de Janeiro - RJ - Brasil

Tel./Fax.: 55 (21) 2334-0720 / 2334-0721

www.eduerj.uerj.br

eduerj@uerj.br

Editor Executivo

Coordenadora Administrativa

Coordenadora Editorial

Assistente Editorial

Coordenador de Produção

Supervisor de Revisão

Revisão

Capa

Projeto Gráfico

Diagramação
Glaucio Marafon

Elisete Cantuária

Silvia Nóbrega

Thiago Braz

Mauro Siqueira

Elmar Aquino

Elmar Aquino

João Martorelli

Júlio Nogueira

Editora Morandi

Editora Morandi

CATALOGAÇÃO NA FONTE

UERJ/REDE SIRIUS/NPROTEC

H673 A história da educação em manuscritos, periódicos e compêndios do XIX e XX / Edgleide de Oliveira Clemente da Silva, Ivanildo Gomes dos Santos, Suzana Lopes de Albuquerque, orgs. - Rio de Janeiro : EdUERJ, 2018. $144 \mathrm{p}$.

ISBN 978-85-7511-483-4

1. Educação - História - Séc. XIX. 2. Educação - História - Séc. XX.

I. Silva, Edgleide de Oliveira Clemente da. II. Santos, Ivanildo Gomes dos. III. Albuquerque, Suzana Lopes de.

CDU 37(091)“18/19” 


\section{SUMÁRIO}

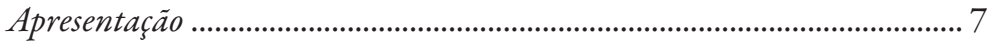

Carlota Boto

Prefácio: (Des)alinhando expectativas em torno de manuscritos

e impressos alagoanos

José G. Gondra

A instrução nas Alagoas no período colonial: os manuscritos e os primeiros vestígios de uma educação não dirigida por religiosos

Ivanildo Gomes dos Santos e Mauricéia Ananias

Filosofia Panecástica de Jacotot nos periódicos brasileiros

oitocentistas (1847-48)

Suzana Lopes de Albuquerque

Magistério e literatura em periódicos alagoanos

da década de 1880: as composições poéticas de Alcina Leite e Maria

Lucia Romariz

Maria das Graças de Loiola Madeira

Thomaz Espindola e a Geografia escolar do Império

brasileiro: uma análise do compêndio Elementos de Geografia

e Cosmografia oferecidos à mocidade alagoana (1885)

Edgleide de Oliveira Clemente da Silva

Revisitando Arthur Ramos: a cultura negra e o debate da educação e seu poder de correção e controle social na década de 1930

Monica Luise Santos 
A infância na Revista de Ensino (1927-31) em Alagoas:

um contraponto com Walter Benjamin ................................................. 115

Regina Brito Mota dos Santos

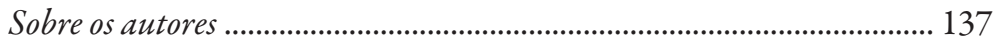




\title{
APRESENTAÇÃo
}

\author{
Carlota Boto
}

Se os campos ou territórios da pesquisa têm uma marca, eu diria que a marca da história da educação brasileira hoje é a de buscar entrelaçar as representações sobre a escola e sobre a infância com os usos e costumes cotidianos das práticas institucionais. Assim, a história das teorias alicerça-se em uma história das práticas. $\mathrm{Na}$ confluência, organizam-se os significados que a área vem conferindo à temática. A história dos discursos educacionais presentes nas teorias, nos jornais, nos periódicos, na literatura, no Parlamento, articula-se com outra história, que diz respeito aos métodos, às cartilhas, aos compêndios didáticos, às salas de aula, aos cadernos de classe... O resultado desse procedimento metodológico, que diversifica suas fontes documentais e as perguntas que são lançadas a elas, corresponde a um inventário de atividades de ensino efetivamente engendradas no dia a dia das instituições escolares.

O livro organizado por Edgleide de Oliveira Clemente da Silva, Ivanildo Gomes dos Santos e Suzana Lopes de Albuquerque, sob o ilustrativo título $A$ história da educação em manuscritos, periódicos e compêndios do século $X I X e X X$, corresponde ao que há de mais fértil na produção da história da educação brasileira. Entremeando um conjunto variado de documentos, os autores palmilham criteriosamente o campo da pesquisa e da escrita da história da educação, concentrando-se, sobretudo, na trajetória do debate pedagógico e das instituições escolares de Alagoas. Cada um dos capítulos tem uma identidade própria, embora eles apresentem entre si uma clara interface, como numa teia que confere a urdidura ao sentido de conjunto. 
Em "A instrução nas Alagoas no período colonial: os manuscritos e os primeiros vestígios de uma educação não dirigida por religiosos", Ivanildo Gomes dos Santos e Mauricéia Ananias debatem o tema da relação do historiador com suas fontes e seus arquivos. Ancorados na referência de Marc Bloch e Certeau, os autores refletem sobre os procedimentos de interrogação das fontes. A partir daí, retomam a formação histórica de Alagoas e o modo como foi instituída a educação religiosa nos primeiros tempos da colônia. Identificando a região como sendo marcada pelo latifúndio, pela escravidão e pelo patriarcalismo, os autores atentam para a maneira pela qual esse território, que apenas em 1817 se emanciparia de Pernambuco e passaria a constituir a capitania de Alagoas, abrigou ainda no século XVI missionários franciscanos e carmelitas que buscaram converter os índios ao catolicismo, dedicando-se, nesse sentido, à educação e à catequese. $\mathrm{O}$ texto, que trabalha com fontes inéditas, volta-se para a indagação sobre a possibilidade de existência de aulas públicas na Comarca no último quartel do século XVIII. Para tanto, vale-se de um requerimento de um professor que pedia à rainha, no ano de 1784, um adiantamento de seus vencimentos. Ele havia sido recentemente nomeado como professor de Gramática Latina da Vila de Alagoas e pedia o referido adiantamento para pagar suas despesas, sobretudo, as de transporte. Os autores consideram que esse seria o primeiro professor público localizado em Alagoas, lembrando que ele teria sido processado pelo Santo Ofício no ano de 1796, sob a acusação de fazer proposições heréticas, agindo de forma pouco condizente com o padrão estabelecido naquele tempo. Trabalhando outros casos como esse, o texto identifica um paradoxo entre a orientação religiosa do mundo luso-brasileiro e o período de renovação, a partir dos ideais do Iluminismo. Os autores levantam um conjunto de professores com trajetórias bastante significativas para sua época, dentre os quais o professor de Geometria Joaquim de Amor Divino, o Frei Caneca, que, entretanto, exerceu a cadeira por pouco tempo. 
Suzana Lopes de Albuquerque, em "Filosofia panescática de Jacotot nos periódicos brasileiros oitocentistas (1847-48)", reporta-se ao debate, no Brasil do século XIX, entre os métodos de leitura e os modos de ensino. A autora parte do pressuposto de que havia um contexto de internacionalização das ideias pedagógicas e que isso levou a que um modelo de ensino desenvolvido pelo francês Joseph Jacotot fosse apropriado para o Brasil, a partir da ação de José da Costa e Azevedo, primeiro diretor da Escola Normal de Niterói. O referido capítulo discute como o periódico Sciencia divulgou, entre 1847 e 1848, esse método de Jacotot a partir de seus seguidores brasileiros e do embate que ocorria com a figura pública de António Feliciano de Castilho, um educador português que também tinha interesse em divulgar no Brasil seu método de alfabetização. Nessa revista, havia explicações sobre os princípios do método de Jacotot, sua história e os modelos de sua aplicação. É muito interessante o embate de Costa Azevedo com Castilho. Este último dizia rejeitar o método que ensinava a ler por sílabas, somando-as para a formação das palavras. $\mathrm{O}$ método de Castilho era sintético e tomava como ponto de partida o ensino das letras por seus sons. Mas, no fundo, o que estava em causa era a possibilidade de o Império assumir um dos referidos métodos de ensino. Suzana, nesse capítulo, reconstitui um importante episódio, portanto, seja da história da didática em nosso país, seja, de maneira mais ampla, da história da educação e do debate das ideias pedagógicas.

Maria das Graças de Loiola Madeira escreve o capítulo intitulado "Magistério e literatura em periódicos alagoanos da década de 1880: as composições poéticas das professoras Alcina Leite e Maria Lucia Romariz". Alcina Leite publica em 1889, em Alagoas, a obra de poesia intitulada Campesinas. Em 1888, Maria Lucia Romariz cria um almanaque voltado para a publicação de produções literárias de mulheres. As duas foram, assim, protagonistas das primeiras publicações femininas na província alagoana. Eram 
duas jovens professoras que enfrentaram a produção predominantemente masculina do mercado editorial. Ambas, então, naqueles anos, iniciavam sua carreira docente e, paralelamente, sua atividade literária. Maria das Graças propõe-se a reconstituir essa história como uma forma de meditação sobre os vínculos entre magistério e literatura no Brasil imperial. Nesse sentido, a autora recompõe delicadamente a literatura poética de Alcina Leite, trazendo à tona sua obra, para conhecimento do leitor. Ao fazer isso, aparece no texto algum eco da "história das mentalidades", já que recompor a produção da poetisa significava confrontar as maneiras pelas quais ela representava a si mesma e sua própria época em seus escritos. Maria Lucia Romariz, que havia sido fundadora do colégio Atheneu Alagoano, fundou também a Revista Alagoana e o Almanach para senhoras alagoanas. Por essa dupla iniciativa, visava a divulgar a literatura feminina brasileira. Com o colégio Atheneu, por sua vez, Maria Lucia pretendia oferecer às moças alagoanas a possibilidade de frequentar um curso secundário, com a finalidade de que elas se preparassem para, em seguida, adentrarem o curso superior. Maria das Graças considera que a trajetória de ambas as intelectuais expressava um protagonismo no magistério primário, que se dava, sobretudo, por uma ativa e militante escrita literária desenvolvida pelas duas.

Em "Thomaz Espindola e a Geografia escolar do Império brasileiro: uma análise do compêndio Elementos de Geografia e Cosmografia oferecidos à mocidade alagoana (1885)", Edgleide de Oliveira Clemente da Silva trabalha a obra do médico alagoano Thomaz Espindola. Esse intelectual era professor de Geografia, Cronologia e História no Liceu de Alagoas, sendo também professor de Higiene no Liceu de Artes e Ofícios. Além de professor, Espindola foi diretor geral dos estudos entre 1866 e 1868. Foi deputado em várias legislaturas e atuou inclusive como presidente interino da província de Alagoas. Ele defendeu que a cadeira de Geografia e a de História, bem como a de Língua Inglesa, permanecessem como 
matérias obrigatórias nos currículos do Liceu. Elaborou seu compêndio de Geografia como estratégia para divulgar uma dada concepção desse conhecimento geográfico, que colocou como saber voltado para a mensuração e para a modelação das demais ciências. Nesse sentido, Espindola conferiu prioridade ao ensino de uma Geografia Geral, que pudesse abarcar os distintos conhecimentos geográficos que formam os diferentes continentes do globo. Essa concepção é correlata a uma determinada visão de civilização que tem na lógica evolutiva seu significado. Haveria estágios de evolução entre povos que, por comparação, seriam selvagens, bárbaros ou civilizados. O saber da Geografia teria, portanto, o papel de indicar uma determinada concepção de civilização, que tem a marca europeia como sua principal referência.

"Revisitando Arthur Ramos: a cultura negra e o debate da educação e seu poder de correção e controle social na década de 1930" é o título do capítulo de Monica Luise Santos. A autora aborda a trajetória do intelectual Arthur Ramos para mostrar o quanto ele se contrapôs à perspectiva do evolucionismo social, tão cara a outros teóricos de sua época. Em $A$ criança problema, Arthur Ramos desfaz a visão racista de toda uma geração de intelectuais, que pensavam a nação em termos de raças e, por aí, postulavam a inferioridade da população brasileira. Arthur Ramos contrapôs-se à matriz da raça como motivo da explicação do país, mas recaiu em outra fonte de estigma, expressa na ideia de que existiriam culturas adiantadas e culturas atrasadas. Nesse sentido, o problema que deixara de ser médico-biológico, tornava-se cultural. A sociedade brasileira permanecia classificada como atrasada pelo fato de ser marcada por uma mentalidade pré-lógica. A educação era tida aqui como dispositivo para engendrar comportamentos considerados adequados e bem-quistos do ponto de vista social. A partir de 1933, Arthur Ramos - a convite de Anísio Teixeira e, portanto, no âmbito do movimento da Escola Nova brasileira - dirigiria o Serviço de Ortofrenia e Higiene Mental do Instituto de Pesqui- 
sas Educacionais do Rio de Janeiro. Foi na direção desse Instituto que ele realizou as pesquisas que resultaram em algumas de suas principais publicações, entre as quais, A criança problema, de 1939. Dessa maneira, Monica Luise Santos conclui, demonstrando que Arthur Ramos recusou a tese de inferioridade biológica da população negra, mas não rejeitou a tese segundo a qual haveria indícios de inferioridade cultural da parcela iletrada da população. $\mathrm{O}$ povo continuava, assim, subsumido por seu lugar social em um estado varguista que se pretendia moderno e civilizado.

Regina Brito Mota dos Santos, no capítulo intitulado "A infância na Revista de Ensino (1927-31) em Alagoas: um contraponto com Walter Benjamin”, aborda um periódico - Revista de Ensino - dirigido aos professores e que publicava planos de aula e ensaios dos docentes da Escola Normal de Maceió, do Liceu Alagoano e dos Grupos Escolares. A referida revista, a par dessa atividade, tinha o intuito de espraiar o pensamento pedagógico produzido na Europa e na América do Norte, como instrumentos voltados para a possibilidade de solucionar os impasses do ensino no Brasil. Havia - como diz Regina - uma "pluralidade de vozes” na configuração da Revista: por um lado, a predominância do discurso da Escola Nova e, em especial, de John Dewey; e por outro, a predominância de um discurso católico, que pretendia, pela educação, preservar valores morais religiosos. Daí a autora relata que Saviani identifica na Revista de Ensino uma espécie de "Escola Nova católica”. Buscava-se a modernização do Brasil e, com isso, tematizavam-se o corpo e a mente, bem como a higiene da criança. Rejeitava-se a memorização de conteúdos no ensino ministrado. Defendia-se a observação e a experimentação como instrumentos para a preparação para o mundo do trabalho. A escola ativa considerava a proeminência da criança no ato educativo. Nesse sentido, valorizava as condições de sua espontaneidade. A autora apresenta o relato de alguns artigos, como, por exemplo, o texto "Disciplina da liberdade", publicado na Revista do Ensino em 1928. Tomando 
a perspectiva de Montessori como ideal regulador, a liberdade da criança era defendida como uma tática para cultivar nesta um autocontrole, passível de pautar-se em hábitos de asseio, de ordem e de disciplina. Esse discurso se coadunava com a proposta da Igreja Católica, que vê na criança a imagem de uma criatura edulcorada, produtiva e iluminada. A criança que conferirá, portanto, centralidade à harmonia familiar. Essa infância idílica não encontrava correspondência na situação de pobreza extrema em que vivia a maioria das crianças no Brasil. A realidade histórica na qual se encontrava a infância real não era, portanto, contemplada nos discursos que diziam a infância idealizada.

Enfim, amparados por significativos conjuntos documentais que constituem as fontes das análises aqui empreendidas, os pesquisadores envolvidos neste livro reconstituem trajetórias de infância e percursos de escola bastante interessantes para se pensar não apenas a história da educação de Alagoas, mas também, sobretudo, a história da educação brasileira. Além disso, trata-se do conjunto de temas e de problemas originais e criativos, que dão a ver aspectos importantes da história da cultura no país. 


\section{PREFÁCIO}

\section{(Des)alinhando expectativas em torno de manuscritos e impressos alagoanos}

José G. Gondra

Lançado em 2015, o filme Spotlight dá visibilidade às experiências ocorridas na cidade de Boston, em 2001. Trata-se de um tipo de drama biográfico dirigido por Tom McCarthy, no qual um grupo de jornalistas investiga casos de pedofilia praticados por padres católicos, acobertados pela cúpula da Igreja. Ao reunir e tratar de um importante conjunto documental, os jornalistas denunciam as violências cometidas e o envolvimento de líderes religiosos nas experiências descritas. Ao posicionar o espectador dentro da redação e no processo de investigação que realizam, o diretor assinala um modo de se praticar o jornalismo investigativo, chamando atenção para o que mobiliza aqueles profissionais na denúncia da hipocrisia, da burocracia e do abuso sobre os mais desfavorecidos. Indicado para seis categorias do Oscars na premiação de 2016, ganhou os prêmios de melhor filme e melhor roteiro original.

Em certo sentido, o presente livro, organizado por Edgleide de Oliveira Clemente da Silva, Ivanildo Gomes dos Santos e Suzana Lopes de Albuquerque, funciona como uma espécie de holofote sobre acontecimentos pouco conhecidos, sombreados por uma historiografia panorâmica, produzida, sobretudo, no sudeste do Brasil, que tem o mérito de transformar em nacional o que se processa nos planos estadual e regional. Desse modo, ao girarem a lente e reunirem seis 
estudos, os organizadores combinam um material que torna mais complexas as intrigas ou narrativas da história da educação brasileira.

$\mathrm{O}$ primeiro estudo oferece elementos importantes para se pensar a respeito da educação ofertada por não religiosos na região de Alagoas. A localização e o tratamento de fontes primárias pelos autores, até então desconhecidas no âmbito da historiografia da educação alagoana, dão a ver uma série de acontecimentos que permitem compreender as estratégias e possibilidades voltadas para a oferta de instrução nas Alagoas. Nessa espécie de genealogia das formas educativas, os autores reconhecem a existência de relações de poder que marcam a atuação de professores e da comunidade interessada na difusão das letras por parte de agentes não vinculados à hierarquia da Igreja Católica, a partir da segunda metade do século XVIII, na Vila de Alagoas.

$$
\text { viscipscio ixmitiketuat. }
$$

A Amrica du Norte apresenta neste momento uni facto, que se reproduz em todu o mundo, mas que passa desapercelido, isto $\dot{b}$ homens do poro, olliciaes de oflicio applicando ás letras, sciencias e arı es, âs disposiçóes que receberio da nalureza, fazerem-se celebres por seus conhecimentos, e preslarem serviços a humanidade apczar do seu cstado de officiacs de officio.

Elitu Burritt, nascido em 1811 no estado de Councticut, filto de um sapateiro, andou n'uma escola por tres mezes; porém as circumstaneias de seu pai o sapateiro obrigárăo Elihu Burritt a trabalhar de um officio, e como a sua natureza physica era muito robusta, entrou na oflicina de um ferreiro, e consagrava ao estudo os puucos instantes que lhe sobrávão. Sosinho, sem mestre algum, pela unica força da sua energica vontade, applicando assitn por intuiçăo os principios do Jacotismo, o ferreiro Burritt conseguiu apprender as mathematicas, o latim, o grego, o francez, o italiano, o allemão, o hespanhol: Já, sem o querer, o ferreiro tinha ganhado fama: offerecerão-lhe a direç̧ão de um col. legio; mas no fim de um anno alterou-se a sua saudo por causa da assiduidade que exigião uma vida tão sedentaria e os esforços de. estudo que tinha feito; voltou para a officina e a bigorna, e em breve ficou restabelecido. Pouco depois una casa de commercio the offerecen um emprego vantajoso; durante as viagens que fazia para os interesses da casa, apprendeu a lingua hebraica e escreveu o seu primeiro opusculo, o Tumulo do meu Irmão. 
O segundo estudo incide em uma temática muito cara para se pensar a problemática da instrução e das propriedades gerais do aparato escolar. Trata-se das mediações e disputas em torno do melhor e mais eficaz método de ensinar e de toda a utensilagem, indústria e comércio associados ao mesmo. Nesse caso, a autora elegeu e se debruçou sobre uma experiência extremamente instigante, pois coloca em xeque os mecanismos da colonização portuguesa em suas permanências com a complexa circulação de pessoas, matérias e modelos pedagógicos ao longo do século XIX. Com isso, ao eleger as proposições de Jacotot e suas apropriações no Brasil, a pesquisa ajuda a interrogar os interesses de uma pedagogia nos marcos da experiência portuguesa. Jacotot viveu no século XVIII, na França, e se tornou conhecido por ter elaborado uma proposta de método pautada na emancipação intelectual ${ }^{1}$. Jacotot formulou sua proposta a partir de uma experiência inusitada, quando se viu constrangido a ensinar francês para holandeses, em uma situação de dupla ignorância. Diante desse desafio, a partir de uma edição bilíngue do livro Telêmaco, percebeu que qualquer pessoa pode aprender sozinho e que o professor pode ensinar mesmo que ignore uma determinada matéria. $\mathrm{O}$ método apresenta quatro pilares: o primeiro afirma que todos os homens possuem igual inteligência; o segundo, que cada homem recebeu de Deus a faculdade de aprender sozinho; o terceiro, que podemos ensinar o que não sabemos; o último, que tudo está em tudo. Na avaliação de Jacotot, o conhecimento é um direito e todos podem adquiri-lo, sendo a disposição para aprender a exigência fundamental. Denominado método de educação universal, "esse método da igualdade era, antes de mais nada, um método da vontade. Podia-se aprender sozinho, e sem mestre explicador, quando se queria, pela tensão

1 Disponível em: http://memoria.bn.br/DocReader/docreader.aspx?bi$\mathrm{b}=730076$ \&pesq\%22pesq. Acesso em: 6 nov. 2017. 
do próprio desejo ou pelas contingências da situação" (Rancière, 2002). As proposições e seus princípios parecem ter sido objeto de uma difusão com algum grau de alcance na América $^{2}$, como pode ser observado no caso de Elihu Burrit, noticiado pelo Jornal Sciencia, de 1847 , na matéria seguinte a que noticia a criação do Instituto Panecástico do Brasil.

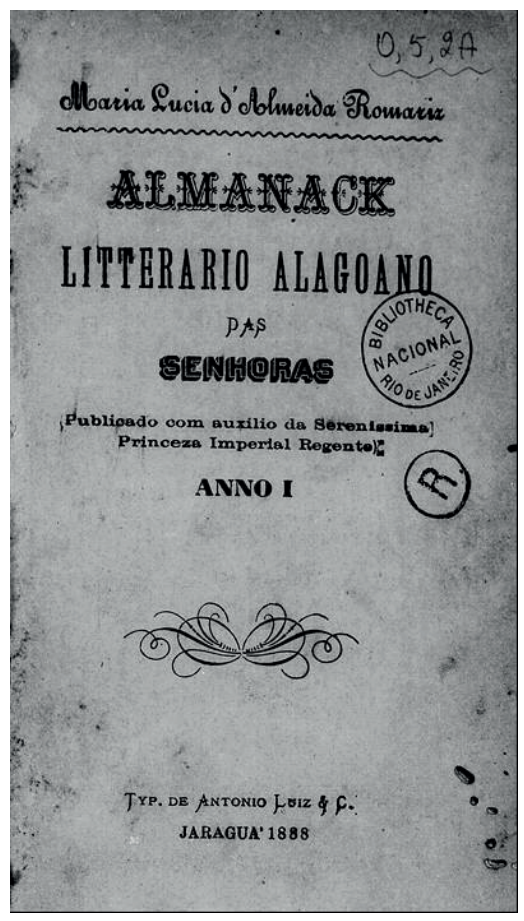

O terceiro estudo entrecruza elementos da história de professoras com a inserção pública do feminino em outros ambientes da vida pública. No caso, o jornalismo e a literatura. A autora explora

2 A respeito da circulação das proposições de Jacotot em outros países da América, cf. Kohan, 2013. 
os primeiros indícios da escrita literária de professores. Ao selecionar duas experiências de professoras-autoras, a pesquisa lança luzes e interrogações a respeito das trajetórias de Alcina Carolina Leite (1854-1939) e Maria Lucia d'Almeida Romariz (1863-1917) na escola provincial e na vida pública alagoana. Para tanto, a pesquisa focaliza o projeto de publicação do Almanack Litterario Alagoano das Senhoras ${ }^{3}$ (1888), publicado em Maceió, com auxílio da Sereníssima Princeza Imperial Regente, com a colaboração de nomes da literatura brasileira feminina, entre as quais, a baiana Ana Autran, a pernambucana Francisca Izidora, as cearenses Francisca Clotilde e Alba Valdez, as gaúchas Cândida Fortese Senhorinha Chaves, a paraibana Anna Ribeiro e as sergipanas Maria Cândida Ribeiro e Maria Minervina de Menezes. De acordo com o estudo, apesar da condição feminina desfavorável em ambas as posições, as respectivas trajetórias foram de algum modo protegidas dos estigmas da época, considerando a projeção das duas professoras no universo literário nacional e internacional. Os versos contidos, que anunciavam uma vida silenciada e subjugada à figura masculina, não condiziam com o fato de terem se insurgido como figuras singulares em um cenário que inibia o exercício da intelectualidade feminina.

O quarto estudo incide sobre a trajetória de um sujeito poliédrico e um polígrafo, com foco em uma de suas intervenções no campo da educação, isto é, a produção de livros destinada ao universo escolar. Trata-se de um homem que ocupou posições sucessivas e simultâneas no campo médico, pedagógico, da gestão, da política e da literatura: Thomaz do Bomfim Espindola (1832-89). A produção intelectual desse autor recobre campos disciplinares diversos, tendo produzido na área da Medicina e da Educação, a

3 Disponível em: http://memoria.bn.br/DOCREADER/docreader.aspx?$\mathrm{BIB}=707260$. Acesso em: 06 nov. 2017. 
citar: Profilaxia do "colera morbus" epidemico: sintomas, tratamento curativo desta molestia, dieta, convalescencia, consideraçóes gerais e clinicas (Ceará, 1862); Relatório da Instrução Publica e Particular da Província das Alagoas (1866, 1867 e 1868), escrito durante a ocupação do cargo de Diretor Geral de Estudos, em cujo conteúdo faz um levantamento da situação escolar de Alagoas dos anos de 1835 a 1865 . Há também a obra geográfica Geografia alagoana ou descrição fisica, politica, historica da provincia das Alagoas, publicada em duas edições (1860 e 1871). De acordo com a pesquisa realizada, o livro Elementos de Geografia e Cosmografia oferecido à mocidade alagoana (1885) ampara-se em alguns referenciais utilizados nos principais colégios europeus. Desse modo, a terceira edição deste livro é descrita como "a mais correcta e de accordo com os progressos da ciência”. O saber geográfico procurava cumprir a dupla função de mensurar e absolutizar. A mensuração ou demarcação deveria constar nas escolas, a fim de preparar os sujeitos para conhecerem e zelarem pela integridade geográfica do país. A segunda função visava a colocar a ciência geográfica como modeladora das demais, posto que se autorrepresentava como uma "ciência das evidências", equivalente, portanto, à racionalidade que tinha como objeto os elementos físicos e naturais, pautada na observação, na descrição e na experimentação.

O penúltimo estudo incide igualmente sobre outro personagem alagoano poliédrico e polígrafo. Trata-se, nesse caso, de Arthur Ramos (1903-49). Filho de médico e formado em Medicina pela Faculdade da Bahia, em 1926, na curta vida, deixou um legado de mais de seiscentas obras, entre livros e artigos, que até hoje são fontes para a psiquiatria, o negro, o índio e o folclore brasileiro. Esse estudo procura refletir a respeito da compreensão de Arthur Ramos em relação à cultura negra e seu valor na constituição e formação do negro. Para a autora, os estudos de Arthur Ramos sobre as relações da cultura negra com a educação devem levar em consideração os limites e possibilidades de sua época, contribuin- 
do para revogar a tese da inferioridade biológica do negro. No entanto, advoga que Ramos também contribuiu para a permanência da tese da inferioridade cultural das populaçóes que não tinham acesso ao saber letrado. Para ele, os grupos considerados atrasados culturalmente apenas evoluiriam por meio da educação escolar, considerada pelos intelectuais como chave para se alcançar o progresso e a civilização do país. Mas não qualquer educação. Esta deveria estar pautada em postulados e procedimentos médico-higiênicos, como os que teve oportunidade de executar ao ser convidado por Anísio Teixeira para chefiar o Serviço de Ortofrenia e Higiene Mental-SOHM (1934-39). Na direção do SOHM, o médico alagoano analisou mais de 2000 estudantes de escolas públicas do Rio de Janeiro, buscando romper com algumas concepções que rotulavam crianças como "anormais" por apresentarem comportamentos tidos como inadequados, tais como desatenção, rebeldia e mentira, entre outros. Defendia que os comportamentos não estavam associados a uma matriz genética, mas, sobretudo, social. Assim, comprovou no referido serviço que a maior parte dos comportamentos tidos como indesejáveis decorria de situações sociais na casa e na escola. Desse modo, minimizou a questão racial, biológica e genética, acentuando o papel das condições na constituição das condutas e comportamentos dos sujeitos.

O último estudo recobre o tema da infância, tomando como fonte uma revista pedagógica. A autora opera com a Revista de Ensino ${ }^{4}$, veículo oficial da Diretoria Geral da Instrução Pública de Alagoas, criada em 1925, tornando-se, posteriormente, periódico de divulgação da Sociedade Alagoana de Educação, a partir de 1930 .

4 Disponível em: http://memoria.bn.br/DocReader/docreader.aspx?bi$\mathrm{b}=761559$ \&pasta $=$ ano\%20192\&pesq $=$. Acesso em: 15 maio 2018 . 


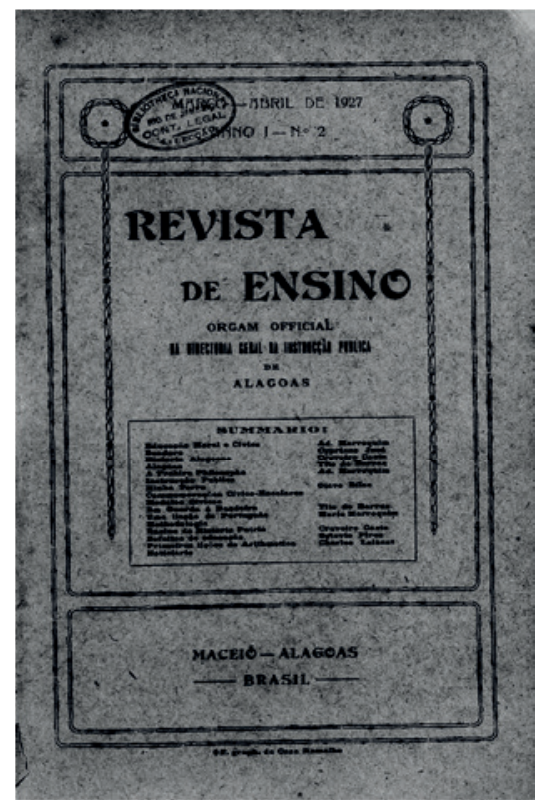

De acordo com a pesquisa, o impresso em questão passou a ser um meio de fornecer informação aos professores e divulgar os novos processos de ensino, já que eram publicados planos de aula, ensaios de professores da Escola Normal de Maceió, do Liceu Alagoano, dos Grupos Escolares da capital e trabalhos de autores do Brasil e do exterior, focalizando temas relacionados à chamada Escola Nova. Para a autora, uma parcela significativa das representações de infância difundidas pela Revista de Ensino alagoana partia de uma visão ativa, progressiva e, ao mesmo tempo, isolada e individual dessa "etapa” da vida. Os adjetivos atribuídos à infância como um tempo de imitação, fantasia e vivacidade representam uma maneira de enxergar a criança como um ser atuante na construção de um novo tempo e modelável aos objetivos culturais impostos, que, no Brasil, de acordo com argumentos da autora, fo- 
ram fundamentados teoricamente por John Dewey nos debates educacionais promovidos a respeito da Escola Nova.

Por fim, os seis estudos reunidos neste livro de forma meticulosa mobilizam problemas e documentação relevantes para o campo da história da educação. Este tipo de investimento contribui para romper com duas inércias que dominaram o campo da história da educação até os anos 1990. A primeira corresponde a um tipo de narrativa centrada em experiências desenvolvidas nos polos centrais do poder, que assumiam caráter generalizante, nacional. A outra se encontra correlacionada com a inércia dos arquivos. Neste livro, os leitores são provocados e instigados a lidar com coleções e gêneros de documentos bastante peculiares, recobrindo manuscritos, jornais científicos e literários, compêndios e revistas especializadas. Provocação que (re)introduz o leitor em problemáticas de vários presentes, como a da profissionalização do ofício docente, aparecimento da escola, representações da infância, (re)invenção de modos de ensinar, disciplinarização de saberes e participação feminina na cena pública. Organizados sob um alinhamento temporal, os capítulos desalinham percepções consagradas na e pela historiografia da educação ao explicitarem a existência de redes complexas de relações de saber, poder e de agenciamentos empenhados em construir uma escola e uma pedagogia científicas nas Alagoas, parte do Brasil a ser lembrada ou iluminada, tarefa bem cumprida por este livro que, ao fim e ao cabo, funciona como um spotlight.

\section{Referências}

KOHAN, Walter. O mestre inventor. Belo Horizonte: Autêntica, 2013.

RANCIÈRE, Jacques. O mestre ignorante: cinco lições sobre a emancipação intelectual. Belo Horizonte: Autêntica, 2002. 


\title{
A INSTRUÇÃO NAS ALAGOAS NO PERÍODO COLONIAL
}

\section{Os manuscritos e os primeiros vestígios de uma educação não dirigida por religiosos}

\author{
Ivanildo Gomes dos Santos \\ Mauricéia Ananias
}

\section{Introdução}

A história, e consequentemente a história da educação, é (re) construída a partir dos vestígios preservados, pois é justamente da relação do historiador com as suas fontes que se constrói o conhecimento histórico. Estas são matérias-primas indispensáveis para a reconstituição do passado e, portanto, para a operação historiográfica. Assim, para o desenvolvimento de suas pesquisas, o historiador recorre aos arquivos onde estão salvaguardados e preservados os testemunhos do passado, afinal “[...] 'ir aos Arquivos' é uma lei tácita da história [...]” (Certeau, 1982, p. 85) porque dele ficamos à mercê para as nossas ponderações. Desse modo, a busca e a localização das fontes nos arquivos, as técnicas de (re)copiar e transcrever ou fotografar os documentos utilizados fazem parte do conjunto de práticas e técnicas do ofício próprio do historiador e do historiador da educação.

A relação entre os historiadores e as fontes, sobretudo documentais, sempre foi um tanto controversa. Atualmente, o conceito 
de fonte histórica mais aceito é aquele desenvolvido e já bastante discutido pela nova historiografia. Este evidencia que qualquer traço ou vestígio deixado pelas sociedades passadas são fontes para o conhecimento histórico. De acordo com Bloch (2001, p. 79), “[...] a diversidade dos testemunhos históricos é quase infinita. Tudo que o homem diz ou escreve, tudo que fabrica, tudo que toca pode e deve informar sobre ele [...]".

Nesse sentido, o trabalho com as fontes documentais, notadamente as manuscritas, requer do pesquisador algumas noções básicas sobre organização de arquivos, leitura paleográfica e crítica das fontes, conhecimentos que nem sempre são oferecidos pelos cursos de História, e que são aprendidas no dia a dia do fazer historiográfico (Bacellar, 2014).

Salientamos que a busca incessante por documentos nos arquivos não constitui por si só uma pesquisa de grande porte, tendo em vista o risco de cair na simples descrição, ainda que esta possa ser rica em anunciar novos objetos, temas e problemas. Sendo assim, após a etapa de localização e seleção das fontes, faz-se necessário desenvolver a análise, depuração e valorização do seu conteúdo, bem como buscar confrontar os diversos dados apresentados (cruzamento de fontes). Além disso, a triagem de fontes, muitas vezes, já foi feita por aqueles que as produziram, pelos que as conservaram ou destruíram, de forma intencional ou não, e mesmo por aquelas que não resistiram ao poder do tempo.

$\mathrm{Na}$ sequência, faz-se necessário (re)interpretá-las. Essa fase certamente não é o momento mais fácil da pesquisa, pois, conforme alerta Cardoso e Vainfas (1997, p. 377), o exercício da interpretação é extremamente difícil, sobretudo “[...] no caso de pesquisas voltadas para a história das ideias, do pensamento político, das mentalidades e da cultura [...]”. Por isso, é imprescindível interrogar as fontes, fazer os documentos nos indicarem os problemas, afinal, “[...] mesmo os aparentemente mais claros 
e complacentes, não falam senão quando sabemos interrogá-los [...]" (Bloch, 2001, p. 79).

Ainda conforme o autor:

A partir do momento em que não nos resignamos mais a registrar [pura e] simplesmente as palavras de nossas testemunhas, a partir do momento em que tencionamos fazê-las falar [mesmo a contragosto], mais do que nunca impõe-se um questionário. Esta é, com efeito, a primeira necessidade de qualquer pesquisa histórica bem conduzida (Bloch, 2001, p. 75).

Tais questões ajudaram a alargar o entendimento sobre os documentos acessados, tornando-os mais generosos com relação às informações necessárias para o estudo, captando seus sentidos e revelações e podendo ser pródigos a depender do capital cultural do pesquisador e de sua capacidade de associações, confrontações e conjecturas. De acordo com Lara (2008, pp. 18-9), os historiadores precisam "inventar as fontes".

Conforme as perguntas que lhes são feitas, os documentos que sobreviveram até hoje podem se mostrar mais ou menos generosos. Claro está que não se pode fazer qualquer pergunta aos textos que encontramos nos arquivos. Quando queremos saber coisas que não estão explicitamente registradas por eles, ou que não estão ligadas às motivações que deram origem aos escritos, temos que recorrer a estratégias para obter informações - inventar modos e meios de retirar dados e obter respostas para nossas perguntas - e, portanto, inventar fontes.

Colocados em tais termos, o presente texto busca evidenciar a educação nas Alagoas no período colonial, dando destaque às pri- 
meiras iniciativas de ensino não dirigido por religiosos nas Alagoas no final do século XVIII e início do século XIX. As principais fontes utilizadas foram os manuscritos produzidos no período e que estão sob guarda do Arquivo Histórico Ultramarino de Lisboa, aos quais tivemos acesso a partir do projeto Resgate de Documentação Histórica Barão do Rio Brancoํ.

\section{A formação histórica das Alagoas e a educação religiosa nos primeiros séculos}

Comumente, as histórias das Alagoas, sobretudo aquelas que se reportam ao seu desenvolvimento histórico, são unânimes em apontar a região como de civilização da monocultura da cana-de-açúcar, marcada pela tríade: latifúndio, escravidão e patriarcalismo. Foi no "derredor" do açúcar que se desenvolveu a vida sociocultural, política, histórica e religiosa de Alagoas. Todas as áreas estavam interrelacionadas numa dinâmica configuracional, influenciando e sendo influenciadas mutuamente umas às outras. Desta feita, o povo das terras ao sul de Pernambuco teve sua identidade, cultura, costumes, hábitos e tradições atravessadas pelo engenho.

Em $O$ bangüê nas Alagoas, Manoel Diégues Junior (2006)² destaca a importância da paisagem natural, sobretudo das la-

1 O projeto Resgate de Documentação Histórica Barão do Rio Branco (Projeto Resgate) foi criado institucionalmente em 1995 por meio de protocolo assinado entre as autoridades portuguesas e brasileiras no âmbito da Comissão Bilateral Luso-Brasileira de Salvaguarda e Divulgação do Patrimônio Documental (COLUSO). Tem como objetivo principal disponibilizar documentos históricos relativos à História do Brasil existentes em arquivos de outros países, sobretudo Portugal e demais países europeus com os quais tivemos uma história colonial imbricada. Para maiores detalhes, acessar: http://www. cmd.unb.br/resgate_index.php.

2 O primeiro exemplar da obra foi lançado em 1949. Aqui, usamos a 3..$^{\mathrm{a}}$ edição, publicada em 2006, pela Editora da Universidade Federal de Alagoas - EDUFAL, tendo em vista o esgotamento da original e das versóes anteriores. 
goas, rios e riachos, para a implantação dos primeiros engenhos banguês e, consequentemente, a formação histórica das Alagoas. Esse "acidente hidrográfico" da região foi o melhor colaborador para o desenvolvimento econômico, especialmente da cultura da cana-de-açúcar. Ela, a água, fecundava o solo, dava força motriz para as moendas, auxiliava no escoamento da produção, matava a sede, bem como era importante no banho de pessoas e animais.

A colonização, levada a cabo pela união Igreja-Estado, das partes sul da capitania de Pernambuco, território que em 1817 iria emancipar-se, passando a ser chamada de Capitania das Alagoas, deu-se a partir de três principais núcleos de povoamento: ao norte, com a Vila de Porto Calvo; ao centro, com a Vila das Alagoas, atual cidade de Marechal Deodoro; e, ao sul, com a Vila do Penedo. Outro núcleo importante irá surgir com a criação da Vila de Atalaia, após a destruição do Quilombo dos Palmares, no final do século XVII.

Caetano (2015) ressalta que durante os primeiros séculos da colonização o "território alagoano"3 foi abandonado pelo governo de Pernambuco. E, mesmo com a criação da comarca das Alagoas, em 1710, fazia-se necessário que a Monarquia Portuguesa pagasse elevadas quantias ou oferecesse cargos futuros para o estabelecimento dos ouvidores, devido aos tênues rendimentos da referida comarca. Ainda segundo o autor, a criação desta deu-se, sobretudo para o "[...] controle do tabaco e o apaziguamento dos rebeldes da guerra dos mascates que pudessem ter atravessado o território [...]" (Caetano, 2015, p. 187).

Como em outras partes do país, o movimento missionário católico foi parte importante e integrou o processo de colonização

3 O termo está entre as aspas, pois na documentação primária não existe essa expressão, haja vista que o território pertencia a Pernambuco. No entanto, utilizamos para delimitar a região que hoje se conhece como estado de Alagoas. 
da região. Aos religiosos, a partir de uma pedagogia catequética, cabia a educação dos indígenas. Nesse sentido, tinham como principal função "amansar" os nativos, convertendo-os à fé católica e abrindo espaço para os conquistadores ávidos por lucros e riquezas. Conforme Queiroz (2015, p. 36), a cristianização indígena baseava-se em três pilares, quais sejam:

[...] doutrinação, moralização e sacramentalização. Primeiramente os indígenas eram obrigados a aprender de cor as palavras da doutrina cristã (credo) e as orações, mesmo sem entenderem muito bem o que diziam; era a doutrinação. Em segundo lugar, aprendiam a não cometer os atos que eram considerados pecados pelos cristãos daquela época, ou seja, deviam andar vestidos, respeitar a organização familiar monogâmica, a propriedade privada e a trabalharem como os colonos - ou para os colonos. Era a moralização. Finalmente, deviam ser preparados para receber os Sacramentos da Igreja, sobretudo o Batismo e o Matrimônio; era a sacramentalização.

Por volta do ano de 1596, um grupo de missionários franciscanos, oriundos da Custódia de Santo Antônio do Brasil, em Pernambuco, liderados pelo frei Antônio do Campo Maior, iniciou uma missão entre os índios potiguares na ribeira do rio Manguaba, região de Porto Calvo, mais especificamente em Porto de Pedras, no litoral norte das Alagoas. Em virtude da crueldade da expedição, a conversão ao catolicismo tornou-se questão de sobrevivência para os indígenas, uma vez que havia a garantia de que os índios batizados não seriam escravizados, haja vista que, introduzidos no catolicismo, seriam irmãos dos brancos portugueses. Ressaltamos que esse processo não se deu sem a resistência dos povos potiguares, que não aceitavam a religião cristã e chegavam a atacar até mesmo os indígenas cristianizados (Queiroz, 2015). 
Queiroz (2015) afirma que outra missão franciscana foi fundada em 1614 na aldeia Santo Amaro, na região do Pilar (ao centro das Alagoas), às margens do rio Paraíba. Contudo, a escassez de fontes a respeito da referida missão não nos possibilita afirmar quanto tempo durou a missão, nem tampouco quais missionários atuaram nela.

Os carmelitas, por sua vez, nas terras do atual município de Matriz do Camaragibe, litoral norte das Alagoas, por volta do ano de 1749, fundaram o Hospício de Nossa Senhora de Guadalupe, o qual contava com três frades e possuía um patrimônio que “[...] incluía seiscentas braças de terra, mais uma fazenda de gado com meia légua de terra em quadrado [...]" (Queiroz, 2015, p. 43).

Esses missionários franciscanos e carmelitas realizaram várias atividades educacionais, sobretudo a catequese e a evangelização dos nativos, com o intuito de disciplinar e moldar o comportamento dos indígenas. No entanto, ainda que as fontes sejam escassas, é também possível que eles tenham atuado no letramento desses povos.

No que diz respeito à escolarização, as primeiras notícias dão conta da instalação de uma escola jesuítica, em meados do século XVII, na fazenda Urubumirim (atual Porto Real do Colégio). Na escola, "[...] havia o ensinamento misturado à catequese, ensino que ia das primeiras letras até a recitação da jaculatória e à redação de bilhetes [...]" (Duarte, 1961, p. 28). Cabe ressaltar que, apesar da tradição do topônimo Colégio, que inclusive dá nome à cidade, na Residência Jesuítica de Urubumirim era ministrado apenas o ensino primário. Entre os padres jesuítas que atuaram nas terras alagoanas no período está o Pe. Manuel Nunes, dedicado à catequese e ao ensino primário, sendo chamado "[...] mestre de meninos ou ludi magister [...]" (Queiroz, 2015, p. 46).

Verçosa (2006) adverte quanto ao desleixo dos inacianos em relação à educação na região. Conforme o autor, a preocupação 
deles era manter uma fazenda de gado no semiárido alagoano. Vale lembrar que se iniciava na região sanfranciscana das Alagoas o movimento curraleiro com grandes latifúndios de exploração econômica da pecuária leiteira e de corte. Por não terem dado tanta atenção ao ensino, a expulsão da Companhia de Jesus por Pombal, em 1759, não teve grande repercussão na região sul de Pernambuco.

Outros focos de irradiação da cultura letrada deram-se quando da fundação dos conventos franciscanos de Santa Maria Madalena, na Vila das Alagoas, e Nossa Senhora dos Anjos, na Vila do Penedo. As notícias de uma educação institucionalizada oferecida pelos frades franciscanos nas Alagoas aparecem ainda no início século XVIII e dão conta das aulas de Gramática Latina.

Conforme Santos (2007), os primeiros mestres de Gramática Latina no convento de Penedo foram frei Nicolau do Paraíso, que lecionou de 1718 a 1726; e frei Manoel de Jesus Maria, mantendo aulas de 1755 a 1758. Já no convento das Alagoas, sede da comarca desde 1711, a autora assegura que não tenha havido prática escolar até pelo menos 1760, ainda que não possam ser ignoradas as experiências letradas vividas no interior daquela instituição religiosa, de onde saiu frei João de Santo Ângelo, que publicou em Lisboa, no ano de 1755, a Oração panegírico-fúnebre na morte do fidelissimo e augustíssimo Rei D. João V (Queiroz, 2015).

Verçosa (2006) supõe que, até o século XVIII, o ensino das primeiras letras nas Alagoas deve ter sido ministrado por preceptores e padres-mestres nas famílias mais abastadas, as quais, posteriormente, enviavam seus filhos para centros maiores, como Recife e Salvador, a fim de receberem os demais graus de instrução.

Ao que ficou evidenciado, até o final do século XVIII, não houve um impulso de grande monta no âmbito educacional nas 
partes sul da capitania de Pernambuco. A cultura intelectual na comarca das Alagoas era produzida a portas fechadas, "[...] nos claustros sombrios [...]” (Costa, 1931, p. 5) dos conventos franciscanos.

Alguma iniciativa de uma educação dirigida por não religiosos foi feita no final do século dezoito, como veremos na próxima seção.

\section{Primeiras notas sobre a educação pública nas Alagoas}

Ao iniciar esta seção, destacamos que as "primeiras notas" se referem a duas questôes: a primeira indica a ideia de início, de uma gênese da educação pública ou não dirigida por religiosos nas Alagoas; a segunda, a do ineditismo de algumas fontes ou que nunca foram analisadas no âmbito da historiografia da educação alagoana. Via de regra, as pesquisas e os trabalhos produzidos sobre a história da educação nas Alagoas partem das afirmações de Costa (1931) e Verçosa (2006) de que, no final do século XVIII e início do século XIX, existia apenas uma cadeira de Gramática Latina, na Vila das Alagoas, provida em 1798 e mantida pelo Seminário de Olinda, além de duas cadeiras de primeiras letras, uma na sede da comarca (1799) e outra em Santa Luzia do Norte $(1800)^{4}$.

Como ficou evidente na seção anterior, até a metade do século XVIII não foram encontradas notícias a respeito de uma educação não dirigida por religiosos em Alagoas. Algum apontamento

4 Não queremos aqui entrar em confronto nem tampouco desmerecer as pesquisas e contribuições desses dois grandes pesquisadores historiadores da educação alagoana. Temos consciência de que Costa (1931) e Verçosa (2006) deram-nos a conhecer a História da Educação Alagoana a partir daquilo que as condições e fontes lhes ofereciam e do que era possível ter acesso à época de suas pesquisas. 
a respeito de uma educação pública nessa comarca somente será encontrado na segunda metade do referido século. Essas parcas notas dão conta do pagamento do Subsídio Literário ${ }^{5}$ feito pelas quatro câmaras municipais das Alagoas (Vila das Alagoas, Vila de Porto Calvo, Vila do Penedo e Vila de Atalaia), no período de 1774 a 1777.

Segundo atestou Silva (2007), os mapas das cifras desse imposto demonstram com detalhes a arrecadação pelas quatro câmaras municipais das Alagoas. Entretanto, as despesas foram designadas de forma genérica, o que não possibilita a afirmação de que foram “[...] ou não gastos com educação e muito menos se havia ou não escolas e professores nas localidades listadas [...]” (p. 94). O mapa de 1777 informa que as quatro câmaras municipais da comarca das Alagoas contabilizaram 1.391 reses e 1.390 canadas (2.780 litros) ${ }^{6}$ de aguardente para fins de pagamento do referido Subsídio e teve uma despesa de 401 réis.

Nesse sentido, ainda que a fonte não deixe evidente que a despesa de 401 réis tenha sido com a instrução, tampouco indique qual ou quais professores receberam essas quantias, o mencionado gasto nos permite supor a possibilidade da existência de aulas públicas na comarca desde os idos de 1774, pelo menos. As dúvidas permanecem! Todavia, é preciso aqui fazer o exercício de compreender o não dito pela fonte, de enxergar aquilo que está oculto, ou, como afirmou Lara (2008), alargar a fonte com a capacidade de conjecturar do historiador.

5 Imposto criado pelo governo português, após a publicação do Alvará de 1772, para o financiamento da Instrução no Reino e no Ultramar. Para o caso da América portuguesa e da África, a cada 460 gramas (1 arretel - antiga medida de massa/peso - ou 1 libra) de carne verde cortada nos açougues, deveria ser pago 1 real; e a cada dois litros de aguardente da terra (1 canada), pagos 10 réis, para fins do Subsídio (Silva, 2007).

6 Reses estão relacionadas às quantidades de cabeças de gado ou outro animal de corte; e canada diz respeito a dois litros de aguardente da terra. 
A respeito da educação secundária, o requerimento de João Mendes Sanches Salgueiro, que, em 19 de outubro de 1784, solicitava à rainha, D. Maria I, o pagamento adiantado do seu ordenado anual de 300 mil réis, por motivo de sua nomeação ao cargo de professor de Gramática Latina da Vila das Alagoas. Segundo ele, serviria para pagar o seu transporte e, para isso, dava fiança, nomeando por fiador Manuel Francisco Torres, natural de Lisboa e assistente em Arroios (Brasil, Cx. 3, D. 231).

Natural da Vila de Amieira, em Portugal, Salgueiro é o primeiro nome de professor público localizado até agora nas Alagoas. Ainda sobre o professor, vale salientar que, após acusação de D. Luiza Botelho, foi processado pelo Santo Ofício, em 31 de agosto de 1796. Sobre ele recaía a acusação de fazer proposições heréticas, pois, na casa da Condessa de São Miguel, D. Anna, onde ele se hospedava, “[...] mostrava desprezo das imagens de Nossa Senhora, dizia que não havia Inferno; fazendo zombaria dos actos da Religião [...]" (ANTT, 1792). Conforme Fonseca (2009, p. 98.)

Vários de seus ex-alunos foram interrogados, dizendo que o professor comia carne em dias proibidos, que condenava as reverências às imagens sagradas, que faltava com o respeito ao Santíssimo Sacramento, e que desaparecera da Vila supostamente por ter cometido um homicídio. O comissário encarregado chegou, afinal, à conclusão de que não procediam as acusações, embora reconhecesse que o professor não levava uma vida exemplar, sobretudo quanto à prática da religião. O maior prejuízo seria o mau exemplo que ele dava aos seus discípulos, quando deveria, por suas atribuições profissionais, estimular a difusão da doutrina no processo de formação do súdito cristão. 
Observa-se que a conduta do professor não condizia com o padrão estabelecido à época, sobretudo no que diz respeito à obediência, à moral e à doutrina católica, por ser considerado pouco respeitoso com as coisas da religião. $\mathrm{O}$ fato de ser professor agravava ainda mais a situação, uma vez que Salgueiro estaria disseminando a inobservância às leis e às práticas da fé e da religião, bem como porque a formação moral dos alunos dependia do bom exemplo que o professor deveria dar-lhes, o que seu comportamento pouco adequado não permitia.

Outro professor que figurou a aula de Gramática Latina da Vila das Alagoas, no final do Setecentos, foi José Fernandes Gama. Este, que posteriormente foi transferido para a cadeira de Olinda e depois para a do bairro Boa Vista, em Recife, envolveu-se juntamente com o professor José Leitão de Almeida em uma grande querela com o Bispo de Olinda e Diretor Geral de Estudos, D. José da Cunha Azeredo Coutinho. Entre outras acusações, os professores denunciavam o desvio do Subsídio Literário por parte do prelado (Brasil, Cx. 213, D. 14.457).

Em resposta às acusações e procurando provas para incriminá-lo, Coutinho descobriu que, quando professor na Vila das Alagoas, Gama deu provas de desprezo para com a religião e imoralidades, "[...] dificultando o acesso de seus alunos aos eventos religiosos que ocorriam na vila durante os horários de suas aulas [...]" (Silva, 2007, pp. 151-2), conforme atestou o vigário geral forâneo das Alagoas, padre Agostinho Rabelo de Almeida, que era Comissário do Santo Ofício em Alagoas. Além desta, pesavam sobre o professor as denúncias de ter traduzido a Arte de amar, de Ovídio, bem como o assédio, sedução, rapto e abandono da jovem $\mathrm{D}$. Benta Maria da Conceição, entre os anos de 1796 e 1797. Segundo Silva (2007, p. 152),

O pai da menina tratou de enclausurá-la no Recolhimento de Nossa Senhora da Conceição de Olinda, para livrá-la do 
assédio do professor. A clausura não pôde contê-lo porque ele arranjou um jeito de continuar a se comunicar, por cartas, com a moça, até conseguir fugir com ela e ir para o Recife. Naqueles tempos que corriam, ele já havia feito filhos com ela, já a tinha prostituído e abandonado e já estava com uma outra.

Contudo, apesar dessas acusações, Gama saiu ileso, continuou a exercer o magistério e passou a receber uma pensão de $200 \mathrm{mil}$ réis anuais, paga com os valores do Subsídio Literário. Posteriormente, viajou para Lisboa, onde atuou como procurador de uma série de “[...] pessoas importantes [...]" da capitania de Pernambuco (Silva, 2007, p. 153).

Insere-se aqui um paradoxo entre os preceitos e a orientação religiosa do mundo luso-brasileiro, fortemente marcado pela influência da Igreja Católica e pela tentativa de uma renovação a partir dos ideais do Iluminismo. Desta feita, no cotidiano, os professores deveriam ser para seus discípulos o exemplo de uma conduta moral, civil e religiosa, antes que mestres de uma determinada cadeira.

Salientamos que o desenvolvimento da educação não dirigida por religiosos no último quartel do século XVIII não foi um fenômeno específico das partes sul, mas algo comum na capitania de Pernambuco. Conforme Pinheiro (2002), a referência de escolarização pública na Paraíba, então pertencente à citada capitania, remonta ao ano de 1783, quando a cadeira de Latim, criada em 1766, foi provida pelo professor João Adolfo.

Pelo ofício da Junta Governativa da Capitania de Pernambuco ao secretário de estado da Marinha e Ultramar, Rodrigo de Sousa Coutinho, de 1799, bem como pelo ofício do bispo de Pernambuco, D. José da Cunha Azeredo Coutinho, à Junta Governativa da Capitania de Pernambuco, de 27 de setembro de 1800, é possível 
identificar que a comarca das Alagoas possuía, no ano de 1795 , quatro aulas de primeiras letras e duas de Gramática Latina.

As aulas primárias estavam localizadas na Vila das Alagoas, regida pelo professor José Vitorino da Rocha; no termo de Santa Luzia da Lagoa do Norte, regida por Bartholomeu Antonio de Sousa; na freguesia de Porto Calvo, do lente Gonçalo Correia da Costa; e na Vila de Penedo, regida por Miguel Barreto de Almeida. As duas aulas de Gramática Latina eram, em Alagoas, cadeira pertencente a José Pereira Rodrigues de Alcântara, e em Penedo, do catedrático padre Gabriel José Pereira de Sampaio. Os professores das primeiras letras percebiam; $80 \$ 000$ réis, os de Santa Luzia e Porto Calvo; $100 \$ 000$ réis, o de Penedo; e 120\$000 réis, o das Alagoas. Já os de Gramática recebiam: $300 \$ 000$ réis, os de Alagoas, além de uma gratificação de 350\$000; $240 \$ 000$ réis, os de Penedo (Brasil, Cx. 207, D. 14.204 e Cx. 219, D. 14.849). Assim, findo o Setecentos, a comarca possuía quatro professores de primeiras letras e dois de Latim.

Salientamos que o padre Gabriel José Pereira de Sampaio, além de professor de Latinidade da Vila de Penedo, desde 1792, foi um dos últimos funcionários inquisitoriais a atuar na comarca das Alagoas. Natural da Bahia, o sacerdote recebeu a comenda de Comissário do Santo Ofício, em 1808, tornando-se apto a proteger a sociedade contra os desvios da fé católica (Debates de História Regional, 1992). Conforme Machado (2016), padre Gabriel era membro dos quadros mais respeitáveis da Irmandade de São Gonçalo Garcia dos Homens Pardos, da Ordem Terceira e da Irmandade do Santíssimo Sacramento. E, mesmo antes de receber sua habilitação como Comissário do Santo Ofício, o padre denunciou, em 1793, Manoel Gomes Ribeiro e José Gomes Ribeiro, recifenses, irmãos, comerciantes e Familiares do Santo Ofício, de viver cada um em concubinato. A denúncia do padre foi sobre "[...] o horrivel exemplo, dé q na Rua mais publica desta $V^{a}$ [Vila], e junto aos Paços da Camara, em 'q pus Classe vivem 
escandalozissimam ${ }^{\text {et }}$ dous mizeraveis homens concubinados publicam ${ }^{\text {e }}$ de sorte, 'q me faz horror prezenciarem os meus alunos" (ANTT, 1793).

Em 1807, o padre Gabriel Sampaio solicitou ainda à realeza portuguesa a mercê do hábito da Ordem de Cristo, honraria nobilitante da ordem religioso-militar portuguesa sob o controle da Coroa desde finais do século XV. Além disso, suplicava o dobro do ordenado de professor régio de Latinidade e a sucessão ao pároco da Vila do Penedo, António José de Matos, tudo em remuneração dos seus serviços e ao donativo que fez à Fazenda Real como juiz da Irmandade de São Gonçalo Garcia (Brasil, Cx. 6, D. 465). Fica subtendido que o suplicante conhecia bem a dinâmica economia de mercês da Coroa Portuguesa, a qual, para recompensar os serviços dos seus súditos, concedia-lhes várias benesses e privilégios, acompanhados de significativos rendimentos monetários ${ }^{7}$.

Entre as aulas de primeiras letras que existiam na comarca, a da Vila de Penedo era regida, há 15 anos, pelo professor Miguel Barreto de Almeida, que, em 30 de setembro de 1806, solicitou ao príncipe regente, D. João, acrescentamento de soldo para vestuário, alimentos, habitação para si e seus alunos, além de dispensa de cinco anos de serviço para ter sua jubilação. Conforme mapa apresentado anexo ao pedido, Almeida afirma ter ensinado 88 alunos, em 1806 (Brasil, Cx. 6, D. 440).

Em 1798, o governador da capitania de Pernambuco, D. Tomas José de Melo, comunicou aos professores de Gramática Latina que, por Alvará datado de 4 de setembro de 1797, expedido pelo secretário de estado da Marinha e Ultramar, D. Rodrigo de Sousa Coutinho, eles podem utilizar em suas aulas os compêndios

7 A respeito dessa temática, cf. Olival, 2001. 
de suas conveniências e que julgam mais úteis e fácies aos programas de seus discípulos (Brasil,Cx. 201, D. 13.754).

Essa determinação de utilização dos compêndios mais simples e mais fáceis está balizada nas ideias das reformas pombalinas, que considerava a pedagogia jesuítica muito fastidiosa, ao que o Alvará classificava como método antigo. Para Pombal, a aprendizagem deveria reduzir-se aos termos simples, claros e de maior facilidade, como já se praticava nas demais nações europeias. Nesse sentido, a reforma fazia o elogio do ensino rápido, ainda que mantivesse as cadeiras ministradas nos colégios jesuítas (Ramos do Ó, 2009). Salientamos ainda que o conceito de curso rápido foi de grande valia para o sucesso dos colégios particulares, haja vista que o ensino liceal ficou associado a algo enfadonho e maçante pela necessidade do aluno concluir todos os anos do curso para, posteriormente, prestar os exames para as faculdades.

Em 1815, a comarca passou a contar com mais duas vilas, Maceió e Porto Pedras. Tomando emprestado o nome e a padroeira do engenho Massayó, Nossa Senhora dos Prazeres, a Vila de Maceió foi desmembrada da das Alagoas a 05 de dezembro, tendo como espaço territorial a faixa que vai desde a Barra das Alagoas até o Rio Santo Antônio Grande e Mundaú. Desde o século XVII, Maceió já se destacava como sendo um polo de escoamento do açúcar produzido nos engenhos locais, madeiras e algodão, pelo porto natural de Jaraguá. Porto de Pedras, por sua vez, foi desmembrada da Vila de Porto Calvo, e abrangia o território que ia do Rio Manguaba até o Rio Santo Antônio Grande. Segundo alvará de criação, ambas as vilas, deveriam erguer o Pelourinho, a Casa de Câmara, a Cadeia e mais "oficinas necessárias".

Por sua elevação à vila, Maceió ganhou uma aula de instrução primária. Desta feita, em 1818, foi nomeado para professor régio de primeiras letras o padre Francisco do Rego Baldaia, com o or- 
denado de $80 \$ 000$ réis pagos por quartéis ${ }^{8}$, sendo depois substituído por Francisco Pereira Guedes (Costa, 2001). Em mapa datado de $1 .^{\circ}$ de abril de 1819, Baldaia afirma ter ensinado 66 alunos, todos do sexo masculino, tendo entre 5 e 13 anos de idade. É possível também verificar que a maioria, cerca de 44, estava em lições de matemática, como "juros, repartir, sómar, multiplicar e taboada", os outros, nas lições de língua portuguesa: "ler, nomes e abc" (Alagoas, cx. 1799). Entre os alunos listados no mapa de Baldaia, encontra-se Francisco Elias Pereira, que foi professor de Geometria em Maceió, de 1844 a 1849, bem como do Lyceu Alagoano, fundado em 1849.

Padre, jornalista e professor régio de primeiras letras, Baldaia, segundo Queiroz (1996), foi ainda político e agitador popular temível, famoso por sua exagerada lusofobia. Na vice-presidência da Sociedade Patriótica de Maceió, o professor ajudou a fundar o periódico Iris Alagoense, em 1831. Primeiro jornal da província, o Íris Alagoense, editado pelo francês Adolfo Emílio de Bois Garin e redigido pelo padre Afonso de Albuquerque e pelo advogado Félix José de Melo Silva, é considerado o ponto inicial do desenvolvimento político e da formação cultural do povo alagoano (Costa, 2001). Dizia o Íris, em seu frontispício: “A opinião pública acometendo os reis sobre os tronos há de contê-los nos limites de uma autoridade legal"'. A partir de 1832, o periódico passou a denominar-se $O$ Federalista Alagoense, sendo que, em 1833, Baldaia assumiu a direção do jornal.

Conforme Vasconcellos (2016), a Vila das Alagoas ganhou uma aula de Geometria, em 1816. Para essa, cadeira foi nomeado professor Joaquim do Amor Divino, o frei Caneca. Aos 37 anos

8 Um quartel indica um período de quatro meses. Assim, os professores recebiam a cada três meses, regularidade comum à época.

9 Não é objeto deste trabalho a discussão sobre o que era opinião pública para o período ou o que seria entendido por tal expressão. 
e já tendo ensinado as cadeiras de "[...] filosofia racional e moral, e ainda de retórica, nos ambientes que frequentava desde o início do século: o convento do Carmo, a biblioteca dos padres oratorianos, ambos no Recife, e ainda o recém-inaugurado seminário de Olinda [...]" (Vasconcellos, 2016, p. 99), Caneca ficou pouco tempo na comarca, seu desejo era assumir posto semelhante em lugar com maior prestígio, porém o espírito político e revolucionário na Insurreição Pernambucana de 1817 impediu este propósito.

Após a insurreição de 1817, a comarca ao sul da capitania de Pernambuco adquiriu autonomia política, passando a denominar-se capitania das Alagoas, com sede na Vila das Alagoas ${ }^{10}$. Com a criação da capitania, foram criadas mais duas cadeiras, Filosofia e Geometria, na capital.

\section{Considerações finais}

Na busca por apreender a história da educação em Alagoas, este texto ofereceu uma narrativa a respeito da educação ofertada por não religiosos na região. A localização e o trato com fontes primárias, até então desconhecidas no âmbito da historiografia da educação alagoana, trouxe à tona informações, fatos e dados que oferecem uma nova interpretação para o que pode ser considerado a gênese de uma educação pública nas Alagoas, ou pelo menos de uma educação não dirigida por religiosos, como preferimos afirmar.

10 Não quero aqui entrar na discussão interminável que existe entre os autores alagoanos a respeito desse fato, se foi uma forma de punição a Pernambuco na tentativa de enfraquecer a capitania, devido à Revolução Pernambucana de 1817, como defende Moreno Brandão (1909), ou se a comarca já possuía as condições necessárias para emancipar-se, como defende Jaime de Altavila (1988), ou mesmo os dois motivos, como defende Verçosa (2006). 
Essas informações dão conta de que, desde pelo menos 1777 , já havia gastos com educação nas Alagoas, fato que possibilita a afirmação da existência de uma educação pública desde aqueles idos. Outro dado importante diz respeito ao nome e à atuação do professor de Gramática Latina, João Mendes Sanches Salgueiro, primeiro nome de professor público das Alagoas localizado até então.

Por fim, salientamos que as contribuições iniciais que o texto traz para a historiografia da educação alagoana não se esgotam aqui. Não há de nossa parte qualquer pretensão de consumir o enorme leque de interpretações e possibilidades que as fontes documentais podem trazer em futuras pesquisas. Neste texto, entre outras coisas, buscamos apontar caminhos e despertar o interesse daqueles que pretendem enveredar pelos difíceis rumos da investigação histórica em educação.

\section{Referências}

ALAGOAS. Arquivo Público de Alagoas. "Mapa dos alunos que frequentavam as aulas régias das primeiras letras com o professor Padre Francisco do Rego Baldaia da Vila Maceió, 1819”. Cx. 1799.

ALTAVILA, Jaime. História da civilização das Alagoas. Maceió: EDUFAL, 1988.

ANTT/Tribunal do Santo Oficio/Inquisição de Lisboa. Processo de João Mendes Sanches Salgueiro, 1792.

. Cx. 1.643, documentação dispersa 1620-04-22/1820-0912. Processo 17.462. Denúncia contra José Gomes Ribeiro e contra Manuel Gomes Ribeiro, 1793.

AZEVEDO, Fernando de. A transmissão da cultura. São Paulo: Melhoramentos, 1976. 
BACELLAR, Carlos. "Fontes documentais: uso e mau uso dos arquivos”. In PINSKI, Carla Bassanezi. Fontes históricas. São Paulo: Contexto, 2014.

BLOCH, Marc. Apologia da história - ou o ofício do historiador. Rio de Janeiro: Jorge Zarar, 2001.

BRANDÃO, Moreno. História de Alagoas. Penedo: Artes Graphicas Typ. e Pautação, 1909.

BRASIL. MINC. Alagoas. Documentação do Projeto Resgate de Documentação Histórica Barão do Rio Branco. Arquivo Histórico Ultramarino - Cx. 6, D. 465.

. MINC. Pernambuco. Documentação do Projeto Resgate de Documentação Histórica Barão do Rio Branco. Arquivo Histórico Ultramarino - Cx. 3, D. 231.

. MINC. Pernambuco. Documentação do Projeto Resgate de Documentação Histórica Barão do Rio Branco. Arquivo Histórico Ultramarino - Cx. 6, D. 440.

. MINC. Pernambuco. Documentação do Projeto Resgate de Documentação Histórica Barão do Rio Branco. Arquivo Histórico Ultramarino - Cx. 201, D. 13754.

. MINC. Pernambuco. Documentação do Projeto Resgate de Documentação Histórica Barão do Rio Branco. Arquivo Histórico Ultramarino - Cx. 207, D. 14154;

. MINC. Pernambuco. Documentação do Projeto Resgate de Documentação Histórica Barão do Rio Branco. Arquivo Histórico Ultramarino - Cx. 213, D.14457.

. MINC. Pernambuco. Documentação do Projeto Resgate de Documentação Histórica Barão do Rio Branco. Arquivo Histórico Ultramarino - Cx. 219, D. 14849. 
CAETANO, Antonio Filipe Pereira. "A comarca das Alagoas: justiça, trajetórias e conflitos (1712-1817)”. In CAETANO, Antonio Filipe Pereira (org.). Das partes sul à comarca das Alagoas, capitania de Pernambuco: ensaios sobre justiça, economia, poder e defesa (século XVII-XVIII). Maceió: Viva Editora, 2015.

CARDOSO, Ciro Flamarion e VAINFAS, Ronaldo. "História e análise de texto". In (org.). Dominios da História: ensaios de teoria e metodologia. Rio de Janeiro: Campus, 1997.

CERTEAU, Michel de. "A operação historiográfica”. A escrita da história. Rio de Janeiro: Forense Universitária, 1982, pp. 65119.

COSTA, Craveiro. Instrução Pública e instituições culturais de Alagoas. Monografia Escrita por solicitação do Ministério da Educação e Saúde Pública. Imprensa Oficial: Maceió, 1931.

. Maceió. Maceió: Edições Catavento, 2001.

Debates de História Regional, Revista do Departamento de História da Universidade Federal de Alagoas, Maceió, 1992.

DIÉGUES JÚNIOR, Manuel. O bangüê nas alagoas: traços da influência do sistema econômico do engenho de açúcar na vida e na cultura regional. 3 ed. Maceió: EDUFAL, 2006.

DUARTE, Abelardo. História do Liceu Alagoano. Maceió: Departamento Estadual de Cultura, 1961.

FONSECA, Thaís Nivia de Lima e. Letras, ofícios e bons costumes: civilidade, ordem e sociabilidade na América portuguesa. Belo Horizonte: Autêntica, 2009.

LARA, Sílvia H. "Os documentos textuais e as fontes do conhecimento histórico". Anos 90, Revista do Programa de Pós-Gra- 
duação da Universidade Federal do Rio Grande do Sul, v.15, n. 28, pp. 17-39, dez. 2008.

MACHADO, Alex Rolim. "Viver a vida e fiscalizar a dos outros: os agentes da Inquisição nas câmaras, confrarias e milícias em Alagoas colonial, 1790-1820”. Questionis Documenta, Revista do Arquivo da Cúria Metropolitana de Maceió, ano I, n. 1, 2016, pp. 21-45.

OLIVAL, Fernanda. As ordens militares e o Estado moderno: honra, mercê e venalidade em Portugal (1641-1789). Lisboa: Estar, 2001.

PINHEIRO, Antonio Carlos Ferreira. Da era das cadeiras avulsas à era dos grupos escolares na Paraíba. Campinas: Autores Associados, 2002.

QUEIROZ, Álvaro. Notas de história da Igreja nas Alagoas. Maceió: EDUFAL, 2015.

RAMOS DO Ó, Jorge. Ensino liceal (1836-1975). Lisboa: Ministério da Educação, 2009.

REVISTA DO INSTITUTO HISTÓRICO E GEOGRÁFICO DE ALAGOAS. "Registro da Provisão e Alvará porque se mandou crear a vila de Massaió”. V. II, n. 15, pp. 150-5, dez. 1882.

SANTOS, Mônica Costa. Missionários de letras e virtudes: a pedagogia moral dos franciscanos em Alagoas nos séculos XVIII e XIX (dissertação). Universidade Federal de Alagoas, 2007.

SILVA, Adriana Maria Paulo da. Processos de construção das práticas de escolarização em Pernambuco, em fins do século XVIII e primeira metade do século XIX. Recife: Editora Universitária da UFPE, 2007.

VASCONCELLOS, Pedro Lima. "Cenas do catolicismo 'crioulo' na alvorada do século XIX”. Questionis Documenta, Revista 
do Arquivo da Cúria Metropolitana de Maceió, ano I, n. 1, pp. 98-113, 2016.

VERÇOSA, Elcio de Gusmão. Cultura e educação nas Alagoas: história, histórias. 4 ed. Maceió: EDUFAL, 2006. 


\title{
FILOSOFIA PANECÁSTICA DE JACOTOT NOS PERIÓDICOS BRASILEIROS OITOCENTISTAS (1847-1848)
}

\author{
Suzana Lopes de Albuquerque
}

\section{Introdução}

A temática em tela é um desdobramento da pesquisa sobre os métodos de ensino adotados nas escolas de primeiras letras de diferentes províncias brasileiras com circulações advindas de um contexto de internacionalização de ideias pedagógicas da modernidade. A necessidade de adotar um método de ensino no Brasil Oitocentista impôs um debate entre os métodos de ensino de leitura e escrita sintético e analítico e entre seus modos individual, mútuo e simultâneo.

Este capítulo busca compreender as matrizes da Filosofia $\mathrm{Pa}$ necástica presentes no Ensino Universal do francês Joseph Jacotot (1770-1840), apropriado em solo brasileiro pelo primeiro diretor da Escola Normal de Niterói, José da Costa e Azevedo, responsável pela elaboração de um método de leitura que circulara no Brasil sob a base desse autor francês.

A tentativa de compreender o Método Universal proposto por Jacotot e de localizar fontes que demonstrem sua circulação no cenário instrucional Oitocentista brasileiro decorre da pesquisa em desenvolvimento sobre a vinda do poeta português Antonio Feliciano Castilho ao Brasil para divulgar seu método de leitura, momen- 
to em que alcançara embates por defensores de Jacotot no país, entre eles, José da Costa e Azevedo e seus seguidores, como Valdetaro.

Castilho registrou, em carta para sua mulher, o desânimo com os frequentadores do seu curso no Brasil, caracterizando-os como nacionalistas que recusaram qualquer experimentação por dizerem estar utilizando um método propriamente brasileiro que, para Castillho, tratava-se de apropriação das bases do método do francês Joseph Jacotot.

Quanto ao curso, creio que não posso dizer outro tanto, foi muito frequentado, mas nada mais. Esta gente é indolentíssima e tem ainda uma qualidade pior, ou que pelo menos foi pior para o nosso caso: leva o seu patriotismo a um ponto de fúria que faz rir. Como o método é português, e eles têm aqui um chamado Costa Azevedo, que fez uma redução e estropiação de Jacotot, impresso há vinte e um anos, mas desconhecido, pode-se dizer que, por toda a gente, se aproveitaram da franqueza com que sempre convido a discutir e objectar, para virem pôr seus reparos, sob formas muito corteses na verdade, mas completamente sofísticas e de péssima fé. Todos os seus artigos se reduzem, em última análise a que melhor ensinar a ler por sílabas, somando-as como elementos a palavra; bestice inclassificável e imperdoável (Castilho, 1975, p. 285).

O autor afirmou em sua carta a existência, desde 1834, de um método de leitura, uma espécie de redução dos sistemas pedagógicos do francês Jacotot, feita pelo brasileiro Costa Azevedo, motivo esse de intrigas e repulsa ao método português.

Neste escrito, serão contemplados os princípios do Método Universal proposto por Jacotot e os indícios de sua circulação no Império Brasileiro, por meio das fontes pertinentes a Instrução e Ciência, a partir do estudo da vida e obra do professor brasileiro 
Costa e Azevedo e de seus seguidores que militaram em defesa de Jacotot, tornando-se oposição a Castilho.

As fontes localizadas, que comprovam a circulação das ideias de Jacotot no território brasileiro, foram as cartas de Castilho e o periódico Sciencia. Tal material está digitalizado e disponibilizado no site da Hemeroteca Digital da Biblioteca Nacional, em suas 25 edições, sendo cinco que circularam no ano de 1847 e as demais, em 1848. Sua impressão foi realizada na Typographia Universal de Laemmert, no Rio de Janeiro, e tinha suas matérias assinadas pelos professores da escola de Homeopatia, como Luiz Antônio de Castro, João Vicente Martins, entre outros.

Ao trabalharmos com fontes impressas, cabe a nós, pesquisadores, adotarmos uma metodologia que possibilite analisar criticamente e de forma dialética as informações dadas, como sugere a definição de Zicman (1985, p. 100), para quem

um método não é um vale-tudo ou prêt-à-porter, e não deve funcionar como uma camisa-de-força para a análise. Nunca é tarde demais para insistir sobre a natureza dialética das relações método-teoria-objeto de estudo: é este vaivém constante que nos afasta dos perigos do empirismo e do formalismo (grifos nossos).

Para localizarmos a introdução da Filosofia Panecástica de Jacotot no solo brasileiro, foi imprescindível o trabalho com a imprensa a partir do acesso ao periódico Sciencia: “[...] a Imprensa é rica em dados e elementos, e para alguns períodos é a única fonte de reconstituição histórica, permitindo um melhor conhecimento das sociedades ao nível de suas condições de vida, manifestações culturais e políticas, etc.” (Zicman, 1985, p. 90).

Em nossa pesquisa, o trabalho com o periódico possibilitou um melhor conhecimento sobre o método de Jacotot, cujos segui- 
dores brasileiros travaram embates com Castilho na exposição de seu método na Corte brasileira, em 1855.

\section{Construção e princípio do método Jacotot}

Jean Joseph Jacotot (1770-1840) nasceu em Dijon, na França, sendo considerado um expressivo questionador dos resultados da Revolução Francesa e das instituições de sua época, ao denunciar a ineficiência de tais movimentos junto aos objetivos de liberdade e emancipação do homem, inclusive no campo intelectual. Esse contexto é caracterizado por Rancière (2015) como a conciliação entre a ordem e o progresso, inclusive nas instituições pedagógicas, nas quais triunfara o "velho", a partir do silenciamento das febres igualitárias e das desordens revolucionárias e de vozes como a de Jacotot.

Exilado de seu país, com o cessar da Revolução de 1830, o mestre Jacotot regressou à França na tentativa de propagar seu método de ensino, buscando a "Emancipação Intelectual" dos envolvidos no campo educativo.

Ao realizar um estudo, Perella (2011) mostrou o quanto os princípios e as experiências de Jacotot foram propagados rapidamente na França, a partir da criação de uma Sociedade Pedagógica Panécastique $($ Pan = todos; Ekastos = cada um), e de dois jornais, Journal de Philosophie Panécastique o Journal de L'Émancipacion Intellectuell.

No Brasil, tivemos a abertura do Instituto Panecástico baseado nas ideias de Jacotot. Na revista Sciencia (1848, v. 2, n. 16), publicada no Brasil, há uma explicação de seu Ensino Universal e da história de sua produção, bem como o resumo dos princípios e da sua aplicação.

Esse método é explicado no periódico brasileiro a partir da experiência de Jacotot de ensinar aos seus alunos uma língua desconhecida por ele e de ser surpreendido positivamente com a superação destes, que, apesar de terem um mestre ignorante no 
conhecimento daquela língua, obteve êxito com o trabalho do aluno emancipado intelectualmente. Assim, surpreendeu-se com a escrita em francês de seus alunos, uma vez que deixara que eles aprendessem por si.

Elle esperava um dilúvio de barbarismos, e até talvez uma absoluta impossibilidade de exprimirem-se. E com effeito, como podiam estes moços, privados de explicações, reduzidos a si mesmos, comprehender e resolver as difficuldades de uma lingua inteiramente nova para elles? Embora; era necessário conhecer até onde elles tinham chegado por este novo caminho que o acaso tinha trilhado, quaes os resultados deste empirismo desesperado. Qual não foi a admiração do Sr. Jacotot ao descobrir que estes alumnos, sem outro guia, sem outros recursos, que a sua reflexão individual, tinham desempenhado a sua árdua tarefa tão bem como o poderiam ter feito muitos francezes! As explicações então tornavam-se desnecessárias? Por ventura bastaria querer para poder? (Sciencia, 1848, v. 2, n. 16, p. 1).

Dessa experiência, publicou princípios como "pode-se ensinar aquilo que desconhece" (em seu caso experimental, a língua flamenga) a partir do princípio de "aprender uma cousa e a ela referir todo o resto".

Proclamou então o Sr. Jacotot esta máxima - quem quer pôde -, como meio de succeder em todo o trabalho intellectual, máxima esta posta em pratica por todos aqueües que querem neste mundo effectuar coisas grandes; máxima que, quando faz as vezes de uma mola escondida, fez crer em prodigios, e que, em todos os casos, inspira aos alumnos uma justa confiança em si, e os anima para perseverar, afim de colherem o fructo de seus trabalhos. Do successo 
que sempre tinha coroado as suas tentativas, concluio o Sr. Jacotot - que Deos creou a alma humana capaz de instruir-se a si mesma, e sem o concurso de mestres e explicadores 'Enunciou ainda o Sr. Jacotot outros princípios: Aprender ou saber alguma coisa, e a ella referir todo o resto. - Tudo se acha em qualquer coisa. -Todas as intelligencias são iguaes. - Póde-se ensinar aquülo que se ignora. - Isto quer dizer simplesmente que quem quizer, seja quem fôr, pôde tendo confiança em si e vontade, verificar se uma outra pessoa sabe o que tem aprendido' (Sciencia, 1848, v. 2, n. 16, p. 2).

Em defesa da emancipação intelectual proposta pela Filosofia Panecástica do Ensino Universal, Jacotot criticou as discussões que se limitavam à forma de ensinar esvaídas do discurso e das condições materiais políticas e que não problematizavam o princípio de desigualdade da condição dos homens, levando-os a um "embrutecimento".

O Velho não embrutece seus alunos ao fazê-los soletrar, mas ao dizer-lhes que não podem soletrar sozinhos; portanto, ele não os emanciparia, ao fazê-los ler palavras inteiras, porque teria todo o cuidado em dizer-lhe que sua jovem inteligência não pode dispensar as explicações que ele retira do seu velho cérebro. Não é, pois, o procedimento, a marcha, a maneira que emancipa ou embrutece, é no princípio (Rancière, 2015, p. 50).

Em um olhar de longa duração, podem-se contrastar discussões advindas das diferentes matrizes teóricas circuladas no Império Brasileiro, como a do princípio educativo encontrado no Ensino Universal, proposto por Jacotot, que parte de uma tomada de posição diferente do mestre, menos preocupado em transmitir conhecimentos e em buscar métodos de ensino, e mais com a 
emancipação intelectual do seu aluno, a partir de uma condição de igualdade de inteligência.

Ele criticava as preocupações com os métodos que alteravam os “[...] meios escolhidos para tornar sábio o ignorante, métodos duros ou suaves, tradicionais ou modernos, passivos ou ativos, mas cujo rendimento se podia comparar sem, entretanto, partir da concepção de igualdade intelectual entre todos os homens [...]" (Rancière, 2015, p. 32). E esse rendimento mensurável passava pela concepção de uma criança passiva, civilizada e, em suas palavras, embrutecida.

A crítica silenciada de Jacotot dirigia-se aos métodos que circulavam e que atendiam à proposta da escola moderna, caracterizada em suas funções disciplinadora, modeladora, normatizadora e "reguladora da cultura letrada" (Boto, 2012, p. 50). Ele problematizou a preocupação corrente em sua época acerca da metodologia mais aprazível para a criança aprender, que buscava ser inovadora com questões como: A criança está compreendendo? Ela não compreende? Encontrarei maneiras novas de explicar-lhe, mais rigorosas em seu princípio, mais atrativas em suas formas" (Rancière, 2015 , p. 24), mas que não questionavam o princípio da desigualdade entre os conhecimentos, conduzindo, assim, ao embrutecimento do homem e a um modelo social desigual na contramão de uma emancipação intelectual.

Em uma busca pelos periódicos nos campos da instrução e da ciência, deparamos com a circulação das ideias pedagógicas do mestre Jacotot no Brasil. Seu Ensino Universal encontrou adeptos em diferentes escolas brasileiras e nos campos da medicina e da homeopatia, com a criação da Associação Panecástica do Brasil.

\section{A Sciencia: periódico no campo da Homeopatia}

A Filosofia Panecástica encontrou seguidores no solo brasileiro que, em 1847, a partir da vinda do francês Dr. Mure (1809-58), 
criaram a Associação Panecástica do Brasil para desenvolver os princípios do Ensino Universal de Jacotot.

Aos três dias do mez de Maio do anno de mil oitocentos e quarenta e sete, em uma sala da casa da rua de $S$. José, numero cincoenta e nove, tendo-se reunido, à convite do Sr. Dr. Mure, varias pessoas, o Dr. Mure propoz a fundação de uma sociedade para o desenvolvimento dos princípios de Jacotot sobre o ensino universal; aceita foi a proposta por unanimidade, e adoptou-se o seguinte: Em nome de Jacotot, inventor da philosophia panecastica, no dia 3 de Maio de 1847 (Sciencia, 1847, v. 1, n. 3).

A proposta da Associação fundada sob a base do pensamento de Jacotot não se limitava ao campo da discussão no Ensino Superior. Abriu-se um fundo para a criação de escolas para aplicação do Ensino Universal de Jacotot.

Sob proposta do Sr. Dr. B. Mure, foi fundado o Instituto Panecastico do Brazil, cujos estatutos são os seguintes: $\mathrm{O}$ Instituto tem por fim propagar os princípios da emancipação intellectual do immortal Jacotot, e substituir á autoridade e ao pedantismo os direitos da razão humana. $\mathrm{O}$ Instituto procurará reunir um fundo para a creação d'um collegio normal que reunirá. Os presepios. As salas de asylo. Escolas primarias. O ensino superior 1847 (Sciencia, 1847 , v. 1, n. 3).

Os sócios reuniam-se em uma assembleia geral, convocada uma vez por ano, no dia do aniversário da morte de Jacotot, e a instituição promovia conferências semanais para esclarecimentos sobre a aplicação do ensino universal. 
O periódico Sciencia (1847, v. 1, n. 5) tratou da insatisfação de no Brasil não existir nenhum presépio nem casa de asylo e do fato de as escolas primárias existentes não associarem o Ensino Universal ao método de ensino mútuo. Em uma de suas matérias no periódico, foi elogiada a introdução do método mútuo aliado ao ensino simultâneo.

Em relação ao Ensino Superior, foi destacada a experimentação do Ensino Universal na medicina homeopática no Brasil, uma vez que a doutrina do princípio da homeopatia, de Samuel Christian Friedrich Hahnemann, foi fundamentada na emancipação intelectual espontânea sob a base de Jacotot. Segundo Galhardo (1928), os alunos do terceiro ano ensinavam aos do segundo, e estes, aos do primeiro. Seria o princípio do ensino mútuo elogiado na matéria sendo efetivado no Ensino Superior.

A partir da teoria de Jacotot, homeopatia e pedagogia encontraram um momento de interlocução que adentrou o campo da medicina e da instrução no Brasil oitocentista. Esse alargamento de fontes no campo da história da educação, para além dos referentes ao campo instrucional, permitiu uma interlocução do campo pedagógico com os intelectuais que transitavam por diferentes áreas da nossa delimitada ciência moderna.

Sob a base do pensamento de Jacotot, médicos e professores no império brasileiro estavam repensando os métodos e modos de ensino na instrução elementar e superior.

\section{Indícios do Ensino Universal de Jacotot na instru- ção da criança}

A inovação do pensamento de Jacotot em solo brasileiro tratada na revista não se limitava ao campo da homeopatia. Essa filosofia essencialista, presente no periódico $A$ Sciencia, encontrou na máxima da panecastiqué de Jacotot, "tudo está em tudo", sua fundamentação teórica e a interlocução com o campo pedagógico. 
A circulação desse método no campo da instrução elementar brasileira foi-nos apresentada a partir dos registros da carta de Castilho sobre os embates que recebera de Costa e Azevedo e seus seguidores ligados à instrução primária, que, sob a base de Jacotot, travaram duras críticas ao método português.

O seguidor de Jacotot no campo da instrução brasileira oitocentista que travou embate com Castilho, levando-o à suspensão de seu curso na Corte, era o sujeito autor coronel José da Costa Azevedo (1791-1860), o primeiro diretor e organizador da Escola Normal do Rio de Janeiro, em Niterói, "um patrício notabilíssimo olvidado pela ingratidão ou ignorância dos nossos contemporâneos" (Nogueira, 1938, p. 28).

Nas falas de Castilho, observa-se que o Brasil já possuía, desde 1834, um método de leitura, uma espécie de redução dos sistemas pedagógicos do francês Jacotot, feito pelo Brasileiro Costa Azevedo, motivo esse de intrigas e repulsa a um novo método.

Dois traquinas literários com muita basófia, num discurso muito sobrecarregado de encômios a mim, como escritor e poeta, e muito revestidos de fórmulas hipócritas, procuraram suscitar (e com efeito suscitaram) uma cizânia de nacionalidade chocha, dizendo que também havia aqui, impresso, há vinte e um anos, um Método de leitura, coisa grande, feito por um grande homem, em quem a maior parte deles mesmos nunca ouvira falar, chamado José da Costa e Azevedo; que decerto não teria tirado dele o meu, mas que me havia com ele encontrado; que por aquele método se aprendia em seis meses, como se podia ver num colégio desta cidade, etc., etc., etc... (Castilho, 1977, p. 286).

A denúncia de Castilho, nas cartas a sua esposa, dos nacionalistas oponentes ao seu método foi confirmada com a denúncia do representante da província do Piauhy no jornal circulado no 
Rio de Janeiro (1855), no ato de sua ida à Corte para estudar o método Castilho. O Sr. José Martins Pereira de Alencastre deixou registrado em jornal local a sua defesa pelo método português e uma crítica ferrenha aos nacionalistas Costa Azevedo e Valdetaro, que, além de não possuírem um método eficaz, atrapalharam o curso e desprezaram um conhecimento tão necessário em terras brasileiras, que Castilho insistira em ensinar:

O Sr. José da Costa leu o que havia sobre o ensino, leu de improviso Jacotot, quiz em parte imita-lo, em parte seguir um caminho diferente, e nisso foi inconsequente, longo, arido e fastidioso, e completa antilhese do Sr. Castilho, e tão fastidioso, e longo que os alunos matriculados em 1834 na escola da sociedade, de que elle e o Sr. Valdetaro fazião parte, ainda em 1837 não estavao totalmente habilitados nas doutrinas de ler, escrever e contar, cousa bastante pasmosa para mim, que ouvi tanto eucarecer o modo de ensinar do Sr. José da Costa e Azevedo (Correio Mercantil, 1 de maio de 1855, n. 119, p. 2).

A vida de Costa e Azevedo, além da elaboração de suas Lições, embates com o português Castilho, atuação profissional junto à Associação de Instrução Elementar do Rio de Janeiro e à Escola Normal do Rio de Janeiro, em Niterói, entre inúmeros elementos, como aproximaçôes com o método Jacotot e afastamento com o próprio método português, estão sendo analisados na tese de doutorado da autora deste capítulo.

Se em Castilho havia uma crítica sobre o método que ensinava a "ler por sílabas, somando-as como elementos a palavra; bestice inclassificável e imperdoável (Castilho, 1977, p. 285)”, observa-se que a preocupação de Jacotot direcionava-se a outros rumos, a uma epistemologia do conhecimento que problematizava o princípio de desigualdade da condição dos homens na aplicação de métodos que levam a um "embrutecimento". 


\section{Considerações finais}

O princípio essencialista que a homeopatia assumiu, ao tratar o paciente a partir da busca da reação do próprio corpo no combate à doença, em detrimento da aplicação de remédios que combateriam diretamente os sintomas, pode ser comparado ao princípio educativo apresentado no Método Universal de Jacotot, no qual se evitava a inculcação de fórmulas em detrimento de uma pedagogia experimentalista.

A aproximação entre ambas as áreas pode ser observada a partir da análise do periódico $A$ Sciencia, meio em que foram apresentadas e defendidas as ideias de emancipação intelectual propostas por Jacotot, apropriadas para a consolidação da homeopatia em território brasileiro. Tratava-se da recusa de D. Mure aos remédios convencionais e aos mestres explicadores.

Esse é o mesmo princípio contido nas máximas de Jacotot, em que um mestre ignorante poderia ensinar o que desconhecia a partir da verdade da emancipação intelectual, e da máxima de que tudo está em tudo.

Nessa concepção, a cura no campo da medicina e o aprendizado no campo instrucional estariam em todas as partes, uma vez que "Deus criou a alma humana capaz de instruir-se a si mesma, sem o concurso de mestres explicadores"(A Sciencia, 1848, v. 2, n. 16, p. 194). Nessa concepção, estão contidas máximas, como enunciou ainda o mestre Jacotot outros princípios: "Aprender ou saber alguma coisa, e a ella referir todo o resto. - Tudo se acha em qualquer coisa. - Todas as intelligencias são iguaes. - Póde-se ensinar aquülo que se ignora" (A Sciencia, 1848, v. 2, n. 16, p. 193).

Dessa forma, para Jacotot, o que emancipa ou embrutece não é o procedimento, a marcha, o método, e sim o princípio. Em defesa do princípio de igualdade, em seu Ensino Universal, esta não toma o objetivo a atingir, mas o ponto de partida, a ser mantida em qualquer circunstância. 


\section{Referências}

A Sciencia, v. 1, n. 3, set. 1847. Disponível em: http://memoria. bn.br/DocReader/docreader.aspx?bib=730076. Acesso em: 10 mar. 2016.

, v. 1, n. 5, nov. 1847. Disponível em: http://memoria.bn.br/ DocReader/docreader.aspx?bib=730076. Acesso em: 10 mar. 2016.

, v. 2 , n. 16 , maio 1848 . Disponível em: http://memoria. bn.br/DocReader/docreader.aspx?bib=730076. Acesso em: 10 mar. 2016.

BOTO, Carlota. A escola primária como rito de passagem: ler, escrever, contar e se comportar. Imprensa da Universidade de Coimbra, 2012.

CASTILHO, Antonio Feliciano. Correspondencia pedagógica. Selecção, introdução e notas de Fernando Castelo-Branco. Instituto Gulbenkian de Ciência, Centro de Investigação Pedagógica, Lisboa, 1975

Correio Mercantil, 1 de maio de 1855, n. 119, p. 2.

GALHARDO, José Emygdio Rodrigues. "História da homeopatia no Brasil”. Livro do $1 .{ }^{\circ}$ Congresso Brasileiro de Homeopatia. Rio de Janeiro: Biblioteca Nacional, 1928.

NOGUEIRA, Lacerda. A mais antiga Escola Normal do Brasil: esbôso de historia administrativa e episódios. Officinas Graphicas do Diario Official do Estado do Rio de Janeiro - Nictheroy, 1938.

PERELLA, Cileda dos Santos Sant'Anna. "Joseph Jacotot: contribuição para a reflexão acerca do conselho de escola" (comunicação oral). ANPAE, 2011. 
RANCIÈRE, Jacques. O mestre ignorante: cinco lições sobre a emancipação intelectual. Trad. Lílian do Valle. 3 ed. 4 reimp. Belo Horizonte: Autêntica Editora, 2015.

ZICMAN, Renée Barata. "História através da imprensa - algumas considerações metodológicas". História e historiografia: contribuições e debates. PUC São Paulo, Programa de Estudos Pós-Graduados em História, Departamento de História. São Paulo: EDUC, 1985. 


\title{
MAGISTÉRIO E LITERATURA EM PERIÓDICOS ALAGOANOS DA DÉCADA DE 1880
}

\author{
As composições poéticas de Alcina Leite \\ e Maria Lucia Romariz
}

Maria das Graças de Loiola Madeira

\section{Introdução}

Em 1889, a professora primária alagoana Alcina Carolina Leite (1854-1939) publicou em Maceió a primeira e única obra de poesia com o título Campesinas, com versos já circulados em jornais de Maceió, Recife e Laranjeiras (SE). No ano anterior, a colega conterrânea, e também professora, Maria Lucia Romariz (186319171), efetivava um projeto ambicioso para uma jovem viúva: pôr em circulação um almanaque destinado a publicar e intercambiar as produções literárias de mulheres brasileiras e portuguesas da década de 1880. Tratava-se do Almanach Litterario Alagoano das Senhoras (1888-89). Editado em Maceió, o periódico recebia a colaboração de nomes com circulação nacional, entre as quais, a baiana Ana Autran, a pernambucana Francisca Izidora, as cearenses Francisca Clotilde e Alba Valdez, a gaúcha Cândida Fortese Se-

1 O ano de 1917 é apenas indicação baseada na consulta aos periódicos. A data exata da morte de Maria Lúcia ainda é desconhecida. 
nhorinha Chaves, a paraibana Anna Ribeiro e as sergipanas Maria Cândida Ribeiro e Maria Minervina de Menezes. As composições poéticas de Alcina Leite e Maria Lúcia tiveram na imprensa periódica seu lugar de circulação, em jornais como Gutenberg, O Orbe, livro e almanaques.

A partir das fontes apresentadas, este texto pretende refletir acerca das relações entre magistério, literatura e imprensa periódica da década de 1880, e a respectiva colaboração de tal produção na conformação de valores morais e sociais que constituíram a sociedade brasileira naquele final de século.

As duas jovens professoras protagonizaram o lugar do feminino numa época de vigilância e dominação da publicação masculina ou dos representantes da intelligentsia brasileira. Desse universo, as mulheres eram geralmente conduzidas com prescrições para qualquer atividade que exercessem em público, em particular, a literatura e o magistério. De algum modo, mulheres como Alcina Leite e Maria Lúcia foram pioneiras em colaborar para um lugar social a partir do qual a figura feminina brasileira se beneficiou ao longo do século XX.

A formação culta e refinada de mulheres como as jovens alagoanas era requerida pela elite nacional para a formação de suas filhas, com o propósito de projetá-las para um lugar socialmente diferenciado dos seus contextos. Essa projeção se daria pela circulação de ideias em impressos e nos demais espaços sociais, inclusive na escola, com a modelagem de mentes e corpos pela ação docente. Nesses termos, Alcina Leite e Maria Lúcia não se associavam ao conceito de intelectuais, com "prática de expor e divulgar ideais e credos políticos" (Boto, 2003, pp. 283-4), mas impulsionaram uma luta quase invisível que representava a saída do confinamento do lar para ganhar um lugar público e de prestígio social (Schueler, 2008).

Inicialmente, este texto discute as relações entre imprensa e literatura no final do Império e seu papel na formação de valores necessários à nação brasileira, que se pretendia republicana. A pro- 
dução literária publicada por professores em periódicos torna-se fonte privilegiada para quem se debruça sobre o tema, tanto pelo uso frequente por parte daqueles que não podiam custear edições de livros quanto pelo período de profissionalização do ofício (Andrade, 2015). Por ser também um lugar de conformação social, a imprensa tornava-se porta-voz do projeto político nacional republicano, considerando a exitosa relação entre palavra e poder exercitada nos jornais de larga circulação, nos periódicos e almanaques especializados (Neves, 2009).

$\mathrm{Na}$ sequência, o texto indaga sobre as relações entre imprensa, magistério e literatura nas composições de Alcina Leite e Maria Lucia, discutindo os modelos de formação para jovens que prosseguiram tanto no universo literário quanto na docência.

\section{A literatura alagoana em periódicos da década de 1880}

A relação entre imprensa e literatura, na segunda metade do século XIX, tornava públicos os valores que constituiriam a nação brasileira, um deles, acerca dos incipientes sinais de uma sociedade democrática que passavam pelo universo das letras. Os intelectuais, em particular os literatos, cumpriram um papel importante naquele momento de fortes convicções político-republicanas, ao tempo em que se profissionalizam em suas especialidades: poemas, contos e romances (Andrade, 2015). Machado de Assis se colocaria a respeito, ao comparar o jornal a um lugar de debate, onde se veiculava diariamente a palavra impressa acalorada (Assis, 1859 apud Andrade, 2015).

Deve-se considerar, entretanto, que o público para o qual se destinavam os jornais era apenas uma pequena parcela da população. E ter lugar na imprensa significava também fazer parte de uma pequena elite intelectual, econômica e política, que facilitava as aproximações com quem detinha o poder, inclusive, de fazer cir- 
cular os periódicos nas capitais provinciais. A circulação da escrita literária tinha também o propósito de render homenagens àqueles da simpatia dos proprietários dos jornais. Isso, portanto, colocava as letras sob a tutela da troca de favores, desde as relações familiares e políticas até as de ordem econômica. Uma vez atendidas as regras tácitas estabelecidas para o ingresso, logo os jornalistas e literatos galgariam ascensão na própria imprensa, no parlamento, nos cargos públicos ou em qualquer outra função. Não por acaso, Andrade (2015) ressalta que a literatura veiculada nos jornais tornava-se um instrumento de formação moral, a exemplo dos folhetins publicados nos rodapés dos jornais, além das seções de poemas, crônicas e contos, que depois se converteriam em outros veículos impressos: revistas especializadas, livros e almanaques. $\mathrm{O}$ espaço reservado à literatura, nesse veículo de informação, seria uma sinalização da imprensa como lugar de exercício de liberdade: “[...] a imprensa periódica pretendia também marcar e ordenar uma cena pública que passava por transformações no âmbito das relações de poder e de suas dimensões culturais e que dizia respeito a amplos setores da hierarquia social em suas relações políticas e sociais" (Neves, 2009, p. 163).

Foi nesse universo intelectual que Alcina Leite e Maria Lucia exerceram os ofícios de literata e professora. Ambas tinham vínculos parentais com pessoas já inseridas no universo da palavra impressa oitocentista. O bacharel e professor primário Antonio Leite Pindahiba, irmão de Alcina Leite, mantinha frequente publicação de composições literárias em jornais de Maceió: O Liberal, Diário da Manhã e Gutenberg. Quando publicou, em 1880, o livro Iris da escola - um pequeno manual de metodologia de alfabetização infantil -, ele recebeu da imprensa notas de incentivo sobre a qua- 
lidade do texto, além de anúncios de venda no jornal $O$ Liberal . É provável que os vínculos do irmão com a imprensa tenham de algum modo facilitado o convite pelo jornal Gutenberg (1881) para que Alcina Leite se tornasse colaboradora da seção "Litteratura", sobre a qual abordaremos à frente.

Quanto à Maria Lúcia, seu esposo Antonio de Almeida Romariz era poeta e professor de francês e latim em Maceió, tendo sido suas composições poéticas publicadas no Gutenberg. Antes de falecer, em 1883, ele reuniu o conjunto de seus escritos literários, circulados na imprensa, e editou a obra Auras matutinas. Em que pese a morte prematura, aos trintas anos, o nome de Antonio Romariz serviu de apoio a Maria Lúcia quando ela fundou, em 1883, o Atheneu Alagoano, um colégio feminino para jovens maceioenses. Particularmente, os redatores do Gutenberg e de OOrbe se diziam sensibilizados com a situação financeira da jovem viúva e, com esses argumentos, passaram a apoiar o seu projeto pedagógico. Em 1888, com o nome já conhecido na imprensa, a proprietária do Atheneu Alagoano pôs em circulação o Almanack Litterario Alagoano das Senhoras ${ }^{3}$. Em decorrência dessas inserções, Alcina Leite e Maria Lucia tiveram seas poemas publicados no Almanaque luso-brasileiro, editado em Lisboa. O conto "Primeira nuvem", de Maria Lucia, foi dedicado ao "festejado poeta pernambucano J.

${ }^{2}$ Em 16 de julho de 1880, o jornal O Liberal divulgava: "Iris da Escola: novo methodo para aprender a ler a letra redonda e a manuscripta em 30 lições, pelo professor Antonio Francisco Leite Pindahiba. Obra organizada sob os novos preceitos do ensino primário ultimamente adoptados a compreensão das crianças" (ano XIII, n. 159, p. 4)

${ }^{3}$ Maria Lucia havia concluído o Liceu Provincial, um feito para poucas mulheres do Brasil Império, considerando que a escola primária e o curso normal eram os únicos caminhos comumente destinados àquelas interessadas em galgar espaços no universo das letras. Anna Sampaio, irmã de Lucia, foi a primeira mulher alagoana a finalizar um curso de Direito (1893). 
Duarte Filho" e publicado na edição de 1887 (p. 132). No mesmo periódico, Alcina Leite publicaria "Sensictiva" .

Como se pode observar, o ingresso das duas professoras e literatas na imprensa local teve a decisiva influência das relações familiares no acolhimento de suas produções literárias. Não chega a ser novidade tal discussão, uma vez que a imprensa era um espaço social tanto quanto outro no Brasil Império, onde prevaleciam às trocas, as relações parentais e a convivência com grupos de prestígio em suas respectivas províncias, para assim também galgarem postos socialmente prestigiados.

\section{A docência e a poesia de Alcina Leite}

Nascida em Atalaia, no ano de 1854, Alcina Carolina Leite Pindahíba formou-se pela Escola Normal de Alagoas, em data ignorada. Em 23 de outubro de $1873^{5}$, aos 19 anos, ela tornou-se professora pública provincial, de uma cadeira do sexo feminino em Coqueiro Seco. Em 1892, Alcina foi nomeada professora do sexo masculino ${ }^{6}$ de $2 .^{\circ}$ grau da Escola Modelo de Maceió, experiência da qual ela se recordou um ano antes de falecer, em correspondência de 09 de novembro de 19387.

No ano da proclamação da República brasileira, a professora reuniu o conjunto de suas poemas e publicou Campesinas, impres-

4 A data exata do periódico não foi localizada. O apoio dessa informação encontra-se em nota do jornal maceioense Gutenberg, de 20 de fevereiro de 1881.

5 Conforme relatório do Governo da Província das Alagoas para o ano de 1882, a turma assumida teve matrícula de 33, com frequência de 20 alunas.

6 Cf. Jornal Cruzeiro do Norte, Maceió, 23 de dezembro 1892. No Regulamento da Escola, aprovado desde 04 de outubro de 1894, consta que ela "obedecia a um regime especial por integrar a Escola Normal responsável pelo ensino pratico. Dividia-se em très graus e era dirigida por seis professores, dividida igualmente pelo sexo" (Relatório dos Presidentes da Provincia das Alagoas, 15 de abril de 1901, p. 09).

7 Carta localizada no acervo do Instituto Histórico e Geográfico de Alagoas. 
so em Maceió, na Tipografia de Amintas Mendonça, com 126 páginas. O título alude à vida rural em Coqueiro Seco, cidade na qual permaneceu até seus últimos dias. Os versos já haviam sido publicados entre 1877 e 1889, em periódicos locais, entre os quais, Gutenberg, A Escola, Almanack Litterario Alagoano das Senhoras, fundado por Maria Lúcia, além de publicações na imprensa fora de Alagoas, Recife e Laranjeiras (SE). Em Novo Almanach de Lembranças Luso-Brazileiro, Alcina Leite publicaria versos sob o pseudônimo de "Sensictiva". O nome da professora e escritora surgia também associado à fundação do Almanack Literário Alagoano para 1900, quando o cronista Luis Lavenère o levou a público, em 1904. Antes da edição de Campesinas, Alcina Leite colaborou de forma vigorosa no jornal Gutenberg, inaugurando a seção "Litteratura”, em 20 de fevereiro de 1881. Ao apresentá-la, o redator do periódico referiu-se a ela como escritora e professora pública de Coqueiro Seco:

Stabat Mater ${ }^{8}$, sob este título abrimos hoje espaço em nosso jornal a uma sublime poesia.

Alcina Leite, meretissima professora publica de Coqueiro Seco.

Tal modesta quão talentosa, a nossa jovem patrícia não vem estrear nas humildes columnas do Gutemberg; em outras jornaes desta capital, e nas paginas do Almanak Luzo-Brasileiro, sob o pseudônimo - Sensictiva - já tem a exma. d. Alcina Leite se revelado poetisa inspirada e culta distincta das letras. Saudamos enthusiasticos a illustrada preceptora alagoana, pedimos-lhe digne-se honrar-nos sempre com as

8 O referido poema integra a obra Campesinas (1889, p. 20), e trata da passagem bíblica, especificamente, o sofrimento de Maria diante do filho crucificado. Portanto, a frase em latim pode ser traduzida como "Tristeza materna”. 
mimosas produções de sua intelligencia brilhante (Gutenberg, 20 fev. 1881).

Em Recife, a autora de Campesinas publicou em o Lyrio, e em Laranjeiras (SE) o poema "O joaseiro". Com versos de feitura simples, aliada à melancolia e à tristeza, Alcina Leite transformava em poesia a solidão, o amor e a vida mortificada, de forma que seguia uma tradição poética do Oitocentos, ou seja, um lirismo que tinha um apelo quase confessional. No prefácio da obra, o tom intimista do poema anuncia uma vida de sacrifícios e mortificação, mas também as alegrias de quem vivia no campo, próximo à natureza: "Pobre visionaria, fiz da poesia a minha fada consoladora, a minha irmã d'alma, a doce amiga a quem confiei todos os meos segredos: não mais. Como toda gente, eu comprehendo as naturaes alegrias da mocidade, - turbulenta de rapazes, loquacidade de meninas, risadas crystallinas da infância”. Em meio aos versos estão algumas referências de nomes da literatura brasileira que indicam as leituras da ilustre professora, a exemplo de Gonçalves Dias, Laurindo Rebello, Thomaz Ribeiro, Casemiro de Abreu, Fagundes Varella e José de Alencar. A Julio Verne, ela dedica atenção em Alice (impressóes de leitura) (p. 41). O teor dos poemas e dos contos da professora alagoana pode nos indicar o perfil do magistério ou o viés confessional e romântico, quando passagens bíblicas são referenciadas, como a de Sta. Theresinha de Jesus e de Sto. Antonio de Lisboa, mas também poemas em homenagens, felicitações e dedicatórias a parentes e amigos, por ocasião de nascimentos, casamentos, aniversários e mortes.

Alcina Leite dedicou, em Campesinas, alguns de seus versos à colega de ofício e conterrânea, Maria Lucia, numa época na qual a autora do Almanaque das Senhoras era viúva. Em "Desilusões - á minha amiga d. Maria Lucia” (p. 74), Alcina Leite se apoia em passagem de Queiroz Ribeiro para homenagear a colega: "E a gente fica, entre abismado e louco, cheio de espanto e de tristeza e dó, 
ao ver que o pó era aquelle oiro há pouco, e ao ver que o oiro era somente ... pó”.

Raras vezes o universo escolar era transformado em poesia, o que pode soar estranho para alguém como Alcina, reconhecida como professora pública e próxima à infância nas aulas da escola primária feminina em Coqueiro Seco. Exceção encontra-se em "A primeira lição", em que a menina Laura recebe um presente: “Trouxe-lhe o pae, um dia, um livro lindo, um 'Alphabeto d'Ouro', e o anjo, rindo: 'Ensina-me a lição!' pede ao papá. Volve após n’um transporte de ventura. E diz à mãe, que chora de ternura: 'Olha, mamã, - eu já conheço o 'A'” (Coqueiro Seco, 27 de dezembro de 1888, p. 67).

Os dois ofícios, de fato, pareciam apartados nos impressos. $\mathrm{O}$ que teria Alcina Leite se apropriado da literatura para o magistério? Provavelmente não se terá facilmente tal resposta, mas, entre suas liras, há um perfil de modelos femininos destinados à contenção da dor e do sofrimento, em nome da família e de seu lugar socialmente demarcado. Portanto, as composições provavelmente serviam para exposição tanto de quem se encontrava em espaços socialmente demarcados e vigiados quanto de portadoras de valores morais na imprensa e na escola.

Aos anos de docência se seguia também o vínculo com o Instituto dos Professores Primários, que funcionava desde 18 de outubro de 1886, cujo propósito era auxiliar na formação dos professores e ofertar cursos e conferências públicas. Dois periódicos colaboravam: O Magistério e o 15 de Outubro. O irmão de Alcina, Antonio Leite', era um dos nomes da instituição, juntamente com

9 Antonio F. Leite Pindahyba era professor de escola pública primária em Atalaia, desde 1874. Ao publicar a obra Iris da Escola, ele pretendia que fosse adotada pela província para circular nas escolas primárias. Fato que não ocorreu: "Reprovado pela congregação do Liceu O Iris da Escola, nem mesmo o seu 
Francisco Domingos da Silva, diretor do IPP ${ }^{10}$. De propaganda abolicionista, o Instituto aproveitou os festejos dos 170 anos da Primeira Lei de Instrução Publica, de 15 de outubro de 1827, para realizar um ato simbólico: Alcina Leite, o irmão e a cunhada, também professora pública, alforriaram uma escrava de nome Monica, com 29 anos, para a qual foi entregue, na ocasião, a carta que a tornava livre ${ }^{11}$. O sentido de liberdade atribuído ao aniversário da lei de 15 de outubro de 1827, com a libertação da escrava, simbolizava a luta do IPP também para pôr fim a dois estigmas do Brasil-Império: o analfabetismo e a escravidão, ambos associados a um sentimento de vergonha nacional que atrasava a modernidade do país.

O falecimento de Alcina Leite provavelmente ocorreu em 1939, quando ainda publicava versos de conteúdo religioso no jornal maceioense Gazeta de Alagoas. Numa carta manuscrita enviada de Coqueiro Seco, em 9 de novembro de 1938, a autora de Campesinas se dirige ao colega Aminadab Valente: "O Sr. só me vê através d'aqueles versinhos a N. Senhora”. Além de queixar-se de seu frágil estado de saúde, responde à solicitação de elaborar um escrito sobre suas memórias "O seu gesto pedindo que lhe mande cousa da minha meninice para publicar não me anima, pois nasce da sympatia do Sr. e de suas irmãs pelas minhas tão simples composiçaozinhas, mas é que tudo agora já me cansa, quase não posso nem copiar".

autor, que é professor publico, o podia admitir em sala de aula" (O Orbe, 2 de julho de 1882, ano IV, n. 71, p. 1).

10 A professora pública Julia de Carvalho colaborava intensamente como IPP. Em 1888, O Magistério anuncia seu empreendimento na publicação de um Compêndio de Arithmética elementar. (Cf. O Magistério - órgão do Instituto dos Professores Primários - Revista Pedagógica, Scientifica, Litteraria e Noticiosa, ano II, Maceió, 15 fev. 1888).

11 Cf. O periódico 15 de Outubro, de 1886. Maceió, n. único, Comemorativo da Sessão Magna do Instituto dos Professores Primários das Alagoas, p. 4. 
Em tom de despedida, finaliza: "Confesso que já tive a lembrança de despedir-me das pessoas de minha amizade, quando me fosse possível ir a Maceió, e necessariamente teria de ir à casa do senhor". É cativante constatar o apego de Alcina Leite a Coqueiro Seco, pequena cidade próxima a Maceió, que, desde o ingresso no magistério e na literatura, não desejou deslocar-se para a capital, onde tantas pretendiam trabalhar e residir ${ }^{12}$.

\section{Maria Lucia: do Atheneu ao Almanack Litterario}

Colega de ofício e amiga de Alcina Leite, a educadora e escritora Maria Lúcia Romariz ${ }^{13}$ nasceu em Palmeira dos Índios (AL), em 13 de abril de 1863. Raras publicações se referem a ela, com exceção de algumas informações biobibliográficas de Izabel Brandão (2004): "Após terminar com distinção o curso do Liceu de Maceió, ela tentou matricular-se em uma das faculdades do país, sem sucesso" (p. 239). No volume 5 do Diccionario do baiano Augusto Victorino Sacramento Blake (1882) trata que, aos vinte anos, em fevereiro de 1883, o esposo Antonio de Almeida Romariz veio a falecer, fato que a deixou desprovida de meios para sobreviver, e a fundação do Atheneu se deu, provavelmente, por tal condição.

Da mesma forma que Alcina Leite, ela apareceu na imprensa na década de 1880, tendo seu nome relacionado ao magistério e à fundação de periódicos literários. Em 2 de julho de 1883, Maria Lúcia inaugurava o colégio Atheneu Alagoano, destinado ao ensino primário e secundário para meninas e jovens maceioenses.

12 Uma biografia completa de Alcina foi escrita pelo poeta e romancista alagoano Rodolpho Alves de Faria (1871-99), ainda ignorada (Barros, 2005).

13 Maria Lucia assinava, inicialmente, com o sobrenome do esposo falecido em fevereiro de 1883, Antônio de Almeida Romariz. Em novembro de 1889, ela passou a assinar Maria Lucia Duarte, em virtude do matrimônio com João Francisco Duarte. 
Concomitante à docência, a professora e literata investiu no universo literário quando fundou A Revista Alagoana (1887), em parceria com Rita Mendonça Barros Correia. No ano seguinte, foi a vez do Almanack Litterario Alagoano das Senhoras, destinado a divulgar a literatura feminina brasileira, com algumas inserções de escritores portugueses. Seu nome também recebeu aceitação em publicações de Lisboa, com a crônica dedicada ao poeta pernambucano J. Duarte Filho, "A primeira nuvem”, no Novo Almanch de Lembranças Luso-brasileira (1888, pp. 132-6). Com o mesmo tom melancólico de Alcina Leite, Maria Lucia expôs um perfil esperado de uma figura feminina do século XIX, qual seja, naturalmente inclinada ao sofrimento, à solidão, à resignação e ao abandono: "Não te illudas, pois; segue o teu caminho, deixa-me estacionar nas minhas trevas..." (Duarte Filho, 1888).

O formato do periódico português Novo Almanch de Lembranças Luso-brasileira deve tê-la inspirado a fundar em Maceió, no mesmo ano, o já mencionado Almanack Litterario Alagoano das Senhoras $(1888)^{14}$. No periódico, ela conseguiu reunir alguns nomes da literatura feminina brasileira e portuguesa, desde a escrita literária da própria Alcina Leite, à da jovem alagoana Maria Carolina Guerra Jucá, senhoras de várias províncias brasileiras, além de escritores portugueses, como Alice Moderno, João de Deus e Joaquim Pestana. No primeiro número do Almanack, Maria Lúcia publicou o poema "Saudade", no qual ainda lamentava a morte do esposo, ocorrida em 1883: "Longe d'aqui, bem distante, onde a estrella além brilhou... Foi-se o anjo que na vida Mil venturas me offertou" (p. 39).

Quanto à docência, o nome de Maria Lucia se vinculava ao ensino particular, tanto na condição de professora e proprietária de

14 Os dois exemplares de 1888 e 1889 , do referido periódico, encontram-se no acervo do IHGAL, contendo cada um mais de 150 páginas. 
um colégio para o público feminino quanto em outras instituições e em domicílio. Nos exemplares do Almanack de sua propriedade de 1888 e 1889, foram publicados anúncios nos quais ela oferecia os serviços de professora particular de Português, Geografia e Aritmética. Seu nome também se associava ao magistério particular em outros periódicos locais, entre os quais, o Almanack do Estado de Alagoas, para o ano de 1891, e o jornal A Fé Católica, em 13 de janeiro de 1906, do Collegio SS. Sacramento, onde ela foi professora de Português. A data de seu falecimento é desconhecida, mas, até maio de 1917, Maria Lúcia era mencionada em notas dos jornais de Maceión ${ }^{15}$.

Ao fundar o colégio, de nome Atheneu Alagoano, a autora do Almanack das Senhoras pretendia ofertar às jovens alagoanas a possibilidade de realizar um sonho seu interrompido: um curso superior. Tanto que uma das propostas do colégio era ministrar o ensino secundário com o intuito de preparar jovens para os cursos superiores do Império. Consta nos estatutos do colégio que se tratava de

[...] uma instituição particular de educação domestica e social e de instrução primaria e secundaria para o sexo feminino. [...] franqueará suas portas as senhoras que quizerem se habilitar nas matérias do Curso Normal para o magistério público primário, e às que pretenderem estudar os preparatórios exigidos nas Faculdades do Império (O Orbe, 3 jul. 1883).

Era, de fato, uma proposta ousada na província de Alagoas, em razão de os demais colégios femininos ofertarem apenas as primeiras letras e as prendas domésticas. Com essa iniciativa, a edu-

15 Em 12 de maio de 1896, o Gutenberg veiculou algumas notas sobre Maria Lucia na Câmara dos Deputados do Estado de Alagoas. Não se sabe ao certo se ela ocupava algum cargo naquela casa legislativa. 
cadora e literata pretendia elevar a condição da mulher à cultura letrada. Assim, consta no Art. 7. :

O Atheneu ofertará dois cursos: [...] um contendo as materias do curso normal, que são Portuguez, Arithmetica, Geographia, História do Brasil, Pedagogia, Chatecismo, Desenho Linear, para o magistério do sexo feminino, musica vocal, Piano e Dansa; [...] Outro secundário que compreende as Liguas Portugueza, Franceza e Ingleza, a Algebra, Geometria, História Universal, Desenho de paysagem, Calligraphia, Escripturação mercantil, e noções de sciencias naturaes, incluindo physica, chimica, botânica, zoologia, higiene, ensino de cousas, \&c ( O Orbe, 3 jul. 1883).

No século XX, a atividade de escritora e professora de Maria Lucia foi suplantada pelo papel de mãe e esposa, com práticas vinculadas à caridade cristã. Mas, sua filha Anna Sampaio Duarte tornou-se professora particular do Prytaneu Alagoano, por volta de 191716, ensinando artes e letras com Rita de Souza Abreu, o nome de batismo de Rosália Sandoval, professora alagoana, que teve uma escrita literária vigorosa até meados do século XX.

\section{Considerações finais}

Dado o limite deste texto, ele se coloca como os primeiros indícios de um trabalho de investigação entre literatura, magistério e imprensa no Brasil-Império. Tantas indagações nos ocorreram, particularmente, como o universo escolar se relacionava com a literatura, considerando o ofício das duas professoras? Alguns pontos podem ser conclusivos, a exemplo dos versos com apelo confes-

${ }^{16}$ Cf. Diario do Povo, 2 fev. 1917. 
sional, realçando a dor e o sofrimento femininos. Tal indicação põe o papel dessas mulheres no ordenamento da "cena pública", como nos adverte Neves (2009) sobre o alinhamento nas relações de poder nas mais variadas esferas sociais do Oitocentos.

Embora os vínculos parentais tenham sido decisivos para a inserção de ambas na imprensa periódica, as trajetórias de Maria Lucia e Alcina Leite representaram a expressão de um protagonismo no magistério primário, para o qual a escrita literária funcionou como proteção dos estigmas da sociedade patriarcal, pois ganharam poder de expressão pública, se comparada com a grande parcela de decentes ausentes desses espaços da palavra impressa. Os versos contidos, que anunciavam uma vida silenciada e subjugada à figura masculina, não condiziam com o fato de terem insurgido como figuras ímpares naquele cenário de relações profundamente hierarquizadas.

\section{Referências}

ANDRADE, Debora E. In ENGI, M. G. et al. (orgs.). Os intelectuais e a imprensa. Rio de Janeiro: Mauad X: Faperj, 2015, pp. 13-47.

BARROS, Francisco Reinaldo A. ABC das Alagoas: dicionário biobibliográfico, histórico e geográfico de Alagoas. Brasília: Senado Federal, 2005.

BLAKE, Augusto Victoriano Alves Sacramento. Diccionario Bibliografico Brazileiro. Rio de Janeiro: Typ. Nacional, 1882.

BOTO, Carlota. "O professor primário português como intelectual: Eu ensino, logo existo”. Revista da História das Ideias, v. 24, pp. 85-134, Faculdade de Letras de Coimbra, 2003.

BRANDAO, I. F. O. "Maria Lúcia Duarte". In MUZART, Zahidé Lupinacci (org.). Escritoras brasileiras do século XIX. 1 ed. Florianópolis: Mulheres/Sta. Cruz do Sul: Edunisc, 2004, v. II, pp. 239-46. 
LAVENERE, Luis. Almanack Alagoano das Senhoras: litterario, histórico e estatístico para 1904. Maceió: Livraria Fonseca, 1904.

LEITE, Alcina Carolina. Campesinas. Maceió: Typ. de Amintas de Mendonça, 1889.

NEVES, Lúcia M. Bastos Pereira das (org.). Livros e impressos: retratos do Setecentos e do Oitocentos. Rio de Janeiro: EdUERJ, 2009.

ROMARIZ, Maria Lucia. Almanack Litterario Alagoano das Senhoras para 1889. Maceió: Typ. Novo-Mundo, 1889, ano II.

. "A primeira nuvem - ao festejado poeta pernambucano J. Duarte Filho". Novo Almanach de Lembranças Luso-brasileiro para o ano de 1888. Lisboa: Livraria Antonio Maria Pereira, 1887, pp. 132-4.

. Almanack Litterario Alagoano das Senhoras. Maceió: Typ. de Antonio

Luís \& Cia., 1888, ano I.

SCHUELER, Alessandra Frota M. de. "Professores primários como intelectuais da cidade: um estudo sobre produção escrita e sociabilidade intelectual (Corte Imperial, 1860-1889)". Revista de Educação Pública, n. 17, Universidade Federal do Mato Grosso, 2008. 


\title{
THOMAZ ESPINDOLA E A GEO- GRAFIA ESCOLAR DO IMPÉRIO BRASILEIRO
}

\author{
Uma análise do compêndio Elementos de \\ Geografia e Cosmografia oferecidos à \\ mocidade alagoana $(1885)^{\prime}$
}

Edgleide de Oliveira Clemente da Silva

\section{Introdução}

Este capítulo particulariza uma reflexão acerca da terceira edição do compêndio Elementos de Geografia e Cosmografia oferecido à mocidade alagoana $(1885)^{2}$, destinado aos alunos do Liceu (criado em 1849) e da Escola Normal de Maceió (criada em1869). Essa obra foi publicada pelo médico alagoano Thomaz do Bomfim Espindola (1832-89), o qual se tornou um expoente intelectual, consultado para propor mudanças no ensino brasileiro por meio da elaboração dos pareceres da "Reforma do ensino primário e vá-

1 Versão modificada do texto apresentado no VII Congresso Brasileiro de História da Educação. Cuiabá, UFMG, 20 a 23 de maio de 2013

2 A primeira edição desse compêndio foi lançada no ano de 1860 pela editora de TVP da Gazeta de Notícias de Maceió. Também destaco que, diante do extenso título da obra, por vezes, ela será mencionada ao longo do texto como: Elementos de Geografia (1885). 
rias instituições complementares da instrução pública” (1882) e da "Reforma do ensino secundário e superior" (1883), juntamente com Rui Barbosa e Ulysses Vianna.

Thomaz Espindola concluiu o curso de Medicina e Cirurgia na Bahia, em 1853, com a tese Dissertação inaugural acerca da influencia progressiva da civilização sobre o homem. Em 1858, assumiu interinamente a cadeira de Geografia, Cronologia e História no Liceu alagoano, atuando também como professor de Higiene do Liceu de Artes e Ofícios, fundado em 1884. Além de exercer o cargo de professor, Espindola foi diretor geral de estudos por três anos consecutivos, de 1866 a 1868. Na condição de político e integrante do Partido Liberal de Alagoas, ocupou os cargos de deputado provincial entre os anos de 1860-61, 1864-65 e 1866-67, e de deputado geral nas legislaturas de 1878 a 1881 e de 1881 a 1884. Ainda no cenário político, chegou a atuar como presidente interino da província de Alagoas, nos mandatos de 1867 e 1878.

$\mathrm{Na}$ condição de médico ${ }^{3}$, publicou a obra Profilaxia do "colera morbus" epidemico: sintomas, tratamento curativo desta molestia, dieta, convalescencia, considerações gerais e clinicas (1862), e, durante a ocupação do cargo de diretor geral de estudos, escreveu os Relatórios da instrução publica e particular da provincia das Alagoas (1866, 1867 e 1868), nos quais avalia a situação escolar de Alagoas ${ }^{4}$. Há também a obra geográfica Geografia alagoana ou des-

3 Nesse campo, ocupou os cargos de Inspetor de Saúde Pública e Provedor do Porto, Comissário Vacinador e Médico Consulente do Hospital Regional de Maceió.

4 No cargo de inspetor geral de estudos, cabia a Espindola sistematizar os dados de todas as escolas particulares e públicas alagoanas e encaminhá-los ao presidente da província, constituindo duas formas de avaliar a educação: a importância do lugar social ocupado e da história de vida de cada um. 
criçäo fisica, politica, historica da provincia das Alagoas, publicada em duas edições (1860 e 1871).5

Atualmente, tem-se produzido um número expressivo de publicações sobre a análise histórica de determinados livros didáticos no Brasil, estejam eles concentrados no período Imperial ou Republicano, os quais considero importantes fontes de pesquisa para se compreender como, quando e de que forma os saberes circulavam dentro e fora da escola. Como afirma Corrêa (2000, p. 13), os livros didáticos funcionam como "veículos de circulação de ideias que traduzem valores", supostamente capazes de modelar os sujeitos.

Segundo Espindola (1885), a terceira edição da obra Elementos de Geografia estava "mais correcta e de accordo com os progressos da ciência" (p. 4). O que significa dizer que o saber geográfico contido em sua escrita cumpria uma dupla função: preparar os sujeitos para zelarem pela integridade geográfica do país, estabelecendo uma relação íntima com o poder político; e absolutizar a ciência geográfica como modeladora das demais ciências que despontavam à época, fossem elas humanas, físicos ou naturais, colocando-a na condição de saber único e verdadeiro.

Portanto, o objetivo deste capítulo é compreender qual era $\mathrm{o}(\mathrm{s})$ saber(es) geográfico(s) veiculado(s) na obra citada. Para tanto, utilizo as contribuições de Vesentini (1994), Rocha (1996), Tonini (2003) e Pessoa (2007) sobre a história da Geografia, a fim de compreender como esse conhecimento surge e ganha espaço nas escolas, desde a Antiguidade, com a denominação de Geografia Clássica, até a sua consolidação como Geografia Moderna.

5 Segundo Barros (2005, p. 541), Espindola também é autor de dois relatos de viagens, os quais ainda não foram encontrados. São eles: "Descrição das viagens do Dr. José Bento Cunha Figueiredo Júnior ao interior da Provincia de Alagoas" (1870) e "Viagem do Presidente da Provincia Francisco de Carvalho Soares Brandão a Povoação de Piranhas e Paulo Afonso" (1878). 
Desse modo, o texto está desenvolvido em três tópicos. No primeiro, apresento um breve estudo da trajetória intelectual de Thomaz Espindola e sua relação com o campo da educação e da política, o que possivelmente influenciou na escrita da sua obra e o destacou como autor. No segundo tópico, abordo quais eram os principais conhecimentos geográficos defendidos por ele e para quem eram destinados. $\mathrm{Na}$ última parte, detive-me a analisar o capítulo "Geografia Política", de sua obra Elementos de Geografia, no qual ele apresenta as noções de civilização e nação.

\section{A trajetória intelectual de Thomaz Espindola}

A escrita dos homens do Império era marcada por uma larga formação intelectual de cunho humanístico. A produção de uma obra didática não tocava apenas nas especialidades de uma área, mas num conjunto delas, desde cultura, religião, política e educação até os aspectos mais instrucionais dirigidos aos professores. Essa vasta formação intelectual também era reflexo do lugar social que autores como Thomaz Espindola ocupavam nas províncias, a exemplo de suas simultâneas funções como médico, professor e político.

A interpretação das questões sociais da província das Alagoas passava pela escrita de alguns poucos homens de letras que, não por acaso, pertenciam à elite econômica e política de Alagoas. Eram esses senhores letrados que também faziam parte do professorado liceísta, adquirindo privilégio na publicação de compêndios e periódicos. Espindola também fazia uso da prerrogativa de principal redator do jornal $O$ Liberal, fundado em 12 de abril de 1869 , no qual publicava suas ideias sobre a escolarização alagoana (Barros, 2005, p. 542).

Suas reflexões atraíram admiradores, a exemplo do historiador Lima Junior (1972, p. 1), que o considerava "homem austero, culto, brilhante, de aprimorada educação”. Sua forte influência no cená- 
rio sociopolítico da província alagoana serviu de referência para as camadas mais elitizadas da época: “[...] ele era a expressão clara do intelectual de sua época, chamado a falar e a ocupar os mais diversos lugares no corpo social, assim se compreende a condição de professor, médico, geógrafo, historiador, inspetor e parlamentar" (Madeira e Silva, 2011, p. 7).

$\mathrm{Na}$ Assembleia Provincial, Espindola envolveu-se na defesa da não extinção do Liceu alagoano, no qual foi lente de Geografia

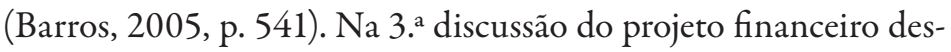
sa mesma Assembleia, o jornal Diário das Alagoas, de 19 de julho de 1861, publicou as considerações de Espindola sobre o ensino de Geografia:

Senhor presidente, tratando de demonstrar a grande utilidade da geographia, disse-o o dr. Pompeo, e disseram muitos outros litteratos: 'Assim como a historia nos faz contemporaneos de todos os sucessos e de todos os grandes homens, a geographia nos faz cosmopolitas ou concidadãos de todos os povos: Ella é peristilo dos conhecimentos humanos, a porta que dá entrada para o mundo civilizado. E Cousin disse-o: - Dái-me a carta de um paiz, sua configuração, seu clima, suas águas, seus ventos e toda a sua geographia physica; informai-me de suas producções naturais, de sua flora, de sua zoologia \&c.; e eu me comprometo a dizer-vos a priori qual será o homem desse paiz e que lugar gozará na historia, não accidental, mas necessariamente, não em tal epoca, mas em todas as epocas; enfim a idea de que este paiz é destinado a representar' (n. 163).

Espindola foi um grande defensor da permanência das cadeiras de Geografia, História e de Língua Inglesa, com o argumento de que, por meio desses saberes, o aluno poderia melhor aproveitar os conhecimentos "úteis" para a vida cotidiana. Como prova de 
sua assertiva, menciona dois autores, Pompeo e Cousin. O primeiro foi Thomaz Pompeo de Souza Brasil, bacharel em Direito, primeiro diretor do Liceu do Ceará, professor de História e Geografia, e autor de vários manuais dessas áreas, em especial, o de 1851, Elementos de Geographia, que se transformou, em 1856, no compêndio de Geographia adotado pelo Colégio Pedro II e demais liceus e seminários do Império (Sousa Neto, 1997). O segundo, chamado Victor Cousin, era um filósofo francês, conhecido pelo seu sistema "ecletismo espiritualista", o qual "foi adotado como filosofia oficial no Colégio Pedro II", servindo de referência para as demais escolas brasileiras de ensino secundário, a exemplo do Liceu alagoano (Saviani, 2008, p. 118).

Entre outros debates, sugeriu a revogação da lei de vitaliciedade dos cargos de diretor e vice da Diretoria da Instrução Pública e dos professores substitutos. Sugeriu também o cumprimento da legislação que determinava o concurso para as cadeiras do Liceu, bem como a organização e regulamentação das escolas primária e secundária. Lamentou o caráter disciplinar dessas escolas ao afirmar que o gosto pelo desenvolvimento intelectual não era o elemento mais importante. Para tanto, lembrou a importância de se criarem leis que cercassem de garantia os alunos do Liceu contra o abuso da autoridade dos mestres.

Reclamou do ensino primário por carecer de métodos e livros didáticos e não ter mais por que apelar para a leitura de Camões nas aulas do sexo feminino, como rotineiramente acontecia em suas visitas às escolas, ressaltando que era preciso despertar nas jovens o gosto pela ciência e pelos estudos que interessavam à sociedade na qual viviam.

Espindola asseverava que o ensino era "feito a talante dos professores" e citava numerosas lacunas nos processos pedagógicos (1886, p. 3). Por conta disso, estabeleceu algumas solicitações: a instalação imediata da Escola Normal; a decretação de um novo regulamento interno; o estabelecimento e a uniformização de um 
método de ensino; a divisão do tempo escolar; a eficiência nas inspeções das escolas; a adoção de compêndios previamente escolhidos pela Inspetoria Geral; uma maior propagação da instrução primária, tornando-a, de alguma sorte, obrigatória; o estabelecimento de caixas de beneficência e o auxílio ao ensino particular.

Mesmo após tais exigências, asseverava que as aulas de instrução primária, o programa de ensino e a distribuição do tempo e do trabalho não haviam sido alterados: "Vão sendo postos em execução, não com a desejada restricção, mas com alguma morosidade; porque as inspecções não tem sido feitas com rigor e assiduidade; e porque os professores em geral desconhecem os verdadeiros princípios de pedagogia" (Alagoas, 1868, p. 2).

Thomaz Espindola faleceu no dia 6 de março de 1889 como um dos destacados homens de letras da província das Alagoas, deixando marcas no cenário educacional alagoano como crítico das práticas de uma escola de tradição jesuítica que primava mais pela disciplina de comportamento do que pelo gosto no conhecimento.

Além disso, tornou-se referência na sistematização do saber geográfico em Alagoas, expondo temas como o solo, o clima, a fauna e a flora. Esses aspectos geográficos passariam a definir o caráter humano, baseado nos postulados de uma ciência considerada chave para a configuração do poder político e econômico. Com esse propósito, a Geografia precisava circular na forma de saber didático nas escolas provinciais brasileiras, como veremos adiante.

\section{Espindola e o conhecimento geográfico nos ensi- nos primário e secundário}

A terceira edição do compêndio Elementos de Geografia e Cosmografia oferecido à mocidade alagoana é composta por 333 páginas e foi lançada no ano de 1885. Segundo Duarte (1947, p. 50), essa obra "foi escrita com o propósito de atender às necessidades do ensino da matéria no então Liceu de Maceió, de cujo corpo do- 
cente fazia parte o seu autor, na qualidade de lente catedrático de Geografia, História e Cronologia, e apareceu em 1860, sendo reeditada em 1871".

A referida obra está dividida em três partes, com cerca de setenta capítulos, distribuídos em temas relacionados à descrição dos espaços geográficos (clima, solo e vegetação) de todos os países. A primeira parte foi nomeada de "Preliminares", que trata dos princípios gerais da ciência, os quais estão relacionados ao conhecimento da Geografia Geral. Já a segunda parte descreve os aspectos físicos, políticos, econômicos e sociais dos continentes da Europa, Ásia, África, América e Oceania.

Springer (2009, p. 21) afirma que essa organização metodológica da obra de Espindola se assemelha à do alemão Alexander Von Humboldt (1769-1859)6 , que dividia a Geografia em "Geografia Geral" e "Geografia Especial”, sendo a primeira destinada ao "estudo geral da Terra em seus aspectos naturais e sociais, que seriam observados e analisados em uma sequência de sete áreas pelo globo terrestre", e a segunda "desenvolveria o conhecimento sobre os países, cada um estudado e analisado em separado com suas particularidades".

Segundo Tonini (2003, p. 34) os estudos de Humboldt contribuíram para a construção da Geografia Moderna, o que proporcionou "mais cientificidade nas análises geográficas ao buscar uma totalização, uma generalização, uma universalização dos fatos, enfim um encontro com a Modernidade”. Pratt (1999, p. 213) também adverte a contribuição desse alemão para o surgimento dessa nova concepção de Geografia:

${ }^{6}$ Esse viajante era considerado uma "pessoa de extraordinário vigor, habilidade e ilustração, estruturou suas próprias jornadas e temas de estudo e despendeu em sua efetivação a energia de uma vida inteira. Tanto suas viagens quanto seus escritos assumem uma proporção épica a que ele devotou sua vida e fortuna para criar" (Pratt, 1999, p. 203). 
Ele apresentou tentativas inovadoras de corrigir o que considerava como as falhas do relato de viagem de seu tempo: por um lado, uma preocupação irrelevante com o que chamava de o 'meramente pessoal', e, por outro, um acúmulo de detalhes científicos que eram espiritual e esteticamente enfraquecidos. [...] A vivacidade da descrição estética, de que ele estava convencido, seria complementada e intensificada pelas revelações científicas das 'forças ocultas' que moviam a natureza.

Dessa forma, a contribuição dos escritos de Humboldt foi importante para a realização de mudanças na formalização da Geografia, uma vez que a referida disciplina, no final do século XVIII, instituiu-se num trunfo poderoso para governos nacionais e aqueles que precisavam demarcar territórios e conceitos de nação para seus respectivos países.

A terceira parte da obra é designada "População do globo", na qual é abordada a política de cada continente. Integrada nessa terceira parte, há a "Geografia Particular do Brasil", subdividida em duas seções: "física” e "política”. O último tópico dessa terceira parte nomeia-se "Geografia Matemática" ${ }^{7}$ que trata da Cosmografia brasileira, considerada por Espindola a mais complexa.

Entre os elementos marcantes que encontramos na obra Elementos da Geografia (1885), é a rica descrição da natureza, do solo, da topografia e dos diferentes conhecimentos sociais acerca dos continentes. Para Espindola, essas descrições comportavam especificida-

7 Segundo Rocha (1996, p. 131), a Geografia matemática é uma “concepção de Geografia cuja principal característica era a forte influência exercida pelas ciências matemáticas sobre ela, o que explica o fato de que, em conexão com os ensinamentos acerca das considerações gerais sobre a Terra, fossem também ensinadas a astronomia, a cosmografia e a cartografia, bem como a geometria”. 
des, que deveriam ser ensinadas de acordo com o nível/grau de cada aluno. Por isso deixa claro para os alunos da Escola Normal quais eram os assuntos geográficos indispensáveis para a sua formação:

Advirto, porém, que os alumnos da Eschola Normal não devem ser obrigados a aprender da Geographia propriamente dita mais do que aquillo que contem no Atlas elementar para o uso das aulas primarias pelo Dr. João Eislão da Silva Lisboa; também como não devem ser obrigados a aprender a superfície de todos os países do mundo, nem o nome de todas as cidades mencionadas nesta obra; basta que não ignorem a superfície dos países mais notáveis da Europa e América e que entre as cidades decorem os nomes das capitais e de uma ou outra cidade mui notável, como, por exemplo, nos Estados-Unidos do N. além da capital as cidades de New York, Philadelphia e Boston; na Inglaterra além das capitais do reino, da Irlanda e Escossia as cidades de Licerpool, Menchester e Glascoro. (Espindola, 1885, p. 3).

Qual o saber geográfico deveria constar na formação do professor primário? Verifica-se que, nesse ponto, a formação docente nas séries iniciais está relacionada ao conhecimento "útil". Para os professores em formação, o mais importante era memorizar o nome das principais cidades dos países considerados civilizados. Essa advertência indica que os alunos da Escola Normal deveriam somente aprender o que se considerava essencial para o seu grau de instrução.

Um ano após a publicação dessa obra, Espindola continuava preocupado quanto à formação docente em Alagoas e escreveu no relatório sobre a instrução pública e particular da referida província que os professores "vão servindo sem a precisa aprendisagem que os habilite ao ensino” (Alagoas, 1866, p. 3). Segundo Costa 
(1931, p. 15), essa crítica de Espindola "ficára surdo" ao poder público por longos anos.

Já com relação ao saber geográfico destinado aos alunos dos cursos preparatórios era extenso e completo, pois os preparava para a frente do comando. O conhecimento do "lugar" ajudava a estabelecer estratégias de dominação, noção que precisa ser bem empregada nos momentos de conflitos. Portanto, no próximo tópico buscaremos esboçar quais conhecimentos geográficos estavam presentes na referida obra didática e se esses assuntos condiziam com a realidade brasileira.

\section{Geografia Política: a perspectiva de nação e civilização de Espindola}

No século XIX, o saber geográfico se propagava por meio dos conceitos, que ganhavam solidez com os experimentos, e por meio das atividades de campo, nas quais o homem era estudado como um elemento a mercê da natureza (Madeira e Silva, 2011).

Nessa época, os livros brasileiros de Geografia seguiam uma linha teórico-metodológica centrada nas experiências e nas observações dos fenômenos. Duarte (1947, p. 58) aponta que, "ainda neste período, predomina o sentido ou o gosto pela descrição, sem se descer à compreensão das influências do meio físico sobre o homem". Desse modo, a Geografia nasce por meio de traços descritivos, orientando o jovem a ser um mero observador que enumerava e classificava os objetos estudados. Essa perspectiva pode ser claramente percebida quando Espindola (1885, p. 42) busca definir o que é "nação":

MESTRE - O que é nação?

DISCIPULO - Esta palavra tem tres accepções; uma geographica, outra ethnographica e outra politica.

Segundo a geographica dá-se o nome de nação a todos os habitantes de uma região que tem limites naturaes indepen- 
dentes das divisões politicas a que pertencem e das linguas que fallam; por exemplo, os indios, que chamam-se todos os habitantes comprehendidos entre Himalaya, o oceano Indico, o Indo e o Ganges.

Segundo a ethnographica dá-se o nome de nação aos habitantes de uma região qualquer, os quaes fallam uã mesma lingua e seus diversos dialectos independente das grandes distancias que os separam, das divisões politicas a que pertencem, da religião que professam, e do estado de civilisação em que se acham; por exemplo, os hespanhoes espalhados pelo globo. Finalmente segundo a politica dá-se o nome de nação a uma quantidade grande de familias, que habitam um determinado terreno, e vivem sujeitas ao mesmo supremo governo.

Nessa passagem, não somente se pode avaliar a distinção entre o que seria uma "nação", como também o modelo metodológico utilizado na obra. Esse procedimento é chamado de "método dialogístico", por se tratar de um diálogo fictício entre o mestre e o discípulo, elaborado por meio de perguntas e respostas. $\mathrm{O}$ mestre é aquele que pergunta e transmite o conhecimento, e o discípulo, aquele que responde e apreende o que lhe foi ensinado.

Era comum à época os livros didáticos, especialmente da área da Geografia e da História, serem organizados como uma espécie de catecismo. Esse método foi utilizado por Thomaz Pompeo de Souza Brasil em seu livro "'Geografia Geral e Especial do Brasil', editado pela primeira vez em 1856 e considerado um dos raros livros de Geografia dessa época, é por muito tempo o mais aceito e o mais divulgado compêndio didático" (Pessoa, 2007, p. 34). De acordo com Rocha (1996, p. 167), apesar do autor propor nesse compêndio um estudo sobre a Geografia do Brasil, ele se "dedica aos estudos generalistas sobre os diferentes países do globo”, portanto definindo-a como "uma Geografia meramente descritiva, 
sem preocupação nenhuma com uma análise científica dos fenômenos abordados".

Tal conhecimento descritivo desempenhou uma importante função na composição do que se entendia por nação (Vesentini, 1994, p. 33). Foi a partir de discursos nacionalistas que se criou uma acentuada exaltação à pátria, cujo modelo se centrava nos países europeus:

$\mathrm{M}$ - Como se classificam os povos segundo o seu progresso material, intellectual e aperfeiçoamento moral?

D - Em selvagens, barbaros e civilizados.

$\mathrm{M}$ - O que são povos selvagens?

$\mathrm{D}$ - São os que ignoram ou conhecem mui imperfeitamente a arte de escrever e as outras mais necessarias á vida; mantem o menor numero de relações com outros povos; e em geral são dados á pesca, caça ou pastoricia; vivem n'um estado nômade e pugnando pela liberdade natural: alguns são ate antropophagos, ou comem carne humana.

$\mathrm{M}$ - O que são povos barbaros?

D - São os que conhecem a arte de escrever e as outras mais necessárias a vida e não tem lingua polida, nem legislação bem conhecida; dão grande apreço a profissão da guerra e pouco ao estudo e aperfeiçoamento das sciencias e artes.

$\mathrm{M}-\mathrm{E}$ civilisados?

D - São os que teem lingua polida, legislação bem conheci$\mathrm{da}$, governo activo e previdente; teem em grande estima as sciencias e artes, marchando o seu progresso material e intellectual, mais ou menos, a par do aperfeiçoamento moral. M - Quantas especies de civilisação há no globo? D - Duas: a europeia e a asiatica, ambas as quaes distinguem-se entre si pela sua moral, usos e costumes (Espindola, 1885, pp. 41-2). 
Se antes as distinções e separações dos povos "se faziam pelas localizações geográficas - povos das montanhas; das planícies; dos platôs; das ilhas; dos rios -, agora, para justificar as divisões, insere-se outro elemento, elaborado no discurso de Ratzel: o nível de desenvolvimento" (Tonini, 2003, p. 46). Esse desenvolvimento significava situar as demais culturas numa escala hierárquica de desenvolvimento social.

Nessa perspectiva, a civilização é um processo, um estado, o estágio final da evolução de um povo que, num dado momento, foi considerado selvagem ou bárbaro. Nesse caso, "em comparação com a perfeição do polido [civilizado], o bárbaro é uma espécie de criança, a criança é uma espécie de bárbaro" (Starobinski, 2001, p. 28). A palavra "polir" implica um devir, uma ação progressiva, daí sua equivalência com "civilizar". Sendo "polidez" o nome de uma qualidade, e não de uma ação, ao passo que "civilização" poderá designar o processo transformador. "Polir é civilizar os indivíduos, suas maneiras, sua linguagem” (Starobinski, 2001, p. 29). Civilizados? "São os que teem lingua polida".

De acordo com Espindola (1853, p. 4), "entre os povos civilizados as guerras são benignas". Isso "significa dizer que o serviço ou a defesa da civilização poderão, eventualmente, legitimar o recurso à violência. $\mathrm{O}$ anticivilizado, o bárbaro devem ser postos fora de condição de prejudicar, senão podem ser educados ou convertidos" (p. 33). Essa relação hierárquica entre selvagem, bárbaro e civilizado, respectivamente, revela a barbárie que há nas civilizações, legitima a colonização e a exploração, e camufla a "falsa civilização" que há na selvageria habitual dos homens.

Portanto, as concepções mais exploradas na obra circundam em torno da formação do povo, o que era um elemento essencial nesse processo de busca pela civilização. Dessa forma, "as crianças deveriam ser moldadas, disciplinadas e retiradas do estado de barbárie em que se encontravam" (Malachen, 2006, p. 7). Seja por meio de bases tradicionais ou modernas a Geografia que nasce 
com o objetivo de auxiliar na construção do Estado-Nação, será manipulada nos livros didáticos a favor da instauração de um modelo civilizatório, religioso e nacionalista. Assim, os saberes geográficos que integravam a obra Elementos da Geografia (1885) giravam em torno dos conceitos de civilização, moral, religião, território, lugar e progresso material, assuntos caros à época Imperial.

Nesse sentido, tendo em vista um modelo ideal de civilização, o Brasil se encontrava inferior à Europa e aos Estados Unidos nos diferentes aspectos: moral, material, econômico, político, social, cultural. Isso nos ajuda a compreender o porquê da Geografia se iniciar com o estudo da Cosmografia (o global) e finalizar com o estudo da Corografia (o local). Essa organização metodológica entre macro e micro nos mostra o estilo comparativo, evolutivo, da Geografia. Comparativo quando se busca destacar as diferenças, mais do que as aproximações entre os continentes, e evolutivo quando classifica os povos segundo um modelo, um exemplo, um padrão, uma única referência.

Diante do exposto, os saberes veiculados na referida obra tendem a ressaltar o ideário já consolidado à época: que o continente europeu e os EUA eram intelectualmente superiores aos demais continentes, nos aspectos tanto da natureza e das marcas estéticas (cor, estatura, espessura e cor de cabelo) quanto políticos (civilização, nação) e econômicos (comércio e indústrias). Compreende-se assim que, em nome de um status de "civilizado", buscou-se, a partir da disciplina de Geografia, abolir o que se considerava ser uma degeneração material, intelectual e moral do país.

\section{Considerações finais}

A intensa atuação de Thomaz Espindola nos diferentes cenários da sociedade, como médico, professor, ordenador e político, mostra que a escola estava aliada a um projeto civilizatório a ser desenvolvido por meio dos investimentos na formação docente, da 
aprendizagem de novos métodos de ensino, da estruturação de um currículo ativo e da apropriação de saberes considerados úteis, a exemplo da Geografia.

Com o poder de influenciar as decisões políticas na província das Alagoas, esse alagoano conseguia sintetizar ou captar com sua escrita os desejos de mudança daquele grupo que pretendia consolidar nas escolas o saber originário da Ciência Moderna. Ademais, a interpretação do postulado científico sofria a interferência do lugar social e da posição política de tal modo que o modelo "metodológico dialogístico" parece nos inquietar sobre onde residia a modernidade na Geografia. No entanto, era possível que os resultados de estudos baseados na observação, na descrição e na experimentação despertassem no aluno o seu "chamado", progredir o povo, salvar a nação da barbárie.

Os efeitos desse saber geográfico no âmbito escolar trouxeram à circulação um saber que tematizava a imagem de progresso material, intelectual e moral na língua, na legislação, no governo, nas ciências e nas artes. Ao território brasileiro, restava ressaltar a grandiosidade territorial e as belezas paisagísticas que poderiam transformar o país numa nação que caminharia para o progresso material.

\section{Referências}

ALAGOAS. Relatorio da Instrucção publica e particular da Provincia das Alagoas: apresentado ao Exm. Srn. Dr. Esperidião Eloy de Barros Pimentel, presidente da Provincia pelo Dr. Thomaz do Bomfim Espindola. Maceió: Typ. da Gazeta de Notícias, 1866.

- Relatorio da Instrucção publica e particular da Provincia das Alagoas: apresentado ao Exm. Srn. Dr. Antonio Moreira de Barros, presidente da Provincia, pelo Dr. Thomaz do Bomfim Espindola. Maceió: Typ. do Jornal Alagoano, 1868. 
BARROS, Francisco Reinaldo Amorim de. ABC das Alagoas: dicionário bibliográfico, histórico e geográfico das Alagoas. Brasília: Senado Federal, Conselho Editoral, 2005.

CORRÊA, Rosa Lydia Teixeira. "O livro escolar como fonte de pesquisa em História da Educação”. Cadernos Cedes, ano 20, n. 52 , nov. 2000 .

COSTA, Craveiro João. Instrução Pública e Instituições Culturais em Alagoas. Maceió: Imprensa Oficial, 1931.

Diário das Alagoas, n. 163, Maceió, 19 jul. 1861.

DUARTE, Abelardo. A primeira Geografia alagoana: em torno do centenário da sua publicação, Revista do Instituto Histórico e Geográfico de Alagoas, 1945/1946. Maceió: Imprensa Oficial, 1947, v. 24.

ESPINDOLA, Thomaz do Bomfim. Dissertação inaugural acerca da influencia progressiva da civilisação sobre o homem. Salvador, 1853.

. Geografia alagoana ou descrição fisica, politica, historica da provincia das Alagoas. 2 ed. Maceió: Typ. do Liberal, 1871.

- Elementos de Geografia e Cosmografia oferecidos à mocidade alagoana. 3 ed. Maceió: Typ. da Gazeta de Notícias, 1885.

LIMA JÚNIOR, Félix. "Discurso pronunciado na Catedral de Maceió, em 2 de dezembro de 1969”. Revista do Instituto Histórico e Geográfico de Alagoas, v. 29, pp. 67-8, Maceió, 1972.

MADEIRA, Maria das Graças de Loiola e SILVA, Rosemeire Reis da. "Thomaz Espíndola: um liberal do império e seus escritos sobre a renovação da escolarização alagoana”. Anais do VI Congresso Brasileiro de História da Educação. Vitória: UFES, 2011, pp. 1-12. 
MALANCHEN, Julia et al. "A educação e o discurso da ordem no Brasil". Anais do VI Seminário Nacional de Estudos e Pesquisas. Campinas: UNICAMP, 2006. Disponível em: http:// www.histedbr.fae.unicamp.br/acer_histedbr/seminario/seminario7/. Acesso em: 21 jan. 2013.

PESSOA, Rodrigo Bezerra. Um olhar sobre a trajetória da Geografia escolar no Brasil e a visão dos alunos de ensino médio sobre a Geografia atual (dissertação). Universidade Federal da Paraíba, 2007.

PRATT, Mary Louise. "Alexander Von Humboldt - a reinvenção da América". Os olhos do Império: relatos de viagem e transculturação. Bauru: EDUSC, 1999, pp.195-247

ROCHA, Genylton Odilon Rêgo da. A trajetória da disciplina Geografia no curriculo escolar brasileiro (1837-1942) (dissertação). Pontifícia Universidade Católica de São Paulo, 1996.

SAVIANI, Dermeval. História das ideias pedagógicas no Brasil. 2 ed. Campinas: Autores Associados, 2008.

SOUSA NETO, Manoel Fernandes de. Senador Pompeu: um geógrafo do poder no império do Brasil (dissertação). Universidade de São Paulo, 1997.

SPRINGER, Kalina. "Considerações acerca da Geografia de Alexander Von Humboldt: teoria, filosofia e concepção de natureza”. Revista RA'EGA, n. 18, pp. 7-22, Curitiba, 2009.

STAROBINSKI, Jean. As máscaras da civilização: ensaios. São Paulo: Companhia das Letras, 2001.

TONINI, Ivaine Maria. Geografia escolar: uma história sobre seus discursos pedagógicos. Ijuí: Ed. Unijuí, 2003.

VESENTINI, José William. "Geografia crítica e ensino". In: OLIVEIRA, Ariovaldo Umbelino de (org.). Para onde vai o ensino de Geografia? São Paulo: Contexto, 1994, pp. 30-8. 


\title{
REVISITANDO ARTHUR RAMOS
}

\author{
A cultura negra e o debate da educação e seu \\ poder de correção e controle social na década de \\ 1930
}

Monica Luise Santos

\section{Introdução}

Nascido na cidade do Pilar, em Alagoas, em 1903, Arthur Ramos iniciou seus estudos primários em sua cidade natal e os completou em Maceió. Segundo Gaspar (2010), já como estudante da Faculdade de Medicina da Bahia, começou a publicar nos jornais de Alagoas e da Bahia artigos sobre o folclore, entre eles estão: $O$ culto da lua na história e no folclore, Tradiçôes africo-brasileiras (1922), A poesia popular(1924) e A ciência do folclore (1924). Ramos dedicou grande parte de sua vida aos estudos sobre o negro e a identidade brasileira.

Nos anos de 1930 e 1940, falar da cultura negra no Brasil era, de certo modo, atravessar as obras escritas por esse antropólogo e médico brasileiro, de cujo conjunto de sua vasta produção se sobressaem os escritos sobre a cultura e a religiosidade da etnia negra. Dentre suas produções sobre essa temática, destacam-se: $O s$ horizontes misticos do negro da Babia (1932); O negro brasileiro: etnografia religiosa e psicanálise (1934); O folclore negro do Brasil: demopsicologia e psicanálise (1935); As culturas negras no Novo 
Mundo (1937); A aculturação negra no Brasil (1942); Guerra e relações de raça (1943); e, postumamente, foram publicadas $A$ mestiçagem no Brasil em Paris (1952)1 e O negro na civilização brasileira (1956).

Essas obras tiveram um papel fundamental no embate com as teorias racistas, consolidadas no século XIX, a partir dos estudos do Conde de Gabineu (1816-82), que defendia a tese da superioridade da raça ariana e, depois, com o Darwinismo Social, a tese da sobrevivência do mais forte, juntamente com a do Evolucionismo Social, que acreditava na evolução das sociedades de um estado primitivo para o civilizado. Todas essas teorias particularizavam o negro como geneticamente inferior. No Brasil, vários intelectuais do final do século XIX e início do XX foram adeptos dessas teorias, entre eles, Nina Rodrigues, Euclides da Cunha e Sílvio Romero.

Décadas depois dos estudos desses intelectuais brasileiros, Arthur Ramos elaborou uma leitura culturalista da etnia negra, apropriando-se do conceito de base psicanalítica, em sua fase inicial de pesquisa, e, depois, da Antropologia. Em seus escritos, defendeu a tese de que o negro não deveria ser concebido como uma raça degenerada, como afirmavam as ciências racistas. Mais precisamente na obra $A$ criança problema, o autor alertou para que não se interpretassem problemas sociais e culturais como de origem genética ou biológica. Assim, ele buscou, naquela geração de intelectuais, esboçar uma reflexão sobre a cultura negra a fim de solucionar os problemas sociais, antes atribuídos às "raças", e deslocá-los para o âmbito social.

Desse modo, nosso objetivo neste estudo é tentar captar o entendimento de Arthur Ramos em relação à cultura negra e seu valor na constituição e formação do negro. Em outras palavras, qual

1 A obra apenas é publicada no Brasil em 2004. 
o lugar da cultura negra nos escritos de Arthur Ramos? Qual sua leitura sobre a cultura afro-brasileira e o valor atribuído à educação? Qual o limite de suas abordagens considerando sua época?

\section{As teorias racistas e a questão da cultura negra no Brasil}

Desde meados do século XIX, o pensamento intelectual brasileiro passou a ser influenciado pelas teorias racistas vindas da Europa, como o Positivismo, o Evolucionismo e o Darwinismo Social. Todas tendo como questão comum a legitimação das desigualdades sociais, as quais apresentavam o branco europeu como etnia superior. Menezes (2002, p. 98) destaca que: "A nação brasileira foi pensada em termos de raça, antes mesmo de ser pensada em termos de cultura ou economia".

Com a chegada da República, houve a preocupação do governo e de intelectuais da época em conter a população negra e mestiça então livre, concebidas como inferiores, imorais, indolentes e degeneradas. Para eles, uma população composta desses tipos raciais teria como consequência a não evolução da nação brasileira para o estágio de sociedade civilizada.

$\mathrm{Na}$ mesma perspectiva de Menezes, Kabengele Munanga (2003, p. 54) adverte que "A pluralidade racial nascida do progresso colonial representava, na cabeça dessa elite, uma ameaça e um grande obstáculo no caminho da construção de uma nação que se pensava branca". Um dos muitos intelectuais do final do século XIX e início do XX que comungava dessa opinião era Euclides da Cunha (1902). Para ele,

[...] a mistura de raças mui diversas é, na maioria dos casos, prejudicial. Ante as conclusões do evolucionismo, ainda quando reaja sobre o produto o influxo de uma raça superior, 
despontam vivíssimos estigmas da inferior. A mestiçagem extremada é um retrocesso (p. 141).

Outro intelectual brasileiro que compartilhava dessa ideia era o médico maranhense Nina Rodrigues, sendo este o principal representante dos estudos sobre o negro de sua época. Influenciado por cientistas estrangeiros, defendeu a tese de que os negros e mestiços eram seres humanos inferiores e degenerados tanto biologicamente quanto culturalmente. Mesmo concebendo o negro como ser rebaixado, Nina Rodrigues não deixou de ressaltar a contribuição daquela etnia para a sociedade brasileira. Em sua clássica obra Os africanos no Brasil (1933)², argumenta que

A raça negra no Brasil, por maiores que tenham sido os seus incontestes serviços à nossa civilização, por mais justificadas que sejam as simpatias de que a cercou o revoltante abuso da escravidão, por maiores que se revelem os generosos exageros dos seus turiferários, há de constituir sempre um dos fatores de nossa inferioridade como povo (Rodrigues, 2010, pp. 14-5).

Para Nina Rodrigues, essa “inferioridade” da população brasileira, composta por homens de cor, apenas seria combatida com a vinda da imigração europeia para o Brasil, que teria como consequência o branqueamento biológico da população. Nas primeiras décadas do século XX, chegou ao país o discurso eugênico que pretendia um "melhoramento da raça" negra por meio do cruzamento com a etnia considerada superior, ou seja, a branca, época

2 Esta obra foi lançada postumamente. Nina Rodrigues não chegou a concluí-la, segundo Souza (2013), a obra foi acabada graças aos trabalhos dos membros da "escola Nina Rodrigues" que reuniram os cadernos e documentos. 
em que o Brasil pretendia alcançar o modelo de modernidade já presente nos países europeus e nos Estados Unidos.

\section{A cultura negra em Arthur Ramos}

Como assinalado, o antropólogo alagoano Arthur Ramos foi um dos primeiros estudiosos brasileiros que tentou inverter a condição do negro como ser biologicamente inferior. Mesmo contrário à teoria da inferioridade biológica, tese defendida por Nina Rodrigues, Arthur Ramos teve o médico maranhense como mestre em relação aos estudos sobre o negro. Em suas obras, Ramos tece elogios aos estudos do pensador maranhense por ele ser o pioneiro nos estudos da questão negra no Brasil, como ele salienta no prefácio da obra O folclore negro do Brasil (2007):

No decorrer desse largo período de 'scotoma' para o problema da raça negra no Brasil, apenas se salvou a obra de Nina Rodrigues. Eu não me canso, em meus estudos atuais sobre o negro brasileiro, de chamar a atenção para os trabalhos de Nina Rodrigues, na Bahia, ponto de partida indispensável ao prosseguimento de um estudo sistematizado e sério sobre a questão (p. 4). ${ }^{3}$

Para o antropólogo alagoano, as impressões negativas atribuídas ao negro por Nina Rodrigues eram motivadas pelos estudos limitados de sua época, contaminados pelas teorias racistas europeias que justificavam a inferioridade do negro. No seu primeiro estudo sobre o negro, Os horizontes místicos do negro na Babia (1932), o autor ressalta que a visão constituída pelo médico maranhense deu-se porque "na sua época, não contou Nina Rodrigues

3 A primeira edição do livro O Folclore Negro no Brasil foi publicada em 1935. 
com esses métodos novos da psychologia comparada que os estudos de Lévy-Bruhi vão tornando clássicos” (Ramos, 1932, p. 40).

Os escritos de Arthur Ramos estão situados numa época na qual havia um tímido ensaio sobre o valor do negro e de sua cultura. Assim como ele, Gilberto Freyre se opôs ao determinismo biológico das teorias racistas. Freyre insistiu em dizer que "a miscigenação racial, característica do Brasil, era um fato positivo, talvez a mais importante e melhor herança herdada da colonização portuguesa" (Oliveira, 2002, p. 41). Entretanto, Menezes (2002) lembra que, apesar dos dois intelectuais repudiarem a noção de inferioridade racial, ambos introduziam noções de psicologia e eugenia, o que acabava por tornar suas frases carregadas das conotações biológicas das quais pretendiam se desfazer.

$\mathrm{Na}$ década de 1930, com o declínio das teorias racistas, tão aceitas pelos intelectuais da segunda metade do século XIX e início do XX, surgiu no panorama intelectual brasileiro o interesse pelo tema das relações raciais, inseridas agora numa discussão de valorização dos negros pela produção científica, tornando-se objeto de estudo dos "antropólogos culturalistas" europeus e norteamericanos, como Roger Bastide (1898-1974). Estes passaram a influenciar intelectuais brasileiros, como Arthur Ramos, embora houvesse um grande grupo de intelectuais, como Oliveira Viana, que ainda permaneceria com a vertente racista em seus estudos.

A produção intelectual relacionada aos negros não despertava apenas o interesse no meio acadêmico, mas também do Estado brasileiro. A política varguista, conforme Tamano (2013, p. 153), "[...] buscava mesclar a diversidade cultural existente no país a fim de encontrar uma espécie de “'essência' brasileira”". Com esse ideal, o negro passava a ser visto pela sociedade como parte integrante dela. É provável que os estudos culturalistas do intelectual alagoano tenham tido boa receptividade dentro do governo Vargas, em razão de ter esse apelo regenerador da mente e do corpo dos indi- 
víduos de etnia negra, princípios esses que estavam alinhados aos governos nazifacistas europeus.

A produção de Arthur Ramos, que é extensa, foi sendo acomodada também à política do Estado brasileiro quando ele participou da Diretoria do Serviço de Ortofrenia (que defendia a correção de um estado mental) e Higiene Mental do Distrito Federal (atual Estado do Rio de Janeiro), em conjunto com Anísio Teixeira. A sua colaboração com estudos sobre os aspectos psicossociais da população o levou a ter destaque no cenário educacional do período.

Seus estudos foram beneficiados pelo novo cenário intelectual brasileiro dos anos 1930. Portanto, a questão negra tinha como referência a Psicanálise de Freud e os estudos do sociólogo e filosofo francês Lévy-Bruhl. Este último defendia a tese de que as sociedades classificadas como "atrasadas", a exemplo da brasileira, tinham a mentalidade pré-lógica.

Em O negro Brasileiro, esclarece que, "estudando, neste ensaio, 'as representações coletivas' das classes atrasadas da população brasileira, no setor religioso, não endosso absolutamente, como várias vezes tenho repetido, os postulados de inferioridade do negro e da sua capacidade de civilização" (Ramos, 1934, p. 30). Em continuação, o alagoano afirma que a questão não era racial, mas psicológica, pois a etnia negra cultivava um pensamento mágico e pré-lógico:

Essas representações coletivas existem em qualquer tipo social atrasado em cultura. É uma consequência do pensamento mágico e pré-lógico, independente da questão antropológico-racial, porque podem surgir em outras condições e em qualquer grupo étnico. [...] Esses conceitos de 'primitivo', de ‘arcaico' são puramente psicológicos e nada têm que ver com a questão de inferioridade racial (p. 32). 
Embora defendesse a igualdade entre as raças do ponto de vista biológico, o antropólogo não deixou de ressaltar que existiam culturas "adiantadas" e "atrasadas". Nesse sentido, Ramos conseguiu romper com uma leitura míope da geração de Nina Rodrigues e caiu numa outra própria de sua época. Como salienta Souza (2013), "o autor retira o problema do negro dos campos racial e médico-biológico, levando-o para o campo cultural”. No entanto, é preciso dizer que Arthur Ramos não aplicou a noção de atraso cultural somente ao negro, mas também a todos os grupos étnicos que se encontravam sem acesso à formação letrada, e que, dessa maneira, não haviam desenvolvido o campo racional tal como supostamente acontecia com aqueles que frequentavam os espaços escolares e acadêmicos.

É necessário dizer que essa forma de conceber a cultura negra esteve circunscrita pelos limites do pensamento de sua época. Os intelectuais da geração de Ramos cultivavam uma leitura preconceituosa do negro. E dificilmente eles escapariam dessa linha de pensamento naquele período. Embora tivesse conseguido ultrapassar o preconceito racial da geração de Nina Rodrigues, a geração do antropólogo alagoano tinha uma confiança quase cega no poder da razão e das letras na formação de sujeitos capazes de vencer os vícios e hábitos e serem moralmente justos. Nesse sentido, a educação seria o meio para corrigir os comportamentos considerados inadequados para uma nação que se pretendia moderna, ou seja, a educação era vista, percebida ou apresentada como a solução para os problemas sociais. Dávila (2006, p. 58) lembra que, "embora o Brasil tivesse chegado ao século XX sob o peso do racismo científico e o estigma que ele aplicava à nação racialmente mista, essa corrente logo deu lugar ao enfoque ambiental e cultural da degeneração".

A cultura e a religiosidade negra, assim como daqueles grupos socialmente rebaixados, para Arthur Ramos, mantinha-se numa mentalidade pré-lógica e primitiva, como já salientamos. E essa 
mentalidade representaria um prejuízo para a nação brasileira, que deveria ser sanado pela higienização e particularizado pela educação.

Já temos mostrado, em mais de um trabalho, os perigos dessa mentalidade pre-lógica, no Brasil, denunciando certos fenômenos de feitiçaria, baixo-espiritismo, demonopatias e outros, e sua nefasta influência na formação da personalidade. Dada a sua extensão, apenas abordamos aqui de leve o tema, que está a exigir um exame sério dos nossos administradores de saúde. O pauperismo, as condições deficitárias de saúde e higiene, a sub-alimentação, a incultura... geram inferioridades de toda a sorte, orgânicas e mentais (Ramos, 1939, pp. 38-39).

Como podemos constatar, havia um discurso médico para justificar a correção das condições materiais e mentais de uma população, supostamente desvirtuada do ponto de vista da conduta humana daquela época. Nesse período, a medicina e a educação caminharam juntas para pôr fim aos comportamentos considerados socialmente desajustados.

Os estudos de Garcia (2010) ressaltam que essa concepção de Arthur Ramos não o tornava racista, e quem utilizou esse argumento para classificá-lo como tal cometeu um julgamento injusto.

Sobre a utilização do conceito de mentalidade primitiva que serviu para qualificar Ramos como racista, como foi o caso da interpretação de Dávila (2006), fazia-se necessário relativizar um pouco a questão, a fim de não cair em um julgamento injusto sobre a obra e o pensamento do médico alagoano. Como já havia afirmado o autor, o conceito de Lévy-Bruhl não se aplicava a um grupo étnico específico e nem tinha uma conotação étnicoracial na medida em que 
poderia ser aplicado às crianças, alienados, comunidades primitivas e até mesmo em indivíduo vivendo em sociedade urbana e industrializada. (Garcia, 2010, p. 92).

Considerando os ideais da época, não seria possível, então, articular ou atribuir um valor positivo à cultura negra nos anos 30 e 40 do século XX. Pois, os limites do ponto de vista intelectual daquela geração ainda não conseguiam ultrapassar a barreira de uma mentalidade na qual o modelo de homem, de cultura e de sociedade era o europeu, com seu pensamento etnocêntrico.

\section{Arthur Ramos e a correção de condutas pela educação}

Em meados do século XX, o sistema educacional brasileiro era para poucos, afirmando em sua organização ideologias europeias, e continuava com os discursos de intelectuais de que os males sociais seriam corrigidos pela educação. Nesse contexto, as ideias da Escola Nova chegaram ao Brasil com o objetivo de mudar o cenário da educação nacional, sobretudo aquela destinada às escolas primárias, cujo principal foco passou a ser a criança, e um ensino que conduzisse à autonomia do educando. Os ideais da Escola Nova no Brasil tinham como seu principal representante Anísio Teixeira. Sobre esse intelectual salienta Sircilli (2005):

Teixeira era marcadamente influenciado pelo filósofo-educador norte-americano John Dewey, para quem a educação deveria manter o equilíbrio entre o homem e suas particularidades psicológicas, de um lado, e as exigências da sociedade em que vivia, de outro (Sircilli, 2005, p. 189).

Arthur Ramos não escapou a essas concepções e foi influenciado pelas ideais da Escola Nova. Garcia (2010) chama atenção 
para o fato de que, para o autor alagoano, embora o objeto pedagógico da Escola Nova fosse centrado na criança, seu objetivo mais importante era para como a sociedade, uma vez que ambicionava produzir indivíduos capazes de atuar nas diferentes necessidades da vida em constante transformação. Garcia (2010, p. 114) ressalta ainda que "para que isso ocorresse era fundamental que a pedagogia baseada na própria experiência que acumulou ao longo dos tempos auxiliasse os indivíduos a encontrarem seu caminho".

Em 1933, Arthur Ramos foi convidado por Anísio Teixeira para dirigir o Serviço de Ortofrenia e Higiene Mental do Instituto de Pesquisas Educacionais (IPE), do Rio de Janeiro. Ao dirigir o referido Instituto, Arthur Ramos também aproveitou para realizar pesquisas para seus futuros trabalhos na área educacional, como as obras Saúde do espirito (1939) e A criança problema (1939), as quais davam orientações educacionais para pais e educadores. Dávila (2003) lembra que o Rio de Janeiro se tornou, nesse período, um imenso laboratório para as ideias eugênicas.

Para atender ao projeto de formar uma "raça" brasileira, cientistas e médicos começaram a fundar, nas décadas de 1920, sociedades eugênicas no Brasil. Entre os adeptos estavam intelectuais e educadores brasileiros, como Fernando de Azevedo, Edgar Roquete Pinto e Afrânio Peixoto. Para os intelectuais, a escola seria o meio de pôr em prática ideias eugênicas: "O consenso entre os formuladores de políticas era que as escolas eram as linhas de frente da batalha contra a 'degeneração'. Os educadores transformaram as escolas em laboratórios-lugares onde ideias sobre a raça e nação eram testadas e aplicadas sobre as crianças”. (Dávila, 2006, pp. 556). O autor classifica Arthur Ramos como integrante desse bloco intelectual eugênico. Na obra Saúde do espírito, Ramos se opôs a uma eugenia racial, mas não cultural:

Todo um capítulo da chamada 'higiene racial' tem de ser revisto aqui. No Brasil, especialmente, muito se clamou, 
era voz de alguns teóricos estrangeiros (e alguns nacionais!), que somos um 'povo inferior provindos de 'raças inferiores', que aqui cruzaram as suas 'hereditariedades desharmonicas”. O negro foi a nossa perdição! - Clamaram alguns. Devemos voltar ao ariano! Só pelo cruzamento com o branco, voltaremos ao ariano! - Gritaram outros.

Esses falsos cientistas acharam ainda que a mestiçagem era um fator de 'degenerescência'. Uma das causas do nosso atraso estava no mestiço desharmônico, incapaz, inferiorizado.

O que se atribuía a um mal de raça verificou-se que era um mal de condições higiênicas deficitárias: sub-alimentação, pauperismo, doenças, alcoolismo... carregando no seu bojo toda a sorte de 'inferioridade'.

Não precisamos de cruzamentos eugênicos. Precisamos é melhorar o que temos. Os estudos contemporâneos de um grupo de pesquisadores brasileiros, [...] veem clamando que a pretensa inferioridade do mestiço brasileiro melhorará e desaparecerá quando cessarem os déficits ambientais de toda a natureza (Ramos, 1939, pp. 38-9).

Para Garcia (2006), o médico alagoano não fazia parte da ciência eugênica, pois apenas queria uma melhor condição de vida para o negro. No entanto, o próprio Arthur Ramos classifica a Higiene Mental como um modelo preventivo e de correção de conduta. Pinheiro (2015) destaca que no livreto Família e escola, escrito por Ramos em 1934, evidenciava que higiene mental estava muito mais ligada ao trabalho preventivo que o de correção. Mas, em $O$ negro brasileiro, Ramos deixou claro o poder da educação para corrigir as práticas culturais inferiores.

Assim, para a obra da educação e da cultura, é preciso conhecer essas modalidades do pensamento 'primitivo' para 
corrigi-lo, elevando-o a etapas mais adiantadas, o que só será conseguido por uma revolução educacional que aja em profundidade, uma revolução 'vertical' e 'intersticial' que desça aos degraus remotos do inconsciente coletivo e solte as amarras pré-lógicas a que se acha acorrentado (Ramos, 1940, p. 31).

Ainda em $O$ negro brasileiro, Ramos também evidencia seu conceito de inferioridade atribuído à cultura negra. Segundo ele, se não estudasse as mentalidades da classe "atrasada", a obra da educação não poderia ser realizada, bem como prejudicaria o trabalho dos professores e higienistas.

Transportando-me para o Rio de Janeiro, fui honrado com o convite de Anisio Teixeira para instalar um Serviço de Higiene Mental nas Escolas do Distrito Federal. Entre outros afazeres deste Serviço, pus-me a estudar a população dos morros do Rio de Janeiro e por ai, progressivamente, penetrei no reconcílio das macumbas e dos centros de feitiçaria. Deste modo, o presente trabalho não deixa de ter um largo alcance higiênico e educacional. Evidentemente nada teremos realizado em matéria de educação se, preliminarmente, não procurarmos conhecer a própria estrutura dinâmico-emocional da nossa vida coletiva. E todo o trabalho resultará improfícuo se não desenredarmos todas as tramas inconscientes do logro e da superstição, impedindo que uma resistência surda e insidiosa vá desmanchar posteriormente todo o árduo trabalho dos educadores e dos higienistas (Ramos, 1940, p. 30).

Observamos nas falas apresentadas que o preconceito contra o negro ou a correção moral e comportamental ainda estavam presentes nesse intelectual, que se posicionou como crítico das teorias racistas do século XIX e ainda difundidas nas primeiras décadas 
do século XX. Arthur Ramos, como os outros intelectuais, considerava a educação como um processo de branqueamento do negro, do ponto de vista da cultura. Nesse sentido, o antropólogo apresentou as mesmas opiniões defendidas por intelectuais do século XIX, ainda que se posicionasse contrário à inferioridade biológica do negro e do mestiço (Santos, 2008). Pinheiro (2015) salienta que, embora o antropólogo não defendesse a inferioridade do negro, ele esbarrou "numa visão problemática sobre outro tipo de hierarquização, o das culturas". Supondo sair em defesa das "culturas atrasadas", defende a capacidade delas de "evoluir", de se civilizar, superando seus supostos atrasos, "milagre" somente possível graças à educação" e seu poder correcional.

É necessário ressaltar que o conjunto de intelectuais dos anos de 1920 a 1940 não escapou de uma leitura evolucionista da humanidade impulsionada pelo desenvolvimento racional e moral da escola.

\section{Considerações finais}

É possível concluir que os estudos de Arthur Ramos sobre as relações ente a cultura negra e a educação, levando em consideração os limites de sua época, contribuíram para revogar a tese da inferioridade biológica do negro, mas, ao mesmo tempo, permaneceu a tese da inferioridade cultural das populações que não tinham acesso ao saber letrado, como se os argumentos relacionados à cultura não fossem um aspecto de rebaixamento de um povo. Para Ramos, esses grupos considerados atrasados culturalmente apenas evoluiriam por meio da educação escolar, que era considerada pelos intelectuais como a chave para se alcançar o progresso e a civilização do país.

Com essa concepção, Arthur Ramos acabou compartilhando das mesmas leituras de seus pares em relação ao povo brasileiro e contribuindo, assim, para que a população negra ainda perma- 
necesse à margem da sociedade brasileira. Com esse propósito, Ramos compartilhava da intenção política do Estado brasileiro Varguista de formar uma nação moderna e consequentemente civilizada, moldada ao conceito cultural e moral da Europa.

Do mesmo modo que no projeto político nacional, esses homens considerados de letras, como Ramos, compreendiam que a educação escolar era a chave para atenuar os comportamentos desviantes, e, sobretudo, corrigir a inferioridade cultural dos grupos supostamente "atrasados", e, assim, corrigir cotidianamente pensamentos e hábitos, educar o corpo, os sentidos e os gestos, para atender uma sociedade que demandava novos sujeitos, agentes da nação.

\section{Referências}

CUNHA. Euclides. Os sertóes (Campanha de Canudos). São Paulo: Martin Claret, 2006. (Coleção Obra Prima de Cada Autor).

DÁVILA, Jerry. Diploma de brancura: politica social e racista no Brasil (1917-1945). São Paulo: UNESP, 2006.

GARCIA, Ronaldo Aurélio Gimenes. A trajetória intelectual de Arthur Ramos: higiene mental e criança problema (1939-1949) (dissertação). Universidade Federal de São Carlos, 2010.

GASPAR, Lúcia. Arthur Ramos. Fundação Joaquim Nabuco, Recife, 2010. Disponível em: http://basilio.fundaj.gov.br/pesquisaescolar. Acesso em: 17 jun. 2016

MENEZES, Maria Odete. A psicanálise na Babia (1926-1937): os estudos de Arthur Ramos sobre a loucura, educação infantil e cultura (dissertação). Universidade Federal da Bahia e Universidade Estadual de Feira de Santana, 2002. 
MUNANGA, Kabengele. Rediscutindo a mestiçagem no Brasil: identidade nacional versus identidade negra. 2 ed. Autêntica, 2004.

OLIVEIRA, Laiana Lannes de. A frente negra brasileira: politica e questão racial nos anos 1930 (dissertação). Universidade do Estado do Rio de Janeiro, 2002.

PINHEIRO, José Gledison Rocha. O diário de Dalila: poética, testemunho e tragédia na formação escolanovista do indivíduo moderno (1933-1934) (tese). Universidade Federal da Paraíba, 2015.

RAMOS, Arthur. Os horizontes misticos do negro na Babia. s/e, 1932.

. As culturas negras no Novo Mundo. Rio de Janeiro: Civilização Brasileira, 1937

. Saúde do espirito: higiene mental. Rio de Janeiro: Departamento Nacional de Saúde, 1939.

. O negro brasileiro. 2 ed. São Paulo: Cia. Editora Nacional, 1940.

. Aculturação negra no Brasil. São Paulo: Cia. da Editora Nacional, 1942.

. Guerra e relações de raça. Rio de Janeiro: Gráfica Perfecta, 1943.

. O negro na civilização brasileira. Rio de Janeiro: Casa do Estudante do Brasil, 1956.

. A mestiçagem no Brasil. Maceió: Edufal, 2004. . Folclore negro no Brasil. São Paulo: Martins Fontes, 2007. 
RODRIGUES, Nina. Os africanos no Brasil. Rio de janeiro: Biblioteca Virtual de Ciências/Centro Edelstein de Pesquisas Sociais: 2010. Disponível em: http://www.ufgd.edu.br/reitoria/neab/downloads/os-africanos-no-brasil. Acesso em: 9 out. 2011.

SANTOS, Monica Luise. A educação de meninos negros na Escola Central em Maceió (1881-1893) (Trabalho de Conclusão de Curso - Pedagogia). Universidade Federal de Alagoas, 2008.

SIRCILLI. Fabíola. "Arthur Ramos e Anísio Teixeira na década de 1930”. In: Paidéia, 2005 Disponível em: http://www.scielo. br/pdf/paideia/v15n31/06.pdf. Acesso em: 26 jun. 2013.

SOUZA, Fabíola Amaral Tomé de. A presença do negro no pensamento social brasileiro. 2013. Disponível em: http://www.educacaopublica.rj.gov.br/biblioteca/historia/0110.html. Acesso em: 22 jun. 2013.

TAMANO, Luana Tieko. Arthur Ramos e a mestiçagem no Brasil. Maceió: Edufal, 2013. 


\title{
A INFÂNCIA NA REVISTA DE ENSINO (1927-I93I) EM ALAGOAS
}

\section{Um contraponto com Walter Benjamin I}

\author{
Regina Brito Mota dos Santos
}

\section{Introdução}

Parcela significativa das representações de infância que emergem da Revista de Ensino alagoana partilha de uma visão ativa, progressiva e, ao mesmo tempo, isolada e individual desse tempo de vida da criança. Os adjetivos atribuídos à infância como um tempo de imitação, fantasia e vivacidade revelam uma maneira de enxergar a criança como um ser atuante na construção de um novo tempo e modelável aos objetivos culturais impostos pela modernidade, que, no Brasil, foram fundamentados teoricamente por John Dewey nos debates educacionais a respeito da Escola Nova e reafirmados pela mentalidade republicana na definição das políticas públicas direcionadas à educação.

De acordo com o estudo feito por Iane Martins (2014), a Revista de Ensino foi criada como um órgão oficial da Diretoria Geral da Instrução Pública de Alagoas, em 1925, tornando-se posteriormente veículo de divulgação da Sociedade Alagoana de Educação,

1 O estudo é parte dos resultados da pesquisa da monografia de conclusão do curso de Pedagogia, já finalizada, da Universidade Federal de Alagoas (UFAL). 
a partir de 1930. O periódico passou a ser um meio de fornecer informação aos professores e divulgar os novos processos de ensino, já que eram publicados planos de aula, ensaios de professores da Escola Normal de Maceió, do Liceu Alagoano, dos Grupos Escolares da capital e trabalhos de autores do cenário nacional e internacional com temas relacionados à Escola Nova.

É importante ressaltar que as discussões sobre a educação da criança no periódico não advêm apenas de professores alagoanos envolvidos no movimento de renovação educacional, mas também partem de referências que estavam nacional e internacionalmente articuladas. Como ressalta Martins (2014), muitas as discussões travadas aqui foram exportadas de outros estados do Brasil, como o Rio de Janeiro, o que demonstra a pretensão de espalhar o pensamento pedagógico europeu e norte-americano para solucionar o problema da educação no Brasil. José Ribeiro Escobar ${ }^{2}$ é exemplar para evidenciar que a defesa de uma educação ativa é uma ideia exportada de São Paulo, que foi apropriada pelos intelectuais alagoanos e de outros estados brasileiros, tendo em vista que o professor publicou em outras revistas homônimas.

Para atender ao objetivo de compreender e apresentar as primeiras aproximações dos enunciados sobre a infância, ajudaram-nos os textos: Primeiras licções de Arithmetica (1927), de Charles Laisant; Disciplina da liberdade (1928), de Maria Rosalia Ambrozzio; O lar e a escola (1927), de Francisco Moreno Brandão; $A$ curiosidade das creanças (1927), de Maria Amália Vaz de Carvalho; Ensino de História pátria (1927), de Craveiro Costa; A escola

2 De acordo com informações extraídas da Revista de Ensino (1927), José Ribeiro Escobar foi lente de didática da Escola Normal de São Paulo e participou ativamente das cruzadas pedagógicas em Alagoas e Pernambuco, onde se pretendia divulgar os novos processos de ensino. A sua obra Ensino de fracções foi recomendada como indispensável aos professores primários de Alagoas. 
activa (1930), de Mercedes Dantas; e $O$ aprendizado activo (1930), de José Ribeiro Escobar. A discussão sobre a infância, a experiência infantil e a capacidade de compreensão da criança desenhada no periódico se apresenta ao passo que se discute sobre a aprendizagem, o modo correto de ensinar história e sobre a discussão referente a um tipo de família como uma entidade que cuida, educa e protege a criança, considerada como um ser frágil e sujeito do futuro. Com esse fim, tudo que circunda a vida infantil, inclusive os brinquedos e as brincadeiras, precisam ser voltados para um fim utilitário: a incorporação de conhecimentos necessários ao trabalho que a criança realizará no futuro.

É importante ressaltar a pluralidade de vozes que compuseram a Revista, que, apesar da predominância do escolanovismo de John Dewey, também contou com o discurso da Igreja de centralidade da família na educação, o que significava a preservação de valores morais religiosos na educação da criança. De acordo com Saviani (2005), passou a ser divulgada nos meios católicos uma espécie de "Escola Nova católica", que mantinha preocupações explicitamente religiosas e, ao mesmo tempo, se inseria no movimento europeu da Escola Nova. A ideia era, portanto, "[...] buscar um novo método pedagógico que atendesse igualmente às exigências postas pelos objetivos da educação católica e pela renovação pedagógica" (Saviani, 2005, p. 16) ${ }^{3}$ e que exerceu grande influência no pensamento pedagógico brasileiro. Por outro lado, o movimento renovador se utilizou desse mesmo discurso para fazer chegar, em todas as esferas sociais, inclusive na família, os princípios de formação democrática, quais sejam, disciplina, obediência e amor ao trabalho, compondo assim uma espécie de disciplina social.

3 O referido texto foi elaborado para o "Projeto 20 anos do Histedbr", realizado em Campinas, em 25 de agosto de 2005, no âmbito do projeto de pesquisa "O espaço acadêmico da pedagogia no Brasil". 
Esse projeto democrático de sociedade alimentava a crença na educação de uma criança capaz de regenerar a sociedade no futuro. A esse respeito, é importante trazer o contraponto de Valdemarin (2006), ao analisar que, para o próprio Dewey, o pré-requisito para a efetivação das propostas escolanovistas era a existência de uma sociedade democrática, não apenas como regime político, mas também como forma de vida compartilhada, na qual os problemas fossem comuns aos grupos sociais. No entanto, a sociedade para a qual a criança brasileira estava sendo formada compreendia a republicana, em que a igualdade social era ainda um projeto muito longe de ser alcançado.

Partilhando dessas preocupações, este texto está dividido em três partes. A primeira, "A educação da criança no contexto e renovação pedagógica”, apresenta um breve apanhado sobre o contexto histórico dos anos 1920 e 1930 e o lugar da criança no contexto nacional de renovação pedagógica. A esse respeito, as obras $U m$ desastre (2007), de Graciliano Ramos, e a crônica O padre Cornélio (1921), do professor alagoano Luis Lavenére, servem-nos como importantes testemunhos históricos sobre a educação alagoana, além das produções de pesquisadores do campo da História da Educação, como Elza Silva (2009), Saviani (2006) e Veiga (2007). A segunda parte, "Discursos sobre a natureza infantil e a infância 'iluminada”, apresenta a análise dos artigos selecionados, que tratam da infância no periódico, seguida de uma discussão sobre "A educação da infância como preparação para o mundo do trabalho", discutida na terceira parte. Em ambas, procurou-se identificar as influências do pensamento escolanovista de John Dewey nos debates sobre a infância e a educação da criança em Alagoas e fazer o confronto com as ideias de Walter Benjamin a respeito da experiência e formação infantil. Por fim, são apresentadas as considerações finais da pesquisa. 


\section{A educação da criança no contexto de renovação pedagógica}

Notadamente nos anos de 1930, estão concentradas mudanças substanciais de reformas na educação, entre as quais é possível citar: a criação do Ministério da Educação (MEC), que, com a reforma do ministro Francisco Campos, em 1931, regulamentou o sistema educacional em âmbito nacional; e, em 1934, a elaboração da primeira constituição que fortalecia a exigência de criação de diretrizes nacionais, com a ordenação do Plano Nacional de Educação. O objetivo era a difusão do ensino público a toda a população: "Emergia a tendência a considerar a escola como a chave para a solução dos demais problemas enfrentados pela sociedade, dando origem à ideia de escola redentora da humanidade" (Saviani, 2006, p. 22).

Naquele período, o movimento da Escola Nova no Brasil propagava a necessidade de desenvolver métodos e filosofias que contemplassem o sujeito moderno, quando também ganhavam força os estudos que tematizaram a higiene da mente e do corpo da criança, condição prévia e indispensável para uma sociedade civilizada, tal como enfatiza Veiga (2007, p. 264): “A difusão das concepções higienistas e eugênicas e sua aplicação na rotina escolar revelam uma nova concepção de infância, a criança como objeto de experimentação e especulação científica”.

Inserida no contexto de difusão da escolarização da infância alagoana, a Revista de Ensino foi a grande responsável pela representatividade dos ideais escolanovistas no Estado de Alagoas. As discussões sobre a educação pensada para a criança no periódico a tomava como perfeito "capital humano". Era exigido dos pequenos não mais a memorização de conteúdos relacionados ao passado, mas o contato com o que lhe era ensinado no presente por meio da observação e da experimentação, atividades sempre voltadas a prepará-los para o mundo do trabalho, fosse ele rural ou industrial. 
A escolarização da infância partia do princípio de que o ensino deveria ser planejado, em parte, pelos próprios alunos e parcialmente planejado, só em esqueleto, previamente pelo professor, porque as matérias deveriam estar ligadas a alguma experiência significativa da vida da criança. $\mathrm{O}$ ensino era também progressivo porque se pautava em uma busca pela ruptura com o passado imperial, situando as iniciativas republicanas no terreno da modernização e do progresso. Não bastava que a criança fosse alfabetizada, era necessário formá-la para que se tornasse o homem novo do futuro e inaugurasse uma nova sociedade.

Veiga (2007) argumenta a respeito do desprezo da elite pela educação da criança da escola pública, já que amplos setores da população brasileira continuavam excluídos do processo educacional. De acordo com a autora, isso se deu por diversos fatores: o número reduzido de grupos escolares, a falta de vagas e, principalmente, porque o ingresso nos grupos escolares dependia, muitas vezes, de favorecimentos pessoais ou injunções políticas. O fato é que, mesmo que os filhos dos pobres tivessem acesso à escola, a frequência era irregular e a evasão significativa, até pela necessidade de inserção precoce de crianças oriundas das camadas mais pobres no mercado de trabalho formal ou informal. Martins (2014) reforça ainda que, em Alagoas, o Estado não dispunha de recursos financeiros suficientes para suprir os gastos com a instrução pública, apesar da boa vontade demonstrada pelos adeptos da renovação pedagógica.

A esse respeito, a crônica de Lavenére (1921), quando apresenta a trajetória de formação do menino Cornélio, contribuiu com alguns vestígios sobre a educação em Alagoas, nas primeiras décadas do século XX, especialmente sobre a situação caótica das escolas públicas, a educação domiciliar e a formação moral em colégios católicos, em funcionamento em plena República. Na ocasião do sexto aniversário de Cornélio, em conversa sobre o futuro escolar do menino, a ideia de colocá-lo em uma escola pública logo é 
refutada pelo pai: "Ah! Isso não! Uma escola gratuita para gente pobre! Não fica bem a um funcionario de cathegoria ter os filhos numa escola feita exclusivamente para quem não pode pagar professores particulares..." (Lavenére, 1921, p. 112).

Em seu estudo sobre as experiências em educação infantil em Alagoas, Elza Silva (2009) demonstrou que as crianças pobres não tinham acesso ao direito de aprender a ler antes dos sete anos de idade, o que só viria a acontecer quando ou se pudessem entrar numa escola pública elementar, sempre condicionada à existência de vagas. Como consequência, a escolarização das crianças alagoanas esteve quase sempre sob a responsabilidade exclusiva das famílias.

Como “a escola pública não servia para nada”, Cornélio foi, no princípio, educado em casa por uma mestra que sofria constante fiscalização dos pais, pois tinha sempre que ouvir as recomendações da mãe do garoto, Dona Zefinha: "Não deixe de dar a licção disto, ou licção daquillo... Não quero que este menino esteja perdendo tempo... puxe por ele" (Silva, 2009, p. 115). O menino tinha que repetir todas as lições da mestra, mas, como diz o narrador da crônica "raramente as crianças reproduzem com exatidão o que ouviram”. Quando aluno do Colégio Marista de Maceió, as atividades escolares de Cornélio incluíam a reza de terços, orações, confissões, missas e comunhões.

Com efeito, em Alagoas, a escolarização da infância se manteve, durante muito tempo, sob a responsabilidade da Igreja e da família, ou, no caso dos filhos da elite, de escolas particulares, tal como nos apresenta Silva (2009). Ainda assim, os reformadores que publicaram na Revista de Ensino não consideraram as precárias condições da educação em Alagoas como um empecilho e não se intimidaram em levantar a bandeira de uma educação moderna, centrada na criança e em oposição à escola antiga. 


\section{Discursos sobre a natureza infantil e a criança "iluminada"}

- Porque, sendo a creança tão inteligente, os homens são tão tolos? - Deve ser culpa da educação [...]. O menino é a curiosidade em pessôa; a infância - uma humanidade sem experiencia, ávida de instruir-se, mas a escola mata esse estimulo, quando devêra desenvolver a torturante aspiração desses pequeninos Prometheus, emulos desse que foi a personificação das ambições mais nobres e das ansias mais sagradas do homem (Escobar, 1930, pp. 7-8, grifos nossos).

Na mitologia grega, Prometheu era um Titã, uma raça de poderosos deuses, e o seu nome significava antevisão, pois ele tinha a habilidade de predizer o futuro. Como assinala Freitas (2009), nos mitos gregos, Prometheu é quem rouba o fogo dos deuses para iluminar a humanidade, o que converge com um ideal de salvação. Disso se justifica a etimologia do nome, que remete a vidente, alguém que percebe as coisas de antemão. A referência ao mito de Prometheu, no texto escrito por José Ribeiro Escobar para a Revista de Ensino de Alagoas em 1930, descreve a criança como o ser novo que viria para romper com as tradições impostas pelos adultos e a infância, um momento da vida iluminado, capaz de salvar o país dos infortúnios que o dizimavam e, assim, dar início uma nação que se queria desenvolvida, próspera e civilizada.

Partindo de um conceito de infância como uma "humanidade sem experiência”, o autor enfatiza que a escola deve fornecer à criança o acesso às experiências das quais ela está desprovida: “é o aprendizado activo e individual, que faz funccionar integralmente o apparelho psychico e está baseado nesta regra de ouro: só se aprende a fazer, fazendo". (Escobar, 1930, p. 4). Assim, a 
criança que não é iluminada, leia-se, a criança que não conta com uma instrução que a prepare para a vida futura, que não incorpora os códigos da civilização moderna, é uma criança pobre de experiências e que não saberá se orientar no mundo moderno. "O pensamento infantil está exposto ao sophisma verbal pela falta de correspondencia entre o vocabulario abstracto que a civilisação comunica a criança e a pobreza da experiência infantil” (Escobar, p. 11).

Com tal característica, a criança foi definida pela baiana Mercedes Dantas ${ }^{4}$ (1930), partidária de uma educação moderna e fundamentada nos caudais da psicologia experimental, como "o espirito novo, radicalmente renovador que inicia a posse do mundo" (p. 4). A criança figura como um sujeito inteiramente iluminado que deve ser instruído para libertar a humanidade das "trevas". Ao avaliar a criança como um ser operante, a autora pautava que os princípios para a formação infantil moderna deveriam se aproveitar desses atributos: "a Escola Activa considera a criança um organismo activo e se basêa no principio nitidamente luminoso - o approveitamento da sua actividade espontanea, productiva e individual" (Dantas, 1930, p. 4).

A esse respeito, a filosofia de Walter Benjamin é meticulosa em nos mostrar o aspecto noturno dos dogmas iluministas para a formação infantil, porque situavam a infância em uma dimensão de homogeneidade que, ao reconhecer a criança como um sujeito ativo, pretendia torná-la o tipo ideal para a manutenção da sociedade capitalista. Sob outra perspectiva, Benjamin considera o inacabamento da infância contra a idealização da pedagogia iluminista. Para ele, a criança experimenta o mundo com a plenitude que a mantém ligada a uma experiência passada e a coloca em posição

4 De acordo com Iane Martins (2014), Mercedes Dantas foi uma jornalista, literata e professora primária baiana. É autora de dois livros de crônica, Adão e Eva e Nús, e foi professora do magistério no Distrito Federal. 
irreconciliável com a experiência descartável do mundo presente. Tal como critica Benjamin em $O$ narrador, o individualismo terminou por ser uma marca da vida moderna, característica que, na Revista, foi atribuída à infância como sendo uma peculiaridade das crianças.

Como já dito, Escobar (1930) entendia que a criança experenciava o mundo de modo isolado por julgar que o conhecimento infantil ascendia à história de seu povo e de toda a humanidade. Enquanto a infância "se caracteriza por uma grande manifestação de individualismo” (p. 10), o propósito da educação é, portanto, contribuir para que este individualismo seja acentuado: "O fim da escola é emancipar, formar Robinsons Crusoes que se bastam a si próprios" (p. 3). Sendo a infância "uma humanidade sem experiência”, a criança era, pois, um sujeito primitivo e desregrado porque não lhe estavam integrados, ainda, os padrões da nova sociedade que se pretendia instaurar.

De modo semelhante, Dantas (1930, p. 4), tendo como parâmetros os novos preceitos de orientação social, considera a criança como uma figura primitiva:

Como definir a criança diante desse principio de educação? A psychologia experimental veio provar que a criança não é um adulto incompleto ao qual se poderiam applicar os mesmos methodos indicados para o homem. Ella é apenas isto: um primitivo, um equivalente ao selvagem (grifo nosso).

$\mathrm{O}$ argumento de que a infância é uma humanidade sem experiência, e de que a criança é um primitivo, um selvagem, quando lida pelo filtro teórico de John Dewey, torna-se verídico. Isso porque, em Dewey, a experiência equivale a vivências e experimentos e, nessa lógica, "[...] é pobre e monótona porque cancela o passado, que entende como a infância ingênua da humanidade, e paralisa 
o presente, gerando uma apatia corrosiva e narcotizante" (Schlesener, 2011, p. 131). Dado que a experiência na modernidade é abreviada, segregada, incomunicável e desvinculada do nosso patrimônio cultural por estar sempre centrada em um vir-a-ser, então, é verdade que a criança é pobre de experiências, sobretudo, desse tipo, conforme acentuou Benjamin.

Ao retomarmos a crítica de Walter Benjamin sobre a situação de deslocamento da infância na modernidade, é possível identificar a linha aparentemente tênue que o separa das colocações de Escobar (1930), de que a experiência infantil é uma experiência isolada, e a de Mercedes Dantas (1930), de que a criança é "um primitivo, um equivalente ao selvagem”. "O Flanêur” (2007) é uma boa referência para acentuar, com mais precisão, a proximidade e o abismo que separa as duas visões de uma mesma tese. No referido texto, Benjamin descreve o Flanêur como um sujeito que vive a experiência da modernidade com um olhar não acostumado. Assim como o Flanêur, a criança estranha, pois a sua maneira peculiar de brincar se opõe à velocidade desenfreada da indústria, porque ela não precisa de algo mirabolante para se divertir, dos brinquedos de última geração que a mídia divulga insistentemente a fim de provocar o sentimento de necessidade. Pelo contrário, ela age "como se soubesse do caráter provocativo, insubordinado, de tal atitude, a criança deseja mais tudo aquilo que não foi destinado a ela: ela quer os farrapos, os detritos, o lixo" (Santi, 2012, p. 210). A metáfora do Flaneur é sempre um convite a esse estranhamento para com o caos e a barbárie da vida na cidade, é um conselho para nunca sairmos dessa condição de repulsão às vitórias da técnica, apesar de a modernidade não inspirar essa maneira poética de lidar com o mundo: "A rua conduz o flanêur em direção a um tempo que desapareceu" (Benjamin, 2007, p. 461).

A partir disso, é possível compreender que, apesar de a criança formar "o seu próprio mundo de coisas, um pequeno mundo inse- 
rido no grande" (Benjamin 2009, p. 58), ela não mantém uma indiferença brutal ou um isolamento insensível com relação ao resto da humanidade, mesmo porque "a criança não é nenhum Robinson Crusoé, assim também as crianças não constituem nenhuma comunidade isolada, mas antes fazem parte do povo e da classe a que pertencem" (p. 94).

Nesse sentido, a ideia desenhada na Revista de que a criança seja um primitivo e a infância uma grande manifestação de individualismo revela um posicionamento muito mais próximo de considerar a criança como uma tábula rasa do que de uma supremacia infantil que a coloca em vínculo com um passado esquecido. $\mathrm{O}$ lado arcaico e pobre de "experiências" da infância se refere a sua situação de breve desinformação das etiquetas modernas de vivência social, a ser superada pela formação "iluminada" que lhe deve chegar desde os primeiros anos de vida.

Fundamentada na concepção progressiva de desenvolvimento humano, tal como considerava John Dewey, a Revista desenhou uma infância ingênua e incapaz de conceber a seriedade do passado e do mundo adulto. Assim, todo e qualquer aprendizado precisaria respeitar o nível de desenvolvimento da criança, de modo que se mantivesse cuidado para que o conhecimento do mundo dos adultos ocorresse paulatinamente, tal como avaliou Maria Amália Vaz de Carvalho5, no texto A curiosidade das creanças:

5 Maria Amalia Vaz de Carvalho (1847-1921) foi escritora e poetisa portuguesa. Foi a primeira mulher a integrar a Academia de Ciências de Lisboa e escreveu para vários jornais em Portugal (Diário Popular, Repórter, Artes e Letras) e no Brasil (Jornal do Commércio, Rio de Janeiro), sob o pseudónimo de Maria de Sucena. Para compor a biografia de Maria Amalia Vaz de Carvalho, foram retiradas informações do portal da Literatura: http://www.portaldaliteratura. com/autores.php?autor=200. Acesso em: 18 jan. 2017. 
Ou nos havemos de consagrar á companhia de nossos filhos, á sua educação, ao desenvolvimento gradual das suas faculdades, á vigilancia solicita das suas almas e dos seus corpos, ou havemos de dar aos tenros espiritos de quem somos guias, o deploravel espetaculo das fraquezas e dos defeitos que tanto lhe desejamos fazer evitar (Carvalho, 1927, p. 75).

Com o mesmo embasamento, é possível trazer as colocações de Craveiro $\operatorname{Costa}^{6}$ (1927, p. 59) que fundamentavam a sua negação ao conhecimento do passado, na crença de que a criança vivia em um mundo paralelo às asperezas do mundo adulto e, por essa razão, os conteúdos voltados à formação infantil deveriam ter "o sabôr, tão do agrado infantil, das historias de fadas".

Imbuída nessas colocações, há subestimação da capacidade de compreensão infantil e a reafirmação do preconceito moderno de que o mundo em que a criança vive não tem nada a ver com as mazelas do mundo real. Com efeito, a psicologia do desenvolvimento, com base nas formulações de Jean Piaget (1995, p. 11), parte da premissa de que a infância é uma fase da nossa existência: "Se a criança explica em parte o adulto, podemos dizer também que cada período do desenvolvimento anuncia, em parte, os períodos seguintes".

6 Craveiro Costa foi professor e historiador alagoano, diretor dos grupos escolares Dr Diegues Junior e Pedro II, e, também esteve à frente da Sociedade Alagoana de Educação. Publicou outros artigos na Revista, como: "Historia alagoana” (1927); "Methodologia” (1927); "Educação civica” (1927); “A escola moderna" (1927); "Da historia alagoana" (1927); "Velhas opiniões" (1927); "Exames e examinadores" (1927); "Municipio do Pilar" (1930); e "Circulo de Paes e Professores" (1931). A este respeito, em sua biografia, consultar o site ABC das Alagoas. Disponível em: https://www2.senado.leg.br/bdsf/bitstream/handle/id/1104/739030_vI.pdf?sequence=7. Acesso em: 18 jan. 2017. 
De outro modo, Benjamin refuta a separação abrupta entre a infância e outras fases da vida humana e mantém uma visão das crianças não como futuros, mas como pequenos seres humanos, possibilitando a elas o conhecimento do mundo como de fato é, sem nenhum tipo de enfeite, pois, se elas deverão se tornar sujeitos completos um dia, não devemos esconder delas nada que seja relativo ao mundo dos humanos, mesmo as zonas mais tristes e sombrias: "Que os pequeninos riam de tudo, até dos reversos da vida [...]”. (Benjamin, 2009, p. 87).

Sendo assim, para que a criança se transformasse efetivamente em futuro homem novo, era necessário a ela se ajustar a essa nova ordem social e produtiva, o que seria alcançado por meio de um aprendizado ativo, gradual e voltado para as necessidades futuras. Isso quer dizer que, apesar das discussões sobre infância e educação da criança se apresentarem como indissociáveis, havia nessa relação uma nítida determinação dos papéis de servo e de senhor: era a infância que deveria estar a serviço de uma nova sociedade, e não o contrário.

\section{Discursos sobre a educação da infância como preparação para o mundo do trabalho}

O texto "Primeiras licções de artihmetica", de Charles Laisant (1841-1920)7 , publicado na Revista de Ensino em 1927, define que inclusive os jogos e as brincadeiras infantis deveriam ter um fim

O francês Charles-Ange Laisant foi um político, matemático, anarquista e educador racionalista. Publicou "As diversas numerações", na Revista, em 1927. A respeito de sua biografia, ver o texto Charles-Ange Laisant: matemático, anarquista e educador racionalista, de Rodrigo Rosa da Silva. Disponível em: https://cienciaeanarquismo.milharal.org/files/2014/01/Rodrigo-Rosa. pdf. Acesso em: 18 jan. 2017. 
utilitário, já que, na escola, a brincadeira não é lugar de distração da mente, apenas sob aparência.

Mas, todos estes differentes ensinamentos, quando destinados á infancia, devem inspirar-se invariavelmente neste principio fundamental, isto é: conservar a aparencia de brinquedo, respeitar a liberdade da creança e dar-lhe a ilusao - se acaso o é - de que é ella propria quem descobre as verdades, que lhe colocamos deante dos olhos (p. 68).

De acordo com o professor francês, se esses momentos de atividade escolar não conservarem a aparência de um simples momento de distração, o fim pedagógico falhará por completo: "É esta uma condição rigorosamente necessária para desenvolver n’ella o espirito de iniciativa, para manter a sua curiosidade natural e para evitar a fadiga, o tédio" (Laisant, 1927, p. 68). Nessa análise, a proposta do autor de que as atividades escolares devem ser conduzidas com leveza decorrente de sua aparência de brinquedo não pode ter uma importância maior do que a sua subordinação das brincadeiras infantis a uma utilidade que nada tem a ver com o que Benjamin define como a essência dessas brincadeiras: "não há dúvidas de que brincar significa sempre libertação”. (Benjamin, 2009, p. 85).

A intenção do adulto representada pela escola, claramente aprisionada pelos objetivos impostos pela cultura moderna, manifesta o desejo de transformar a criança em uma meta educacional, posteriormente convertida em benefício social, quando decide fazer dos seus momentos de brincadeira um momento utilitário. Assim, é possível que haja, na tendência em "evitar a fadiga, o tédio", uma proposta por Laisant (1927), uma repressão à situação de "ociosidade" na infância, que nada mais é do que o tempo que a criança gasta observando os detalhes despercebidos aos olhos dos adultos, que os veem como coisas inúteis. Assim como o Flanêur, 
que se mantém na contramão da cultura industrializada guiada pela mercadoria, a criança não se deixa levar pelos encantos dos objetos sofisticados: ela quer os farrapos. Do mesmo modo que "A ociosidade do flâneur é um protesto contra a divisão do trabalho" (Benjamin, 2009, p. 471), a liberdade que a criança vive em suas brincadeiras, significa sempre a sua liberação dos processos opressores da modernidade.

No texto "Disciplina da liberdade", publicado na Revista de Ensino em 1928, a professora alagoana Maria Rosalia Ambrozzio apresenta um discurso que reflete a pretensão da Escola Nova de administrar a "ociosidade" da vida na infância, para desenvolver na criança hábitos socialmente desejáveis. De acordo com a professora, a liberdade deve ter uma tendência educativa e disciplinar, para cultivar na criança os hábitos de asseio, ordem e disciplina, com o argumento de que "não é possível que a professora ceda a todos os caprichos da creança e nem que o methodo se baseie na liberdade absoluta dessas mesmas crenças" (Ambrozzio, 1928, p. 34). As suas reflexões estão baseadas no método montessoriano ${ }^{8}$ que, de acordo com Ambrózio, defende o direito espontâneo do aluno de agir, mas de um modo consciente. De acordo com essa concepção, as crianças precisam, desde os primeiros dias de aula, a respeitar limites e ter boas maneiras.

A referência à Montessori é um indício significativo do embate entre a escola nova e a escola antiga na educação alagoana. $\mathrm{O}$ discurso da Igreja Católica acerca da importância da família na

8 Maria Rosália Ambrósio foi pioneira no estado de Alagoas na defesa do método Montessori, e chegou a publicar outros artigos em que faz referência direta ao método: "Pequena palestra sobre a cultura dos sentidos" (1928) e "Em louvor a Maria Montessori” (1929). A respeito de sua biografia, consultar o site ABC das Alagoas. Disponível em: https://www2.senado.leg.br/bdsf/bitstream/handle/id/1104/739030_vI.pdf?sequence=7. Acesso em: 18 jan. 2017. 
educação da criança, proferido por Moreno Brandão, 'também se esteia nesse embate na medida em que favorece tanto às propostas liberais da Escola Nova, quando dá margem para a cultura democrática alcançar todas as esferas sociais, inclusive a família, quanto ao discurso visto como conservador da escola antiga, já que, além de buscar preservar os valores cristãos, refere-se à criança como um pequeno adulto, que não aprende nada senão pela imitação dos adultos:

$\mathrm{Si}$ attendermos a que as creanças têm $o$ instincto imitativo grandemente desenvolvido, ver-se-á como vão ellas se affeiçoando, na esphhera restricta do lar, á pratica de certas acções, e, por consequencia, obtendo conhecimentos, cuja vastidão pode-se reputar immensuravel (Brandão, 1927, p. 5).

Esse discurso revela os vestígios de uma tendência tradicional de conceber a criança como um adulto em miniatura. $\mathrm{O}$ contraponto com Benjamin nos ajuda a compreender que a criança não imita apenas pessoas, mas também objetos, animais, seres místicos e tudo o que a sua imaginação alcança. "A criança não brinca apenas de ser comerciante ou professor, mas também de moinho de vento e trem" (Benjamin, 2009, p. 117).

Fica claro que as discussões giraram em torno de uma infância que foi idealizada: a criança ativa, produtiva e iluminada correspondia a uma criança burguesa, que deveria ser educada para res-

9 Francisco Moreno Brandão (1875-1938) nasceu em Pão de Açúcar, foi lente da 1. ${ }^{a}$ cadeira de Português da Escola Normal de Maceió e publicou outros artigos na Revista, a citar, "O principado da prosa" (1929); "Gallicismos" (1930) e "Gabino Besouro" (1930). Era sócio efetivo do Instituto Histórico e Geográfico de Alagoas e membro da Academia Alagoana de Letras. Em romances como Vinho velho, A Lara e $O$ escomungado, enfocou aspectos de seu cotidiano quando viveu em São Miguel dos Campos, Maceió e Pão de Açúcar. A respeito de sua biografia, consultar o site $\mathrm{ABC}$ das Alagoas. 
ponder aos interesses da sociedade progressista que se queria implantar. Longe disso, tal como descreve Graciliano Ramos (2007), no texto Um desastre, a criança alagoana era um sujeito que subsistia: "[...] meninos ramelosos, de pernas finas, como cambitos, barrigas enormes, grávidas de lombrigas” (Ramos, 2007, p. 175). A respeito da educação dessa criança em Alagoas, como também já reafirmaram Silva (2009) e Lavenère (1921), esta se mantinha em condições precárias, impossibilitada de construir uma escola nos caudais modernos.

\section{Considerações finais}

A partir dos discursos analisados e dos argumentos construídos, é possível tecer algumas considerações sobre uma ideia, não comum, mas predominante, sobre a infância na Revista de Ensino. Os diferentes discursos sobre a criança nos permitiram desenhar uma infância que, mesmo tendo sido, teoricamente, colocada como centro, ela não era o fim. Pelo contrário, a criança era o ponto de partida para inaugurar uma nova sociedade. Dessa maneira, era a educação que determinava o ser criança como um sujeito que precisava ser iluminado e independente dos ensinamentos dos adultos, até então, mantidos por tradições.

As premissas do escolanovismo de John Dewey de que a criança deveria ser formada para exercer as atividades "fundamentais" da civilização terminou por influenciar nos discursos sobre a educação da criança alagoana, o que ficou expresso tanto na ideia de fixação dos limites da liberdade da criança proposta por Maria Ambrozzio, no fim utilitário do brinquedo, proposto por Laisant, como na formação moral apregoada por Moreno Brandão. Esses discursos deram notoriedade ao desejo de manter a criança em contato diário com determinadas regras e condutas socialmente desejáveis. Leia-se, em contato com atividades que fossem eficazes 
em desenvolver nela as habilidades que seriam úteis ao mercado e à indústria, como ordem, asseio e disciplina.

Esses julgamentos denunciavam uma indiferença dupla quanto à pobreza e às condições subumanas que também marcavam o cotidiano dessas crianças e impedia uma reforma social por meio da escola moderna, assim como, ignoravam a natureza da experiência infantil que, como alerta Benjamin, não se realiza de maneira mecânica, como pressupunham as formas de vida moderna, mas como um momento de realização plena, o que ultrapassava qualquer idealização feita pelos adultos naquele período.

De maneira minuciosa, a teoria benjaminiana sobre a formação infantil nos forneceu as bases críticas para superar os limites que a pedagogia moderna procurou impor à criança. A sua visão das brincadeiras infantis como um tempo de libertação nos permitiu perceber a infância em sua dimensão utópica, como um verdadeiro paraíso perdido na modernidade. Por fim, considero que tantas idealizações sobre a natureza infantil como modelável, assim como a proposta de uma educação infantil capaz de curar a sociedade brasileira de suas mazelas, não passaram de construções que em nada se pareciam com a realidade vivida pelas crianças brasileiras, e não correspondiam à essência infantil quanto a sua capacidade de criar, resistir e libertar-se.

\section{Referências}

AMBROZZIO, Maria Rosalia. "Disciplina da liberdade”. Revista de Ensino, ano II, n. 11, pp. 34-5, Maceió, set.-out. 1928.

BENJAMIN, Walter. "O Flâneur”. Passagens. Belo Horizonte: Editora da UNMG, 2007, pp. 461-98.

. Reflexões sobre o brinquedo, a criança e a educação. São Paulo: Ed. 34, 2009. 
BRANDÃO, Francisco Moreno. "O lar e a escola”. Revista de Ensino, ano I, n. 1, pp. 5-11, Maceió, jan.-fev. 1927.

CARVALHO, Maria Vaz. "A curiosidade das creanças". Revista de Ensino, ano I, n. 1, pp. 74-5, Maceió, jan.-fev. 1927.

COSTA, Craveiro. "Ensino de História pátria”. Revista de Ensino, ano I, n. 3, pp. 57-9, Maceió, maio-jun. 1927.

DANTAS, Mercedes. "A escola activa". Revista de Ensino, ano IV, n. 20, pp. 3-12, mar.-abr. 1930.

DEWEY, John. Experiência e educação. 2 ed. Trad. Renata Gaspar. Petrópolis: Vozes, 2011.

ESCOBAR, José Ribeiro. “O aprendizado activo”. Revista de Ensino, ano IV, n. 21, pp. 3-13, maio-ago. 1930.

FREITAS, Alexander de. "Apolo-Prometeu e Dioniso: dois perfis mitológicos do 'homem das 24 horas' de Gaston Bachelard”. Educ. Pesqui. [online], v. 32, n. 1, pp. 103-16, 2006. Disponível em: http://ref.scielo.org/n7qc8p. Acesso em: 2 dez. 2016.

LAISANT, Charles. "Primeiras licções de Arithmetica". Revista de Ensino, ano I, n. 2, pp. 67-72, mar.-abr., 1927.

LAVENÉRE, L. O padre Cornélio: scenas da vida alagoana. Jaraguá: Livraria Machado, 1921.

MARTINS, Iane Campos. “João Craveiro Costa: trajetória e vida profissional". Os escritos educacionais de João Craveiro Costa e a Escola Nova em Alagoas nas décadas de 1920 e 1930: interrelação entre ideias e práticas. (dissertação). Universidade Federal de Alagoas, 2014, pp. 22-6.

PIAGET, Jean e BARBEL, Inhelder. “O nível sensório motor”. A psicologia da criança. Rio de Janeiro: Bertrand Brasil, 1995, pp. 11-29. 
RAMOS, Graciliano. "Um desastre". Viventes das Alagoas. 19 ed. Rio de Janeiro: Record, 2007, pp. 175-8.

SANTI, Angela Medeiros. "Walter Benjamin: tempo de escola-tempo de agora: prolegômenos para uma educação para dias feriados". Educ. Soc., v. 33, n. 118, pp. 205-16, 2012. Disponível em: http://www.redalyc.org/articulo.oa?id=87322726013. Acesso em: 14 ago. 2016.

SAVIANI, Dermeval. "O legado educacional do 'longo século XX' brasileiro. In (org.). O legado educacional do século $X X$ no Brasil. 2 ed. Campinas: Autores Associados, 2006, pp. 9-54.

SCHLESENER, Anita Helena. "Educação e infância em alguns escritos de Walter Benjamin”. Paidéia, v. 21, n. 48, pp. 12935, Ribeirão Preto, 2011. Disponível em: http://ref.scielo.org/9bhj5p. Acesso em: 06 ago. 2016.

SILVA, Elza Maria da. "As raízes da educação infantil em Alagoas". A educação infantil em Alagoas: (re)construindo suas raizes. Maceió: EDUFAL, 2009, pp. 53-69.

VALDEMARIN, Vera Tereza. "Os sentidos e a experiência: professores, alunos e métodos de ensino". In SAVIANI, Dermeval (org.). O legado educacional do século XX no Brasil. 2 ed. Campinas: Autores Associados, 2006, pp.163-203.

VEIGA, Cynthia Greive. "República e educação no Brasil”. História da educação. São Paulo: Ática, 2007, pp. 237-96. 


\section{SOBRE OS AUTORES}

\section{Edgleide de Oliveira Clemente da Silva}

Doutoranda em Educação na Universidade do Estado do Rio de Janeiro-UERJ; mestre em Educação pela Universidade Federal de Alagoas-UFAL; e graduada em Pedagogia pela mesma instituição. Integrante do grupo de pesquisa "Núcleo de Ensino e Pesquisa em História da Educação” da UERJ. Atualmente, realiza pesquisas sobre a História da Educação Brasileira no Império, em especial, sobre os intelectuais que atuaram no cenário educacional desse período.

E-mail: edgleide.clemente@gmail.com

\section{Ivanildo Gomes dos Santos}

Doutor em Educação pelo PPGE-CE da Universidade Federal da Paraíba; mestre em Educação pelo PPGE-CEDU da Universidade Federal de Alagoas; especialista em Administração de Arquivos e Documentação pela Universidade Federal de Alagoas; e graduado em História pela Universidade Federal de Alagoas. Membro do Grupo de Estudo e Pesquisa História da Educação da Paraíba - HISTEDBR/PB.

E-mail: ivanildoeduc@hotmail.com 


\section{Maria das Graças de Loiola Madeira}

Doutora e mestre em Educação pela Universidade Federal do Ceará com estágio pós-doutoral pela Università degli Studi di Firenze; e licenciada em Pedagogia pela Universidade Federal da Paraíba. É professora Associada do Centro de Educação da Universidade Federal de Alagoas; ministra a disciplina Fundamentos Históricos da Educação e da Pedagogia e pesquisa as produções literárias de docentes dos séculos XVIII-XX. Alguns temas estudados: biografias, educação missionária, magistério e literatura, impressos compêndios e instituições educacionais.

E-mail: gloiola@bol.com.br

\section{Mauricéia Ananias}

Doutora e mestre em História da Educação pela Universidade Estadual de Campinas - UNICAMP (2005 e 2000); e graduada em Licenciatura Plena em Filosofia pela Pontifícia Universidade Católica de Campinas - PUCC (1994). Atualmente, é professora Associada do Centro de Educação e membro do Programa de Pós-graduação em Educação da Universidade Federal da Paraíba. Integra os Grupos de pesquisa: História da Educação no Nordeste Oitocentista - GHENO e Estudos e Pesquisas História da Educação da Paraíba - HISTEDBR/PB, ambos radicados na Universidade Federal da Paraíba. Tem experiência na área de Educação, com ênfase em História da Educação, atuando principalmente com temas relacionados à história da educação na Paraíba Imperial, em especial, pesquisando processos de escolarização e a institucionalização da escola pública primária.

E-mail:mauriceia.ananias@gmail.com 


\section{Monica Luise Santos}

Mestre em Educação pelo Programa de Pós-Graduação em Educação Brasileira da Universidade Federal de Alagoas; e graduada em Pedagogia pela Universidade Federal de Alagoas. É professora pública do município de Atalaia - Alagoas. Integrante do grupo de pesquisa História da Educação, Cultura e Literatura. Foi bolsista de Iniciação Científica no projeto de pesquisa "Roteiro de fontes da educação em periódicos de Alagoas: a trajetória da profissionalização e organização docente (1850-1950)", coordenado pela Prof. ${ }^{a}$ Dr. ${ }^{a}$ Maria das Graças de Loiola Madeira.

E-mail: monica.luise08@gmail.com

\section{Regina Brito Mota dos Santos}

Mestranda em Educação pela Universidade Federal da Paraíba (UFPB); e graduada em Pedagogia pela Universidade Federal de Alagoas. É professora da educação básica pela Prefeitura Municipal de Maceió.

E-mail: reginabrito11@hotmail.com

\section{Suzana Lopes de Albuquerque}

É professora do Instituto Federal de Educação de Goiás, Campus Goiânia Oeste, mestre em Educação pela Universidade Federal de Alagoas e doutoranda no programa de Educação na Universidade de São Paulo (USP). É líder do Grupo de pesquisa Panecástica e bolsista PIQS - IFG.

Email:suialopes@hotmail.com 